Thls report wo prepared as an eccount of Government sponoved waik. Notilher the Untred Stotes, nor the Commisalen, nor eny penon ecting on behalf of the Commissions

A. Molkes any warranty of representotion, exprese or inplied, with mapect to the eecuracy, completeness, or usefulnes of the informetion containad in this report, or that the uno of eny information, opporutus, mothod, or process diselesed in this report moy not infringe privately uwned tighthy or

8. Anumes any liabilities with respect to the wo of, or for domages nesulting from the ueo of any Information, apparstus, method, or process disclosed in this report.

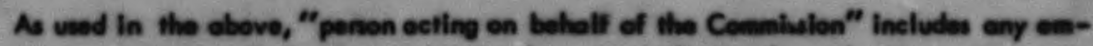
ployse or controctor of the Commistion to the extent that weh employee or econtroctor preparas, hendles or distributes, or provides eceess to, eny informatlon punvent to hls enployment or contrect with the Comminion.

Contract No. W-7405, eng 26

Reactor Bxperimental Engineering Division

\title{
A MANUAL OF
}

HRE CONTROL AND INSTRUMENTATION

L. R. Quarles

W. P. Walker

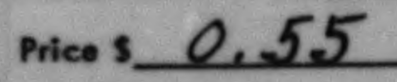

Avoilable from the

Office of Technical Services

Department of Commeree

Woshington 25, D. C.

\section{JAN 231952}

Date Issued CEISSIFICATION CANCELLED DATE MAR 21957 For The Atomic Energy Commistion - 20

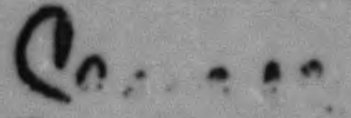
Chiof, Deoiassification Branch

\section{OAK RIDGE NATIONAL LABORATORY}

Operated by

CARBIDE AND CARBON CHEUCCALS DIVISIOA

Union Carbide and Carbon Corporation

Post Office Box $P$

Oak Ridge, Tennessee 
Instrument Index

Table of F1gures

Introduction

React1vity Control

Nuclear Instrumentation

Rod Drive

Process Instruments and Control _.......... 19

Pressurizer Level Control

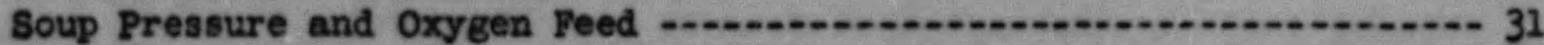

Soup C1rculation and Beat Exchanger .................................... 37

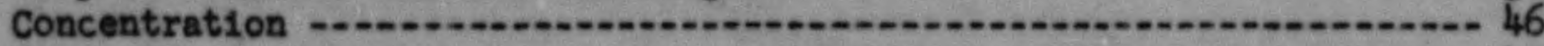

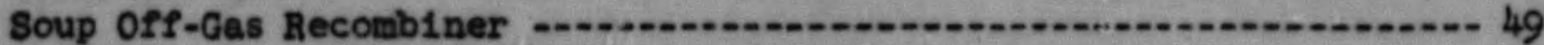

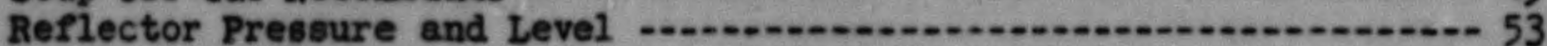

RePlector Temperature

D>0 Soup System

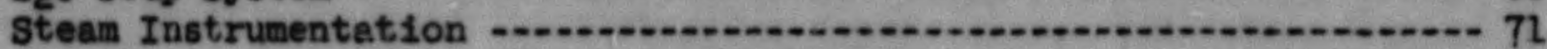

Cold Traps

Alare Annunciator and Mimic Panel

Safety c1rcuit

Typ1cal Operations -... 90

Operation and Loading of the Generator

Conclusion
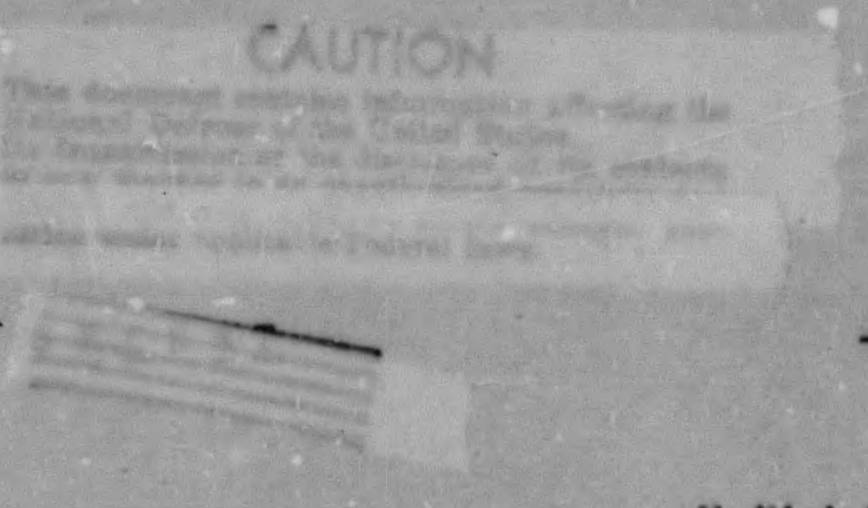


\section{INSTRUMEANY INDEX}

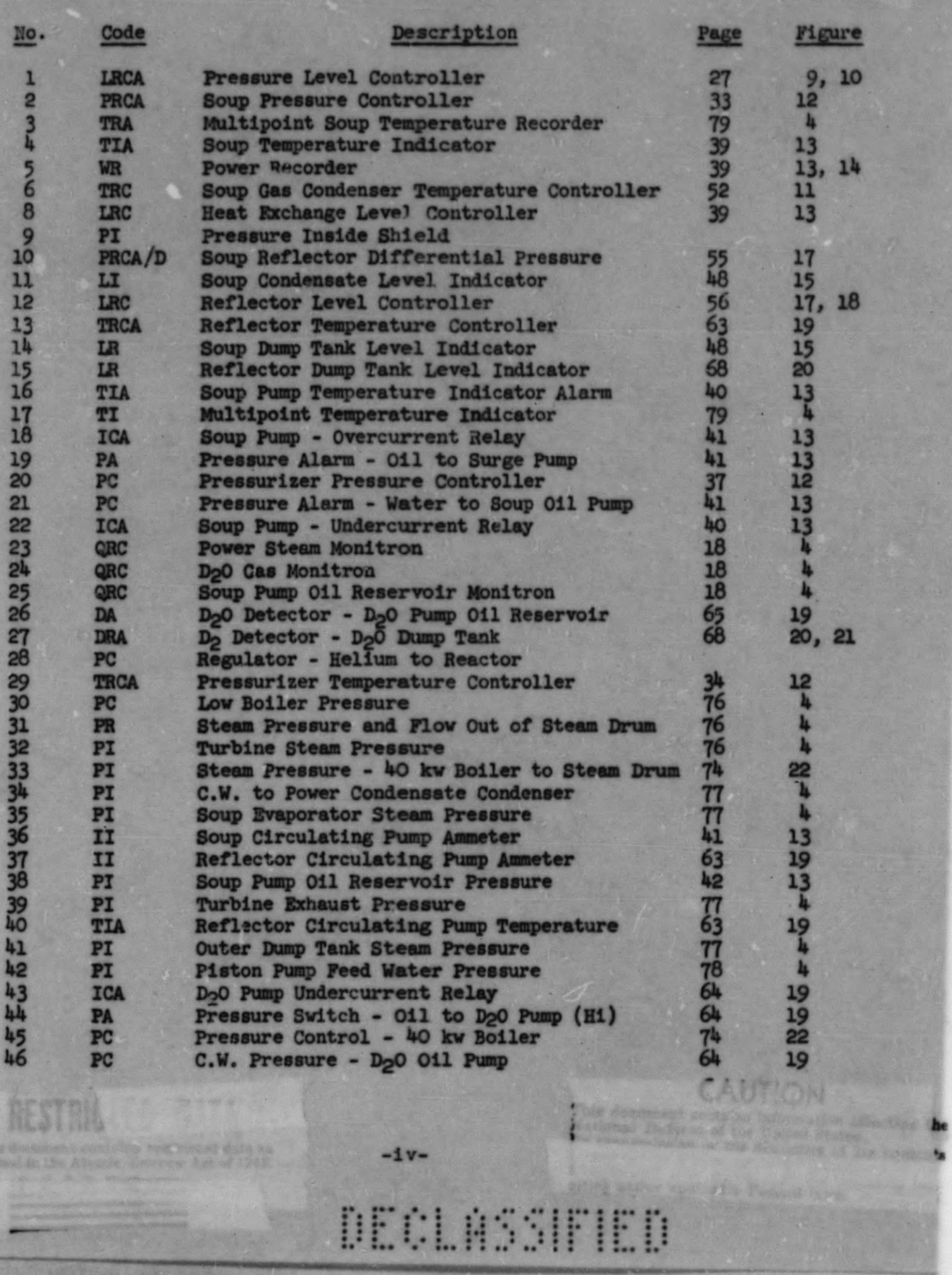




\section{IMSTRUMGOVI INDEXX (CONTINUED)}

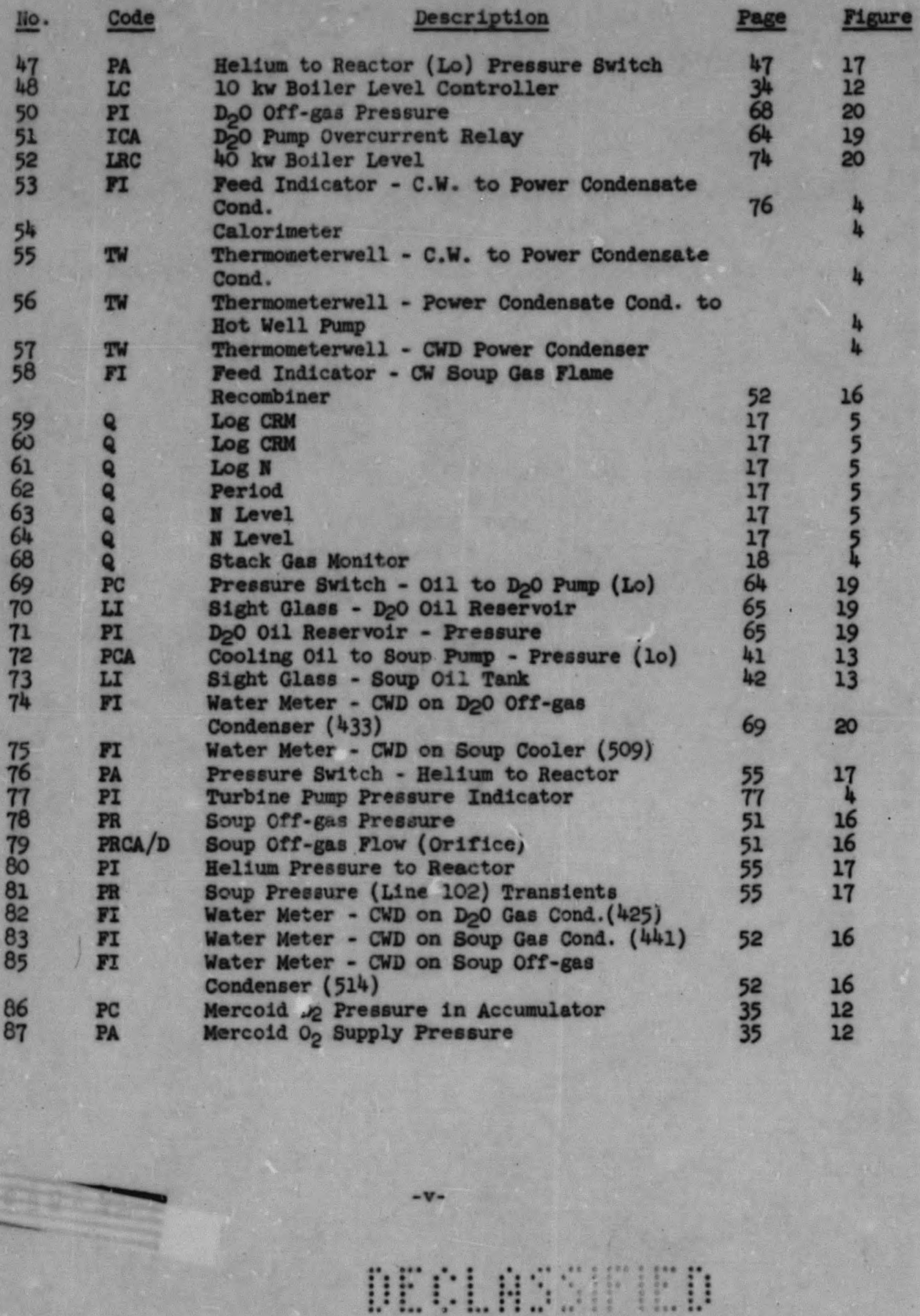


Figure 1 rigure 2 Figree 3 Figure 4 Figure 5 Figure 6 Figure 7 Figure 8 Figure 9 Figure 10 Figure 11-A Figure 11-B F1gure 11-C Figure 11-D Pigure 12 Figure 13 Figure 14 Figure 15 Figure 16 Figure 17 Figure 18 Figure 19 Figure 20 Figure 21 Figure 22 Figure 23 Figure 24 Figure 25 Pigure 26 Figure 27
- Control Room -

- Instrument Panels -

- Console - _.

- Flow Sheet -

- Muclear Instrumentation -

- Simplified Fuel System - -

- Concentration Rate - -

- Reflector System -

- Pressurizer Level _-_._-

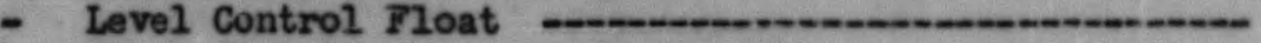

- Input Cirevit -

- Input Circuit _-

- Input Circuit -

- Input circuit

- Pressurizer

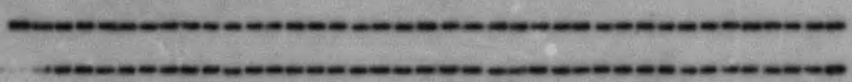

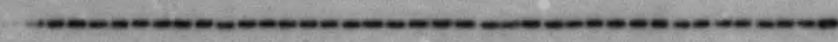

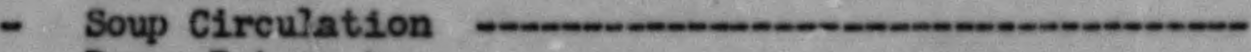

- Power Integrator -...2_-_._-

- Weigh Systems _-

- Soup Off-Gas - -

- Reflector - -

- Reflector Level _.......

- D20 Circulation -

- D20 Durp System -

- D20 Detector -

- Lo notier -

- Cold Traps - -

- Alarm Anm veiator _..._- 81

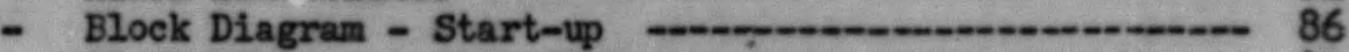

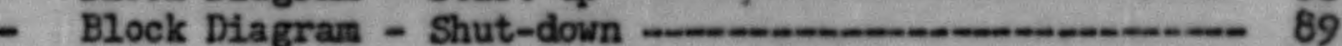

- Safety Circuit _._- 91

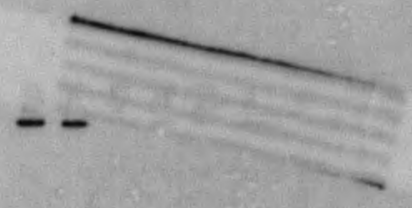


Introduction

The controls for the Homogeneous Reactor Experiment may be divided 1nto three principal groups:

1. Reactor

2. Process or auxiliary

3. Power generation.

Wh1le these necessarily overlap somewhat because of the coupling between the various functions of the experiment, this classiflcation does designate the primary functions of the controls.

Since the project is an experiment designed to furnish data which will ald in designing future large-scale homogeneous power-producing reactors there are numerous instruments and control features which would ordinarily be omitted. For example, the reactivity may be controlled in several ways so the most desirable method may be determined by operating experience.

The operating controls and instruments have been grouped to minimize the number of operat1ng personnel for routine operation. Although 1t is real1zed that during experimental runs, several englneers will be needed, a two-man crew should be able to handle the entire plant for regular operation. All remote valve operators, automatic controllers, and operating instruments are located in the control room and are arranged according to frequency of use.

The general layout of the control room is shown in Figure 1. The console has all the manual controls which must be handed by the operator - during start-up or at frequent intervals auring operation. Control stations

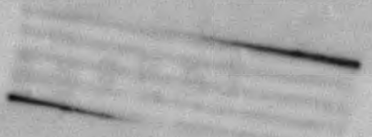




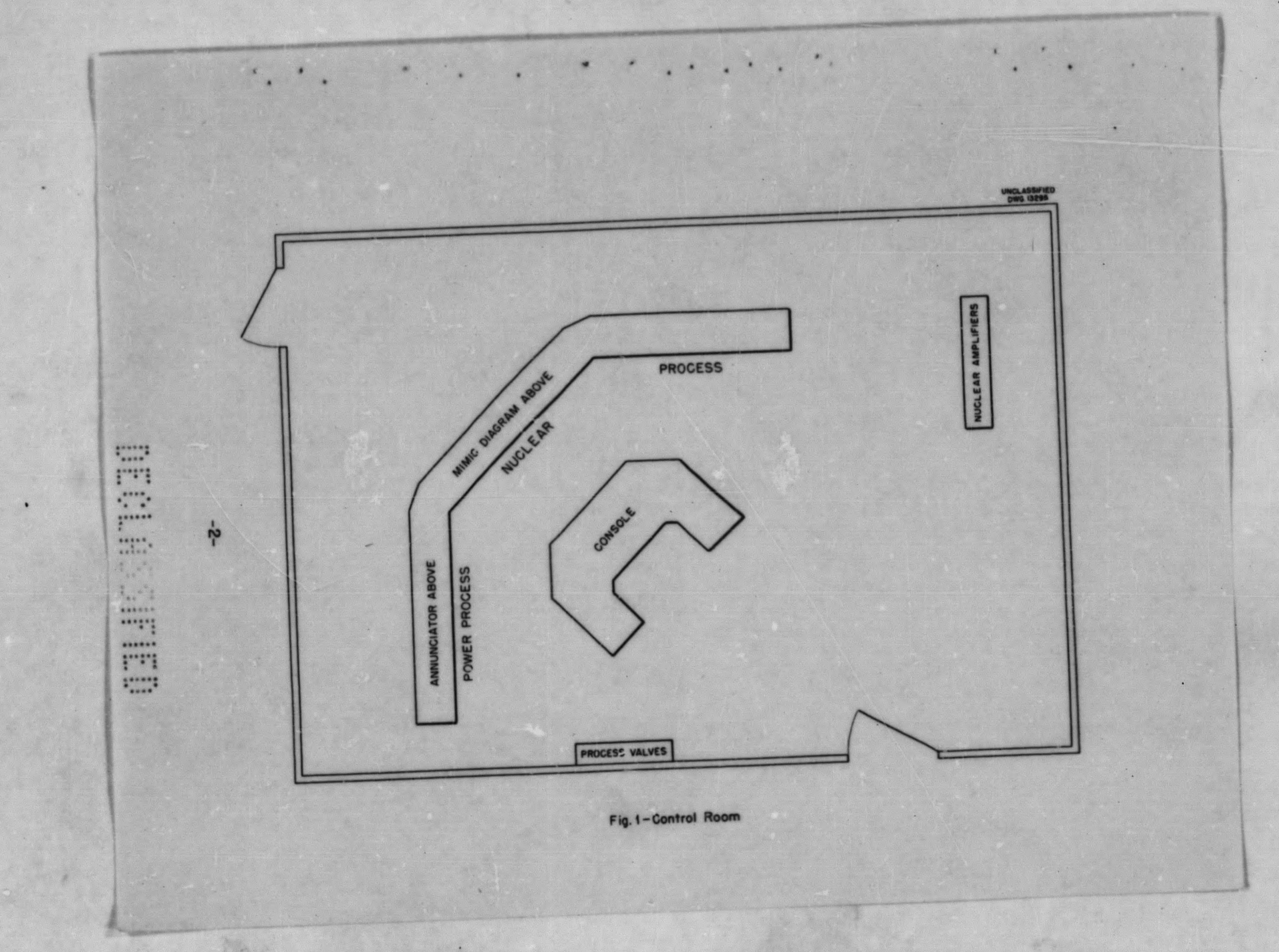


for pneumatic valves which need to be changed infrequently are grouped on a panel located to one side so that the operator can check controller position and air pressure without leaving his seat. Sultches for the various motors and electric heaters which do not require frequent changes are mounted on the left hand panel board. Thus the operator or his assistant may set up the correct valve positions and operation of auxiliaries before start-up and then the operator can bring the reactor to power, gynchronlze the generator on the line and continue operation from the control console.

The panel board instruments are grouped roughly according to general classification and according to their importance in operation. Thus the instruments indicating reactivity (CRM, $10 \mathrm{~N}$, rod position, reflector level, etc.) are on the center panel directly in front of the operator. The instruments assoclated with power generation are on the panel at the operator's left and the process instruments on the one to h1s right. The detalled panel layout is shown in Figure 2. The console, shown in Figure 3, has the controls grouped in a similar manner. Principal reactor controls are at the operator's right, with less critical process controls at the extreme right, while the steam and electrical power controls are on the left.

In addition to the supervision provided by the instruments, the various alarme are reglstered or a two-light annunciator panel and the position of all remote-operation valves is shown on a mimic panel. The alarms give an audible signal, which may be stopped by the operator, and give two visual signals on the annunciator panel. The first of the visual signals will clear autonatically when the fault clears, but the second one will continue unt1l reset by the operator, thereby enabling him to spot and record even a momentary fualt. A

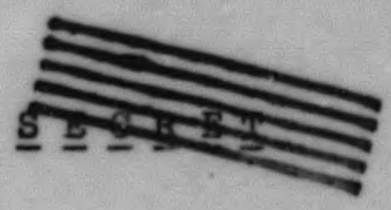




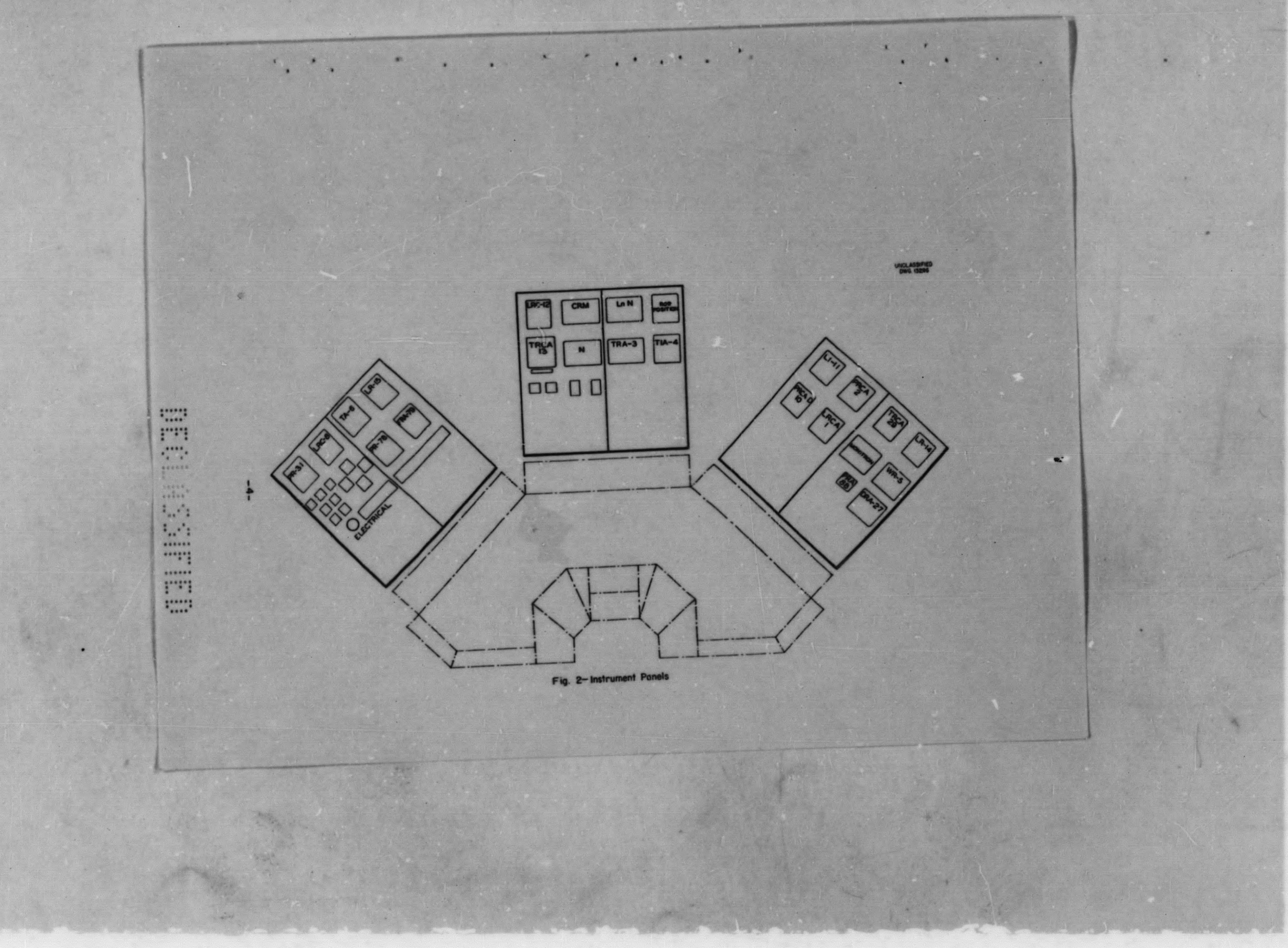




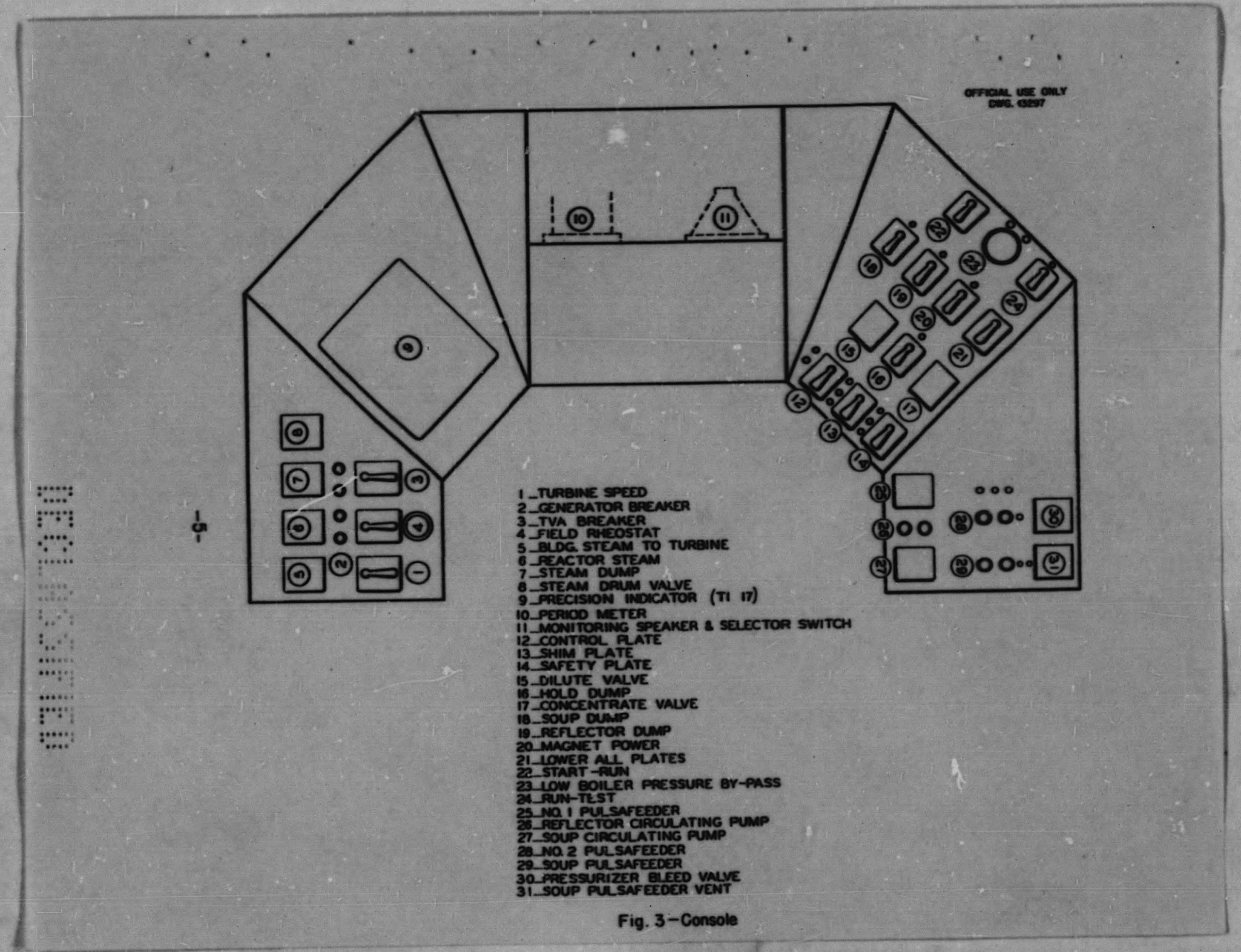


mimic pahel mounted above the center panel board is a simplified flow diagram showing principal piping and valves. The position of each valve is indicated on this diagram by colored lights, thus enabling the operator to check the system valving at a glance.

The flow sheet shown in Figure 4 shows all instrumentation except the reactor nuclear 1nstruments and the building monitors. The nuclear instrumentation consisting of standard components is shown in the block diagram of Figure 5. The controls will be discussed in a general manner before considering the detalled operation of each instrument or control.

Basically, the HRE consists of three major system components - soup or fuel, reflector, and power generation. These may be considered by reference, to Figure 4. The soup in the critical volume and heat extraction loop Is maintained at a high pressure (design value of $1000 \mathrm{psi}$ ) by a steam pressur1zer located in the upper part of the reactor assembly. The remainder of the soup system consists of the dump tanks, concentrating components, and gas handling components. The reflector and 1ts heat extracting loop are operated at a pressure slightly above that of the soup. The dump tanks and off-gas equipment complete the reflector part. The power generation equipment is falrly standard from the heat exchanger on. The valving is somewhat compl1cated by the need for introducing steam from the builaing boller for start-up heating and experimental work.

The nuclear instrumentation shown in Flgure 5 is an adaptation of the "MIR" Instruments. Two fission chambers are connected to counting rate

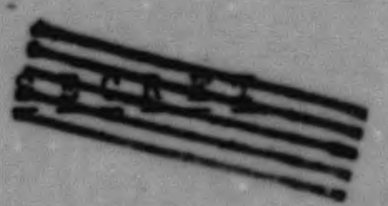

$-6-$ 


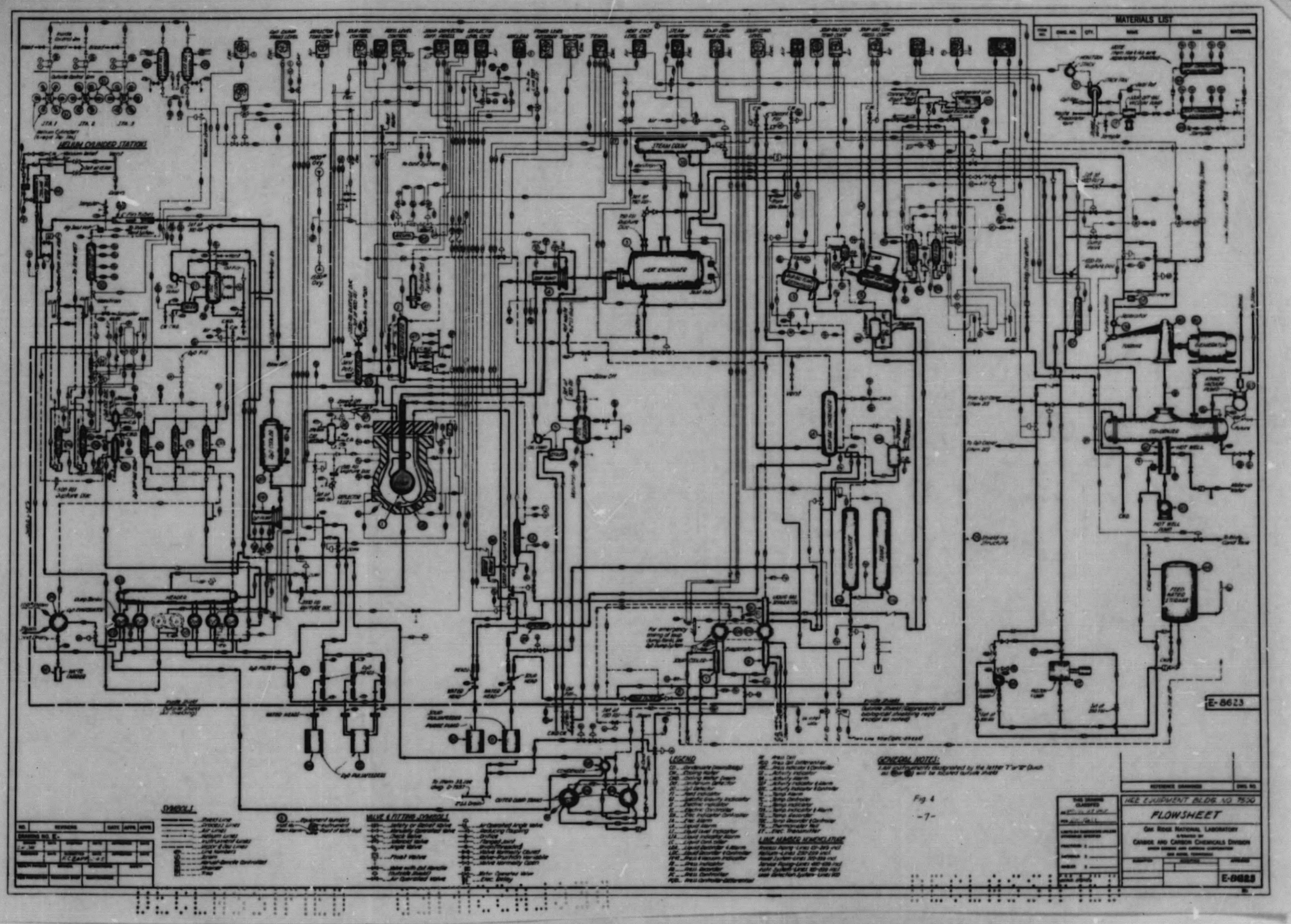




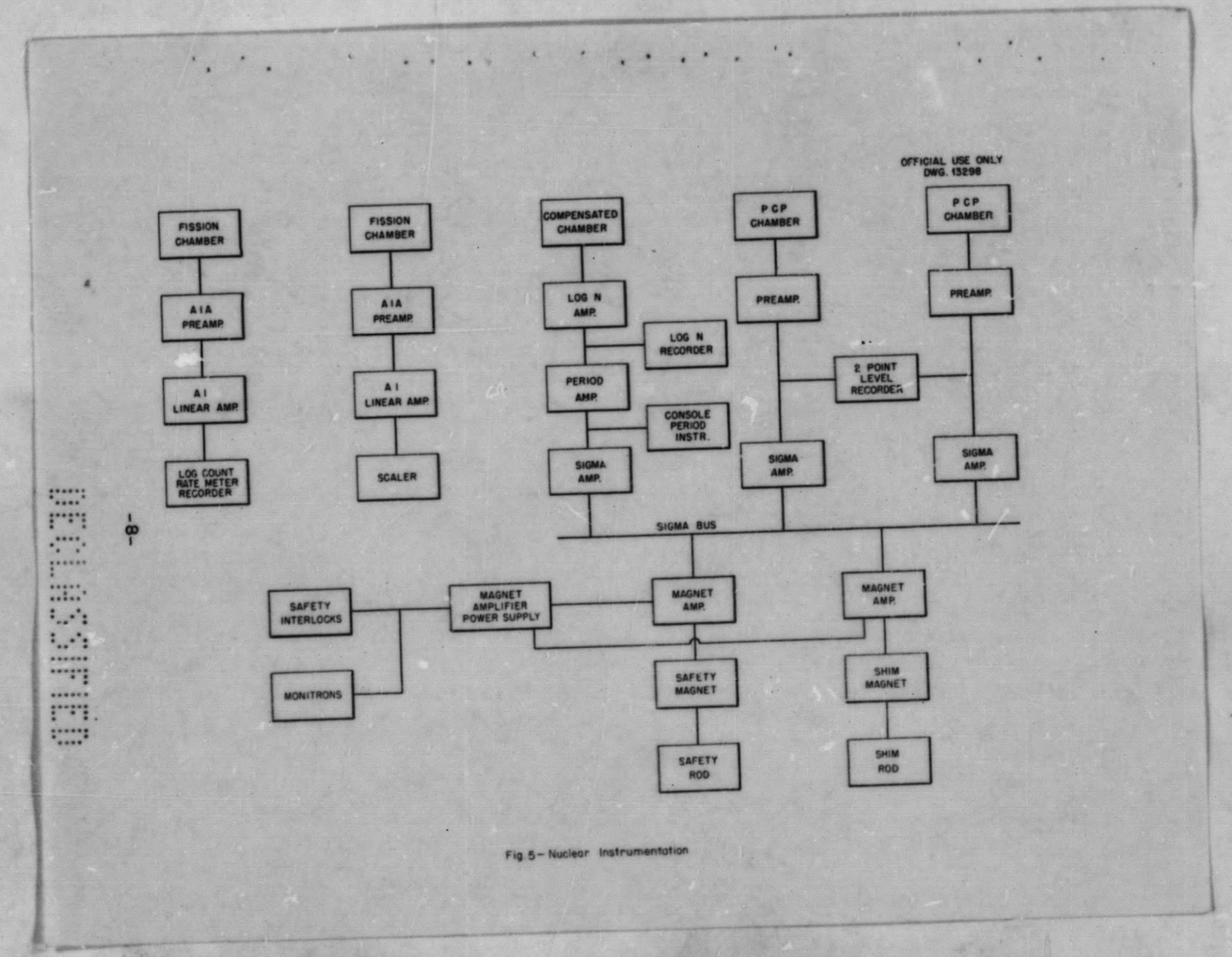


meters and a compensated ion chamber drives both a $\log \mathrm{N}$ and a period meter. Two PCP boron chambers are connected to a two point level recorder and to the conventional scram circuit. Several monitoring chambers are located on critical points to detect soup leaks, one on either side of the heat exchanger, one on the soup c1rculating pump cooling o11 system, one on the $\mathrm{D}_{2} \mathrm{O}$ off-gas system, and one on the stack.

The 1nstruments and controls on the power generation equipment are standard. On the stean side these include main heat exchanger water level, steam flow, and a throttling calorimeter. The electrical instruments are the usual voltmeters, ammeters, kllowattmeter, power factor meter, frequency meter, and synchroscope.

\section{$\underline{\text { Reactivity Control }}$}

The HRE has a high negative temperature coefficient of reactivity $\left(.0011 \delta \mathrm{k} /{ }^{\circ} \mathrm{C}\right.$, ORNL-730) so $1 \mathrm{t}$ is inherently self stab111zing, and hence does not require a servo system on the regulating rod. Any slight change in reactivity which would require servo correction in a low temperature coefficient reactor merely causes a small change in temperature of the HRB. This large temperature coefficient tends to make the reactor automaticaliy respond to changes in power demand. A change of steam demand will produce a correspondIng change in soup cooling in the heat exchanger so the soup temperature w11 drop for an increesed steam demand or rise for a decreased demand. This temperature change produces a change of $k$ so the power changes to meet the new demand and the reactor levels off at the new power and the same average temperature (all other $k$ controls having been left fixed).
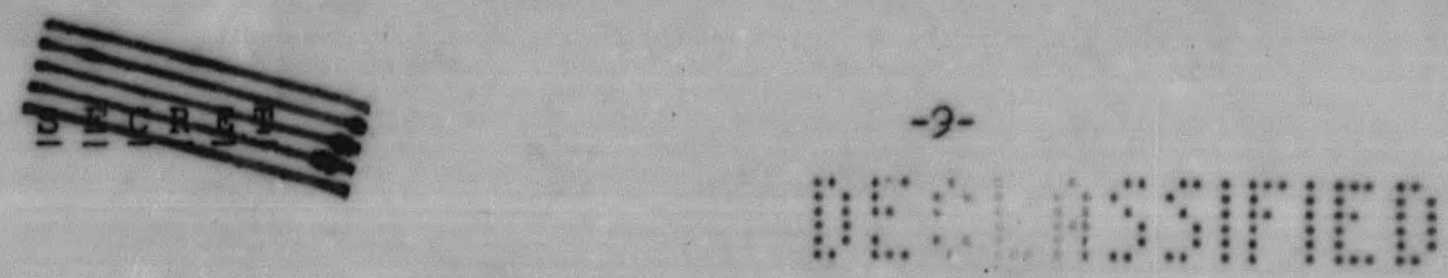
There are three methods provided for varying the reactivity - concentration of fuel solution, reflector level, and rods. These are interlocked so $k$ cen be 1 ncreased by only one at a time. The reaction of the power demand through the temperature coefflcient might be considered a fourth method.

Concentration control may be explained by reference to Figure 6 , which shows a simplified version of the soup system. The component numbers correspond to those of the complete flow sheet of F1gure 4. Soup from the dump tank is pumped Into the core by the pulsafeeder and let down through the valve operated by a level controller on the pressurizer. Thus there is a cont1nuous c1rculation at approximately $1.5 \mathrm{gpm}$ between core and dump tanks. The c1rculating pumps give a flow of $100 \mathrm{gpm}$ tiurough the core-heat exchanger loop. The steam evaporator on the dump tank operates continuously, evaporating water from the soup in the tank. This resulting steam is condensed and if the concentrate valve is open the condensate returns to the dump tank. There 18 no net change of concentration in the system under this condition. If bot! the concentrate and dilute valves are closed the condensate is collected in the condensate tanks and the soup in the dump tanks becomes nore concentrated. Th1s in turn results in the core soup becoming more concentrated since there 1s continuous circulation. To lower concentration the dilute valve is opened, dumping the condensate into the pulsefeeder 1ntake line and hence Elving almost pure water Into the core. Both concentrate and dilute valves are throttling valves controlled from the console by the operator, so the rate of concentration or allution may be adjusted by the operator.

The maximum rates of response to concentration control may be readily computed if initial and final states are known. For dilution, a 


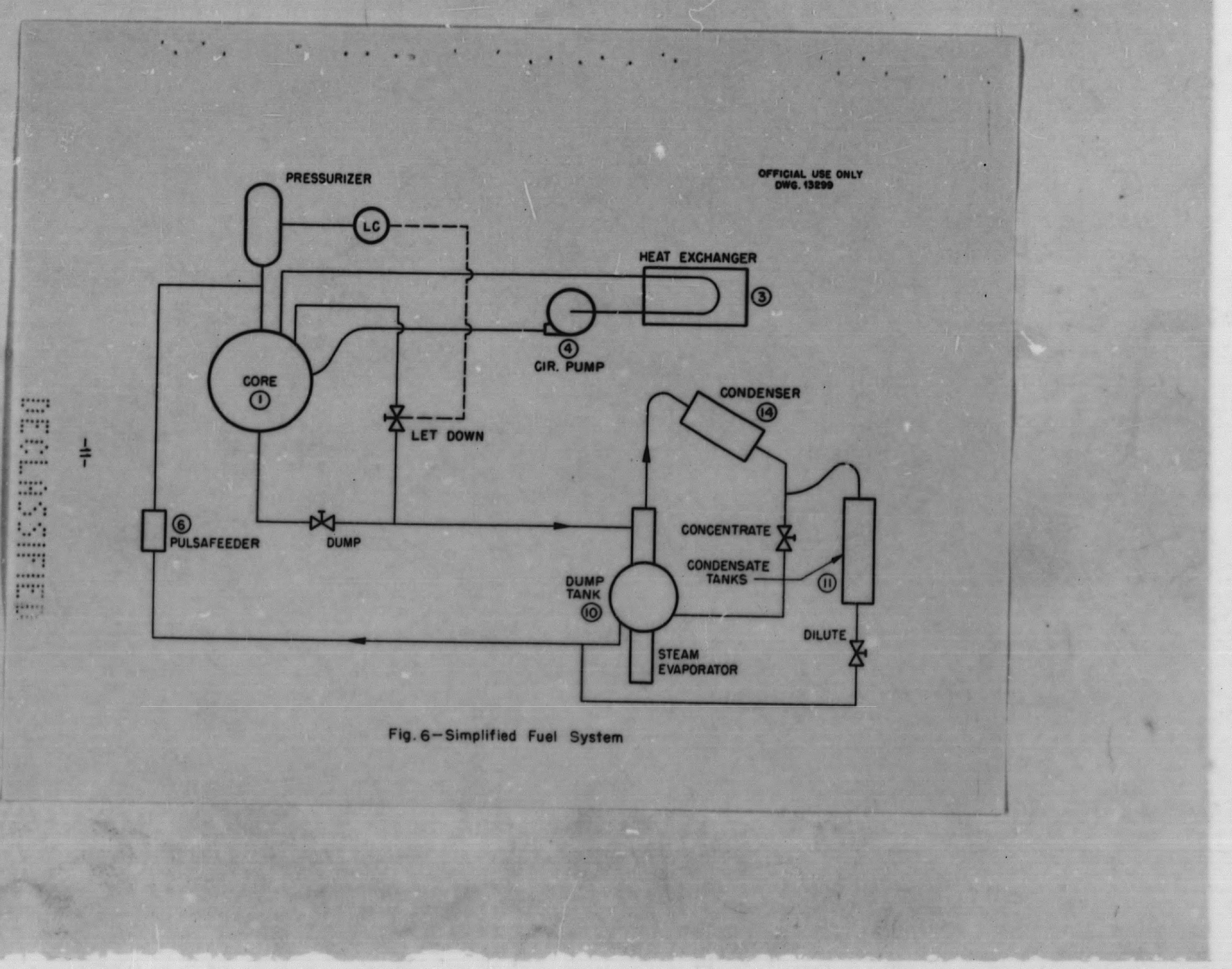


fair approximation is to assume the dilution vaive is fully open and the relative impedances to flow through the condensate line and the soup filter are such that practically pure vater 1.5 pumped into the core by the pulsafeeder. Then,

$$
\frac{d m_{c}}{d t}=-c_{c} p=-\frac{m_{c}}{V} \rho
$$

where

$$
\begin{aligned}
& m_{c}=\text { uranium in the core } \\
& c_{c}=\text { concentration in core } \\
& f=\text { pumping rete } \\
& V=\text { volume of core system } \approx 75 \text { i1ters. }
\end{aligned}
$$

This Biver

or

$$
\begin{aligned}
& m_{c}=M_{0} e^{-f t / v} \\
& c_{c}=C_{0} e^{-f t / v}
\end{aligned}
$$

Typical values are:

$$
\begin{aligned}
& \text { Safe concentration at } 20^{\circ} \mathrm{c}, \mathrm{C}_{\mathrm{c}}=20 \mathrm{gm} / 1 \\
& \text { Critical concentration, } C_{0}=35 \mathrm{gm} / 1 \\
& \text { Pumping rate, } P=5.61 / \mathrm{min} \text {. }
\end{aligned}
$$

The ainimum time to dilute from the critical concentration to a safe volume 18:

$$
\begin{aligned}
& 20=35 e^{-\frac{5.6}{75} t} \\
& t=7.5 \text { minutes. }
\end{aligned}
$$

The soup in the core system should siways be reduced to a safe con. centration on sny shutdown for walch the reflector $1 \mathrm{~s}$ dumped. Othe.wise the soup may cool to a relatively low temperature and become critical upor

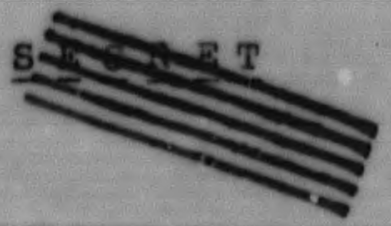

$-12-$

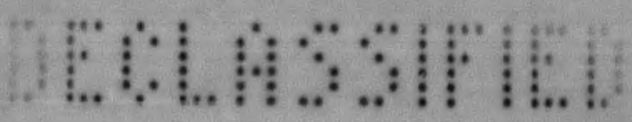


restarting before the temperature interlocks function. The soup is automaticaliy diluted when-1t is dumped.

The equations for soup concentration may be set up by a consideration of the material balance. With the concentration and allution valves closed we can write:

$$
\begin{aligned}
& v \frac{d C_{C}}{d t}=f C_{D}-r C_{C} \\
& M=v C_{C}+\left(v_{D}-B t\right) C_{D}
\end{aligned}
$$

where

$C_{D}=$ dump system concentration

$\mathrm{V}_{\mathrm{D}}=$ dump system volume

$t=t i m e$

B = evaporation rate

$M=$ total uranium in the system, assiumed as $4 \mathrm{~kg}$.

Then,

$$
\begin{aligned}
& C_{D}=\frac{M-v_{C}}{V_{D}-B t} \\
& \frac{d C_{C}}{d t}+\frac{{ }^{2} C_{C}}{V} 1+\frac{V}{V_{D}-B t}=\frac{f}{v} \frac{M}{V_{D}-B t}
\end{aligned}
$$

The solution of this equation for various values of the parameters is presented in the form of curves in Figure 7 .

The relation between concentration and $k$ has been computed and is Given as Figure II-1, aRWL-730. The concentration 1s measured indirectly by weighing the water in the condensate tanks. Knowing the initial charge of 


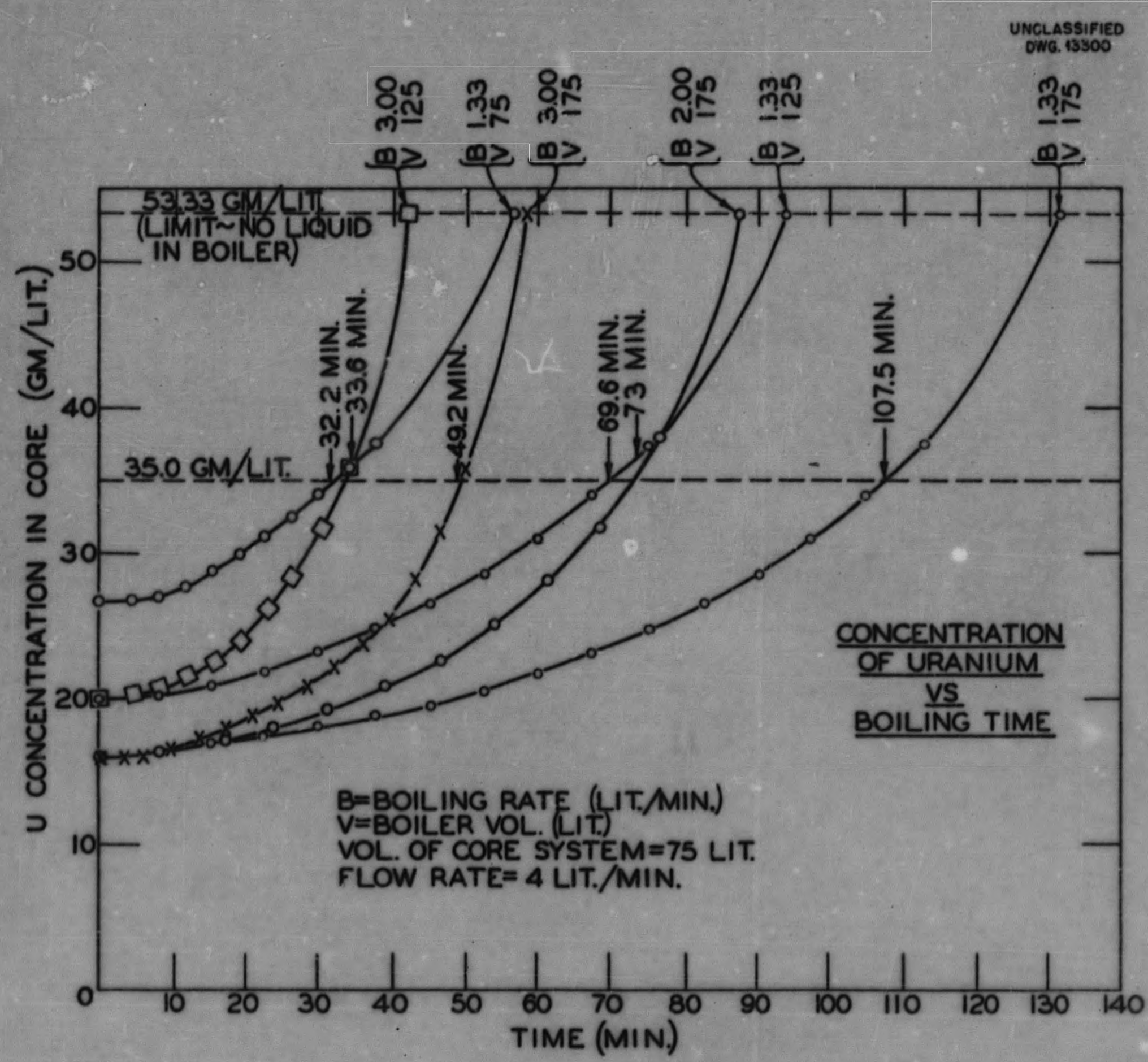

Fig. 7-Concentration Rate

$-14-$ 
water and urany 1 sulphate the concentration is readily determined from the Ser hold-up so the velgh instrument may be calibrated in terms of concentration. As a check on the entire soup systen, as well as the concentration instrument, the soup in the dump tanks is also weighed. This method of decermining concentration 1s not an absolute determination since it cannot take into account any partial precipitation and hold-up of fuel in the system, nor is it capable of giving rafid measurements of concentration in the core 1tself. Fortunately, hovever, the reactor can be operated safely without knowing the values accurately.

The basic reflector flow sheet is given in Figure $8 . D_{2} \mathrm{O}$ is pumped Into the reflector from the dump tank by means of pulsafeeder pumps. This vater 1s c1rculated through the heat exchanger where 1ts heat is extracted to preheat the feed water of the soup heat exchanger. Reflector level is maintained by a level controller by appropriate operation of the pulsafeeder punp and letdown valve. Any deslred level from half full to full may be selected by the operator. Since the safety plates are not effective unless immersed in the $\mathrm{D}_{2} \mathrm{O}$, the reactor cannot be operated w1th less than half full reflector. Results presented in ORWL-730 indicate the reflector controls approximately $26 \% k_{\text {eff }}$.

The control rods or plates cons1st of three sets; one of $2.5 \% \frac{\sigma_{\mathrm{K}}}{\mathrm{k}}$ used as a safety; one of $2.5 \%$ used as a shim; and the third having $0.7 \%$ used as a regulating rod. These rods may be ralsed or lowered by constant speed drives rcquiring two minutes for full travel one way, thereby giving a maximum $\sigma^{\prime} \mathrm{k} / \mathrm{k}$ rate of $1.3 \% / \mathrm{minute}$. The sh1m and safety rods are suspended from the drive mechaniam with electromagnets so they may be released very quickly. The release time of the magnets $1 \mathrm{~s} \sim 7$ milliseconds, and the rods are spring

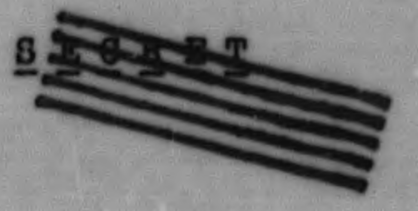




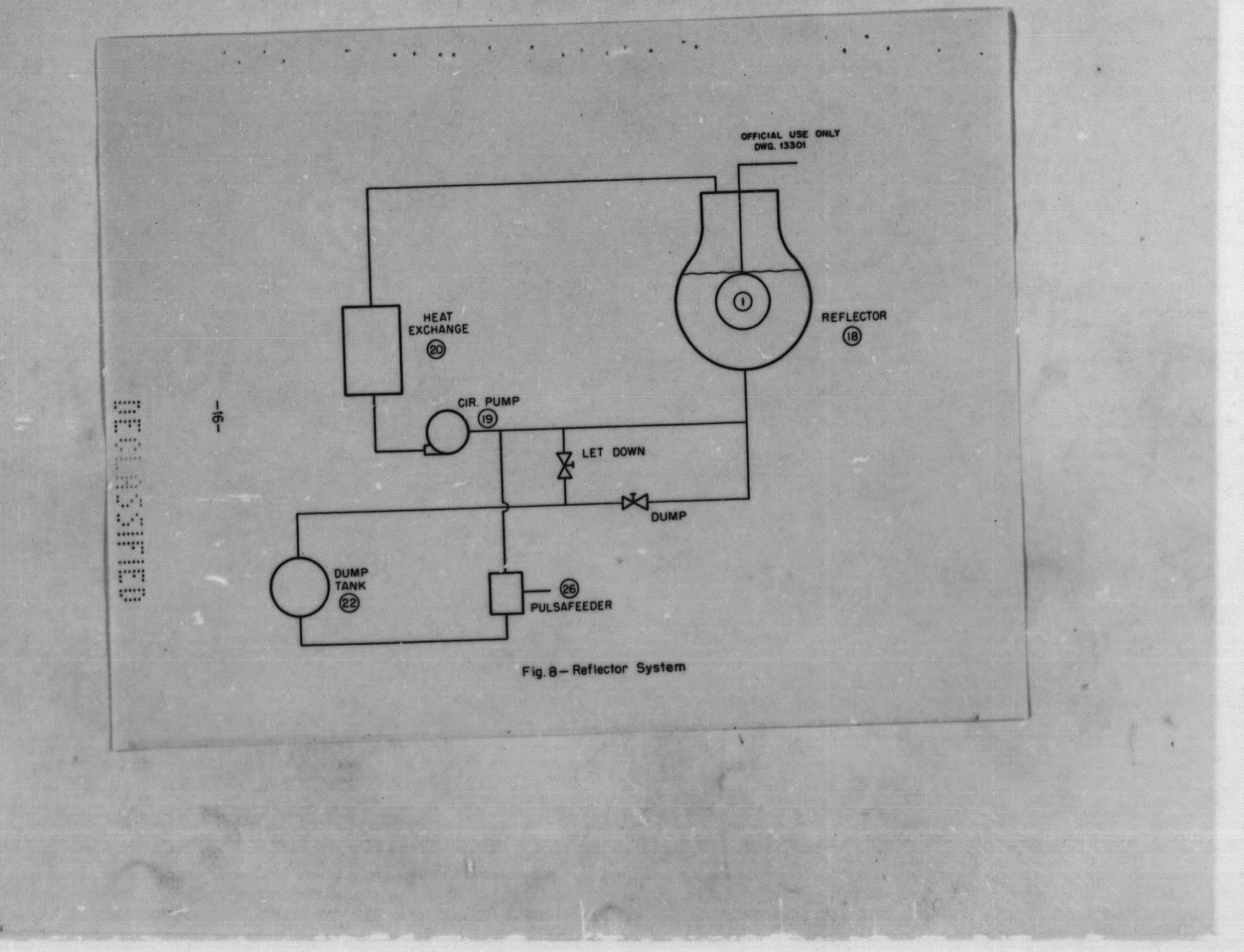


loaded to produce an initial acceleration of $5 \mathrm{~g}$. On an emergency drop the rods reach one-third of their totel insertion in $\sim 50$ milliseconds.

\section{Nuclear Instrumentation}

The nuclear instrumentation consists basically of the var1ous chambers and associated cfrcuits for mon1toring the reactor proper and several monitrons monitoring componente. S1x thimbles are provided through the shielding and reflector so the neutron flux leaving the core may be determined with suitable chambers. W1th the exception of the period amplifier all components of these c1rcults are "standard" units as used for the MCR (ORINL-963), and so w11l not be discussed in detall.

Two f1seion chambers and associated A-1A pre-amplifiers and A-1 amplifiers are provided for counting rate measurements from source level $\left(\sim 10^{-11} \mathrm{~N}_{\mathrm{F}}\right)$ to $\sim 10^{-6} \mathrm{~N}_{\mathrm{F}}$. One of these will be connected to a Brown strip recorder for a $\log \mathrm{CRM}$ record, while the other will be connected to a scaler. The scaler and recorder may be 1nterchanged by switches.

A compensated chamber is used in conjunction with a $\log$ amplifier end period amplifier to give Log $\mathbf{N}$ and period measurements and safety control. The Log $\mathbf{N}$ instrument is a Brown recorder covering the range $10^{-6} \mathrm{~N}_{\boldsymbol{F}}$ to $\mathrm{N}_{\mathbf{P}}$. The period instrument is an indicating instrument mounted on the console. It gives a usable indication at a flux of $\sim 10^{-7} \mathrm{~N}_{\mathrm{p}}$. Mathematicel ansiysis or the HRE (ORWL-730) has Indicated that very rap1d, positive pover surges with fast positive periods followed by a negative period vill probably occur. It seems 


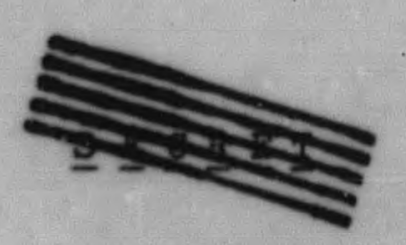

advisable, therefore, to modify the MIR period amplifier to include a negative period scram. Thus, if the positive surge does not last long enough to permit the safeties to act, the following negative period will scram the reactor and prevent an osc1llation build-up. The negative period scram will also protect the reactor against a continued rap1d rise of temperature since such a rise puts the reactor on a negative period.

The two PCP boron chambers and their amplifiers serve as rlux instruments and safeties at the upper flux levels, 10-3 $\mathbb{N}_{F}$ to $\mathbb{N}_{F}$. The safety signal 1s fed from both to the sigma bus, while the fiux level is recorded on a twopoint Brown recorder. Th1s instrument is equipped with a second slide wire mechanically connected to the balancing motor. This slide wire is used as the load of a watt-hour meter so the meter register is a record of nvt for the reactor.

The monitrons supervising reactor components are remote chamber units with the chambers located at various critical points. The outputs are recorded on a six-point Brown str1p chart recorder and the emergency levels actuate the appropriste contacts in the safety c1rcuit as discussed below. QRC-23 and -26 monitor the heat exchanger for soup leaks. In addition to shutting the reactor down, these close valves $316 \mathrm{~A}, 316 \mathrm{~B}, 330,323$, and 321 , thus 1solating the heat exchanger. The stean drum provides enough stean hold-up ( $\sim 4$ seconds) to permit valve $3 i 6 \mathrm{~A}$, a quick-closing unit, to close before active stean can get outside the shield. WC-24 monitors the $D_{2} \mathrm{C}$ orf-gas and is tied into the safety c1rcult. QRC-25 checks the soup circulating punp oil for a soup leak and in sn emergency dumps the soup. QRC-68 provides over-all steck supervision.

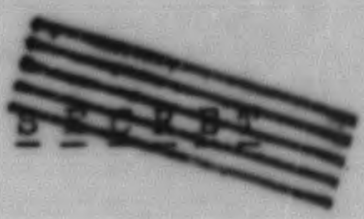

$-18$.

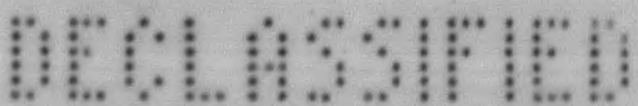


The chambers which are located inside the shield are lead and boral shielded to reduce the background noise so maximum sensitivity to leaks may be realized.

Rod Drive

The drive mechanisms for the three rods or plates are identical, but the method of holding the rods differs. The drive is a three-phase squirrel cage motor geared to s lead screw. The rod position indicator consists of a reciprocating magnet inside the pressure thimble, a magnetically operated switch on the outside of the thimble, and a stepping relay driven panel board indicator. The magnet is moved back and forth by a cam on the lead screx shaft so it operates the outside switch once each revolution. This switch in turn pulses a steppine relay mechanism arranged to drive a drum in the panel instrument. The drum moves a colored tape across the face of the instrrument to Indicate the position or the rod. This gives the rod location to $0.9 \%$ of its full travel, or for the control rod to $.006 \%$ o $\mathrm{k}_{\mathrm{eff}}$. The zero position may be checked by the 1imtt switch signals at either end of the travel.

\section{Process Instruments and Control}

The operation of the instruments and controls will be discussed in groups on a functionel basis rather than individually. Table 1 summarizes the control valve date. The aumerical designetion of instruments is rather arbitirary, so the order of this discussion is not necessarily that of instrument aumbers, tut they are listed in numerital order in the instrument index. The letter code used with tine instruments gives the function of the 1 nstrument as follows: 


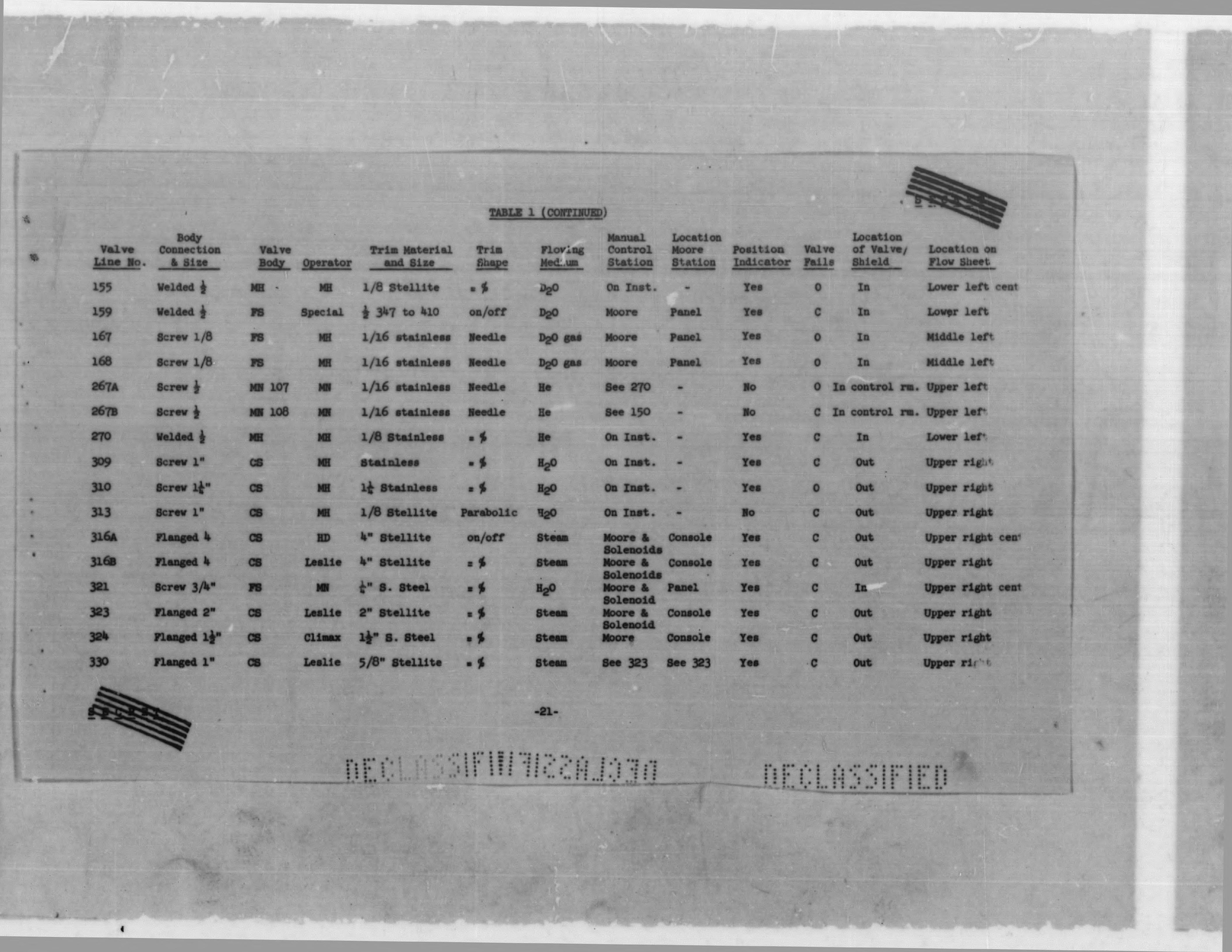


TABLE 1 (COMRINUKD)

\begin{tabular}{|c|c|c|c|c|c|c|c|c|c|c|c|c|}
\hline $\begin{array}{l}\text { Valve } \\
\text { Line No. }\end{array}$ & $\begin{array}{c}\text { Body } \\
\text { Connecttion } \\
\text { \& size } \\
\end{array}$ & $\begin{array}{l}\text { Valve } \\
\text { Body. }\end{array}$ & Operator & $\begin{array}{c}\text { Trim Material } \\
\text { and size } \\
\end{array}$ & $\begin{array}{l}\text { Trim } \\
\text { Shape }\end{array}$ & $\begin{array}{l}\text { Fowing } \\
\text { Medius } \\
\end{array}$ & $\begin{array}{l}\text { Manual } \\
\text { Control } \\
\text { Stat1on } \\
\end{array}$ & $\begin{array}{l}\text { Location } \\
\text { Moore } \\
\text { Station } \\
\end{array}$ & $\begin{array}{l}\text { Position } \\
\text { Ind1 cetor } \\
\end{array}$ & $\begin{array}{l}\text { Valve } \\
\text { Fails } \\
\end{array}$ & $\begin{array}{l}\text { Location } \\
\text { of Val ve/ } \\
\text { Shield } \\
\end{array}$ & $\begin{array}{l}\text { Location on } \\
\text { Nlow Sheet }\end{array}$ \\
\hline 407 & Screw 3 & MH & MH & Butterfly & & $\mathrm{H}_{2} \mathrm{O}$ & & & Yes & 0 & out & Upper left \\
\hline 438 & Screw & Men 37 's & Ma & Sta:nless & v-port & $\mathrm{H}_{2} \mathrm{O}$ & On Inst. & - & Yes & 0 & out & Upper right cent. \\
\hline 440 & $\begin{array}{l}\text { Serew } \frac{1}{2} \text { or } \\
3 / 4\end{array}$ & vav $37^{\prime}$ s & m & Stainless & v-port & $\mathrm{H}_{2} \mathrm{O}$ & On Inst. & - & No & 0 & out & Upper right cent. \\
\hline 507 & Screw & val 37 's & ves & Stainless & V-port & $\mathrm{H}_{2} \mathrm{O}$ & On Inst. & - & No & 0 & Out & Upper right cent. \\
\hline 347 & Screw $3 / 4 "$ & MH & MII & 1/2" 8. Stee1 & $=\$$ & $\mathrm{H}_{2} \mathrm{O}$ & See 316B & - & \$o & 0 & out & Center right \\
\hline
\end{tabular}

Valves which are located in high flux regions are operated through alr relays located in the $D_{2} 0$ compartment to prevent release of radoactive argon in the control room.

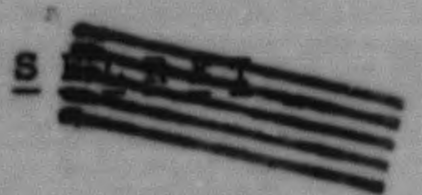

$-22-$ 


\section{First Letter}

$$
\begin{aligned}
& \text { D - Deuterium } \\
& \text { F - Flow } \\
& \text { C - Specilic gravity } \\
& \text { I - Electrical } \\
& \text { L - Level } \\
& \text { P - Pressure } \\
& \text { Q - Activity } \\
& \text { T - Temperature } \\
& \text { W - Power }
\end{aligned}
$$

\section{Fo1lowing Letters}

$$
\begin{aligned}
& \text { A - Alerm, visual and/or audible } \\
& \text { C - Controller } \\
& \text { /D - Differential } \\
& \text { I - Indicator } \\
& \text { R - Recorder } \\
& \text { Z - Integrator }
\end{aligned}
$$

For sensing elements, TC indicates a thermocouple and PE a pressure element. Detalled data on verious instruments are given in Tables 2-12. Vaives are numbered according to the line in which they are located, letters A, B, etc., being used when a line contains more than one control valve.

The response times of the instruments and valves are not given, since In most cases these will be adjusted in the field for satisfactory control. In general, the Foxboro instruments can be adjusted for full-scale responses ranging from 1 to 12 seconds by changing the ofl used. Brown strip chart instruments

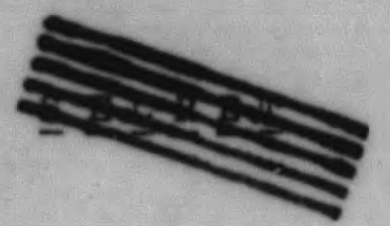




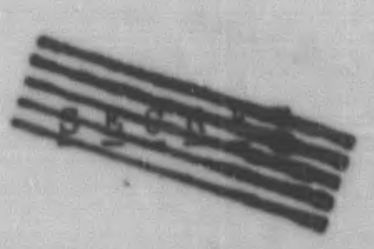

normally have a response time of 4.5 seconds, while the circular chart instruments have a response time of 12 seconds. Valve operating time may be adJusted from approximately 2 to 20 seconds by using positioners and boosters. Where emergency conditions require rapid opening or closing of a val ve, a solenoid valve located near the main valve is used to control the pneumatic operator, thereby eliminating the delay of a long alr line.

\section{Pressurizer Level Control}

This control is shown schenatically in Figure 9, and the instrument date is summarized in Table 2 . The notation used in this figure is common to all of the control drawings of this type. Line numbers and major component numbers are the same as In Figure 4; air lines are Indicated by " $A$ " and electrical connections by " $B$." The wavy breaks in various lines symbolize passage through the shield. Blecţrical Junction boxes are shown as squares with a letter and one or more numbers, the letter referring to the box designation and the number to the particular terminals within the box.

The level control depends upon detecting a change of level in the pressurizer by means of a restrained float in a side chamber. Th1s float Is a section of stainless steel pipe, capped at both ends and supported by two rods as shown in F1gure 10. Th1s construction meets the various specifications for a sensing element at this point in the system - stainless steel for parts contacting 11quid, high pressure operation, no dead ends wh1ch might be difficult to clear of pretreatment chemicals, and no materials subject to radiation damage. Changes of level produce small displacements of this float (approximately 30 mils full-scale) which are transmitted to the control 1nstrument by an inductance around a small magnet1c extension of the float. The inductance is

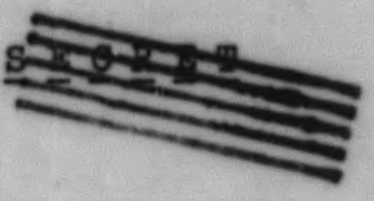

$-24-$

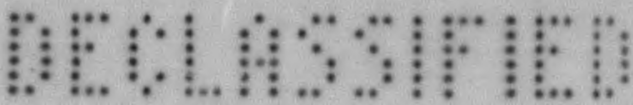


OFFICIAL USE ONLY

DWG. 13302

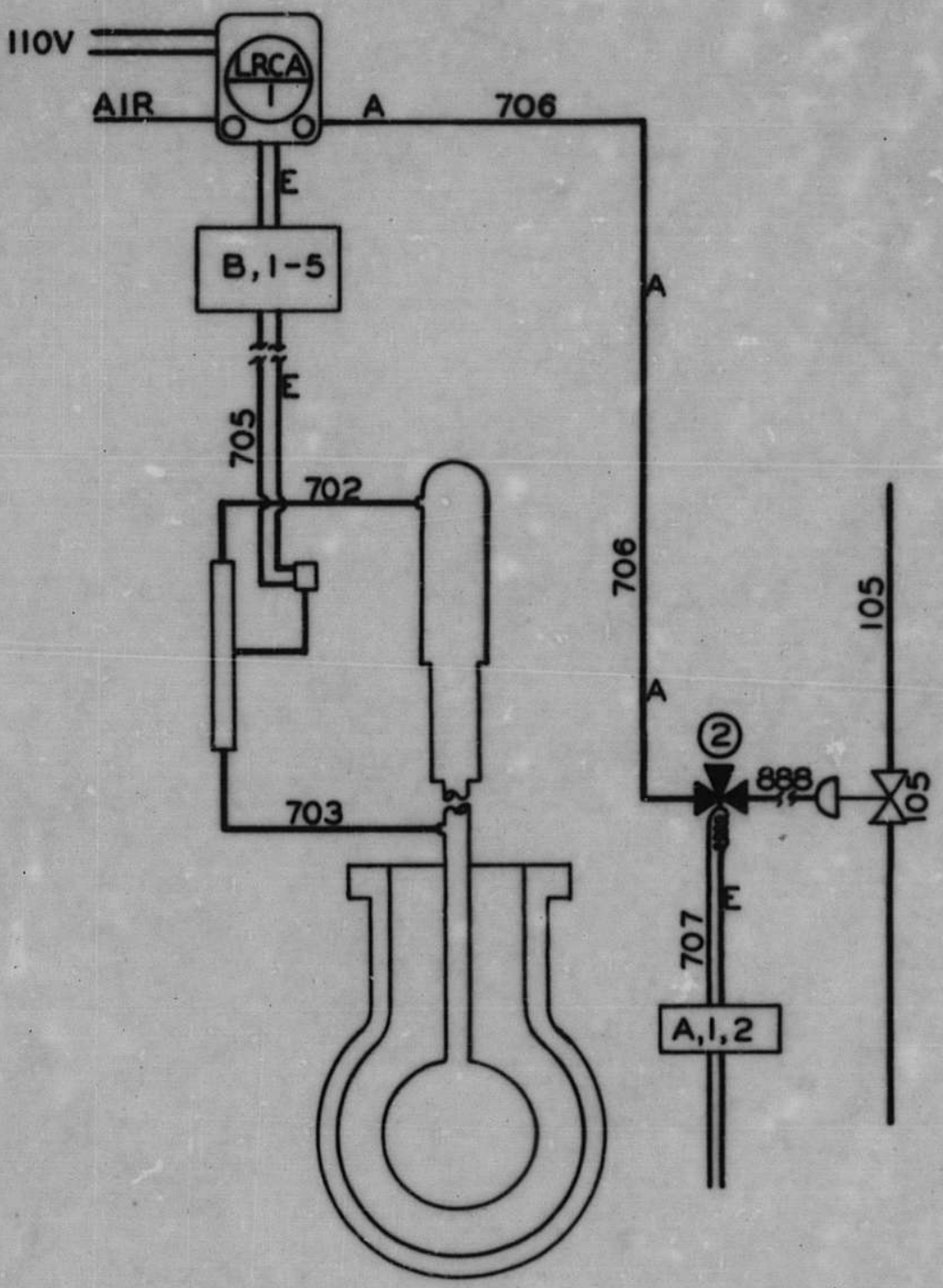

Fig. 9-Pressurizer Level $-25-$ 


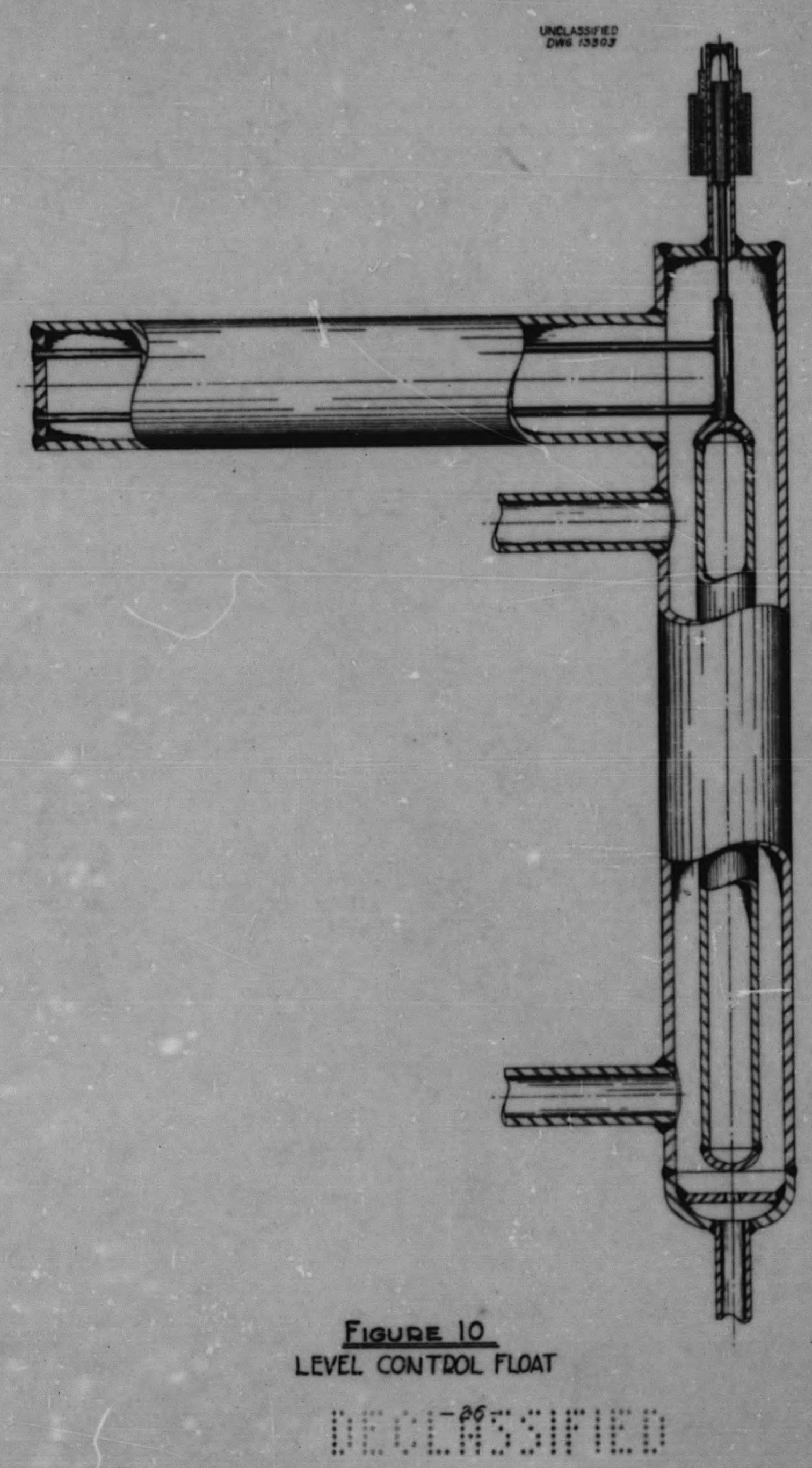




\section{$\underline{\text { TABLB } 2}$}

\section{PRESSURIZER LEVEL CONTROLLER}

\section{LRCA -1}

\section{Rece1ver - Foxboro Dynalog C1rcular Chart Controller for use} with Wianco cell

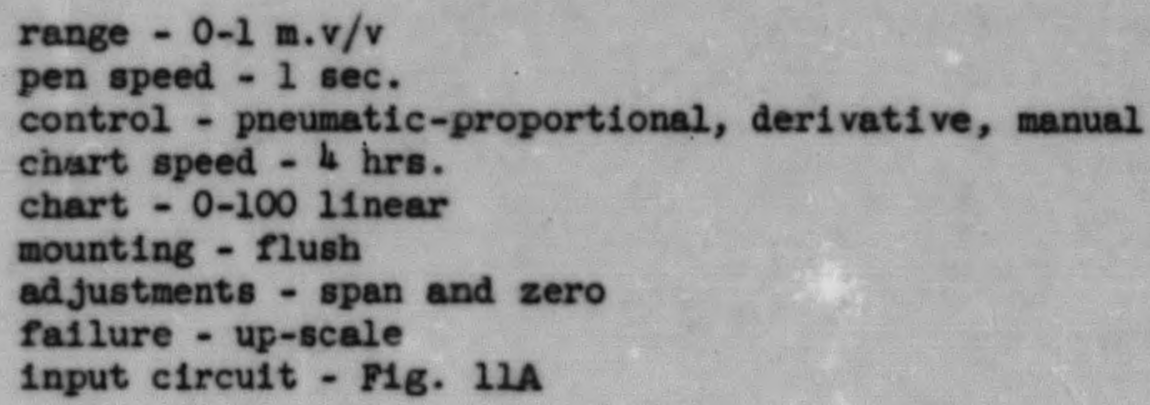

Contacts*

$1 \mathrm{CR}$ - Interlock (low level)

$1 \mathrm{CD}$ - alarm (high level) - F.0.

Locat1on - panel board

Transmitter - Schevitz Microformer - MW level cell

$$
\begin{aligned}
& \text { type }-18 \mathrm{LCT} \\
& \text { range }-0.8 \text { volt/volt-1nch }
\end{aligned}
$$

J. B. Terminals - B, 1-5

Location - Reactor compartment

\section{Aux1liary Equipment}

(105) - control element - 1/8" ss Belfield, falls open

$$
\text { Location - Soup cell }
$$

(2) - Solenoid valve - 1/4" Asco, falls open

J. B. Terminals - A4, 1-2

$$
\text { Locat1on - north face of shield }
$$

* CR - close on rise

CD - close on arop

FO - falls open

FC - fails closed
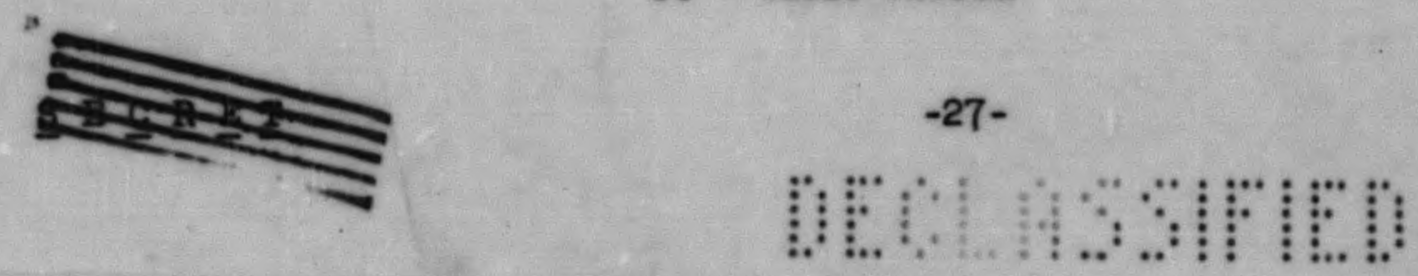



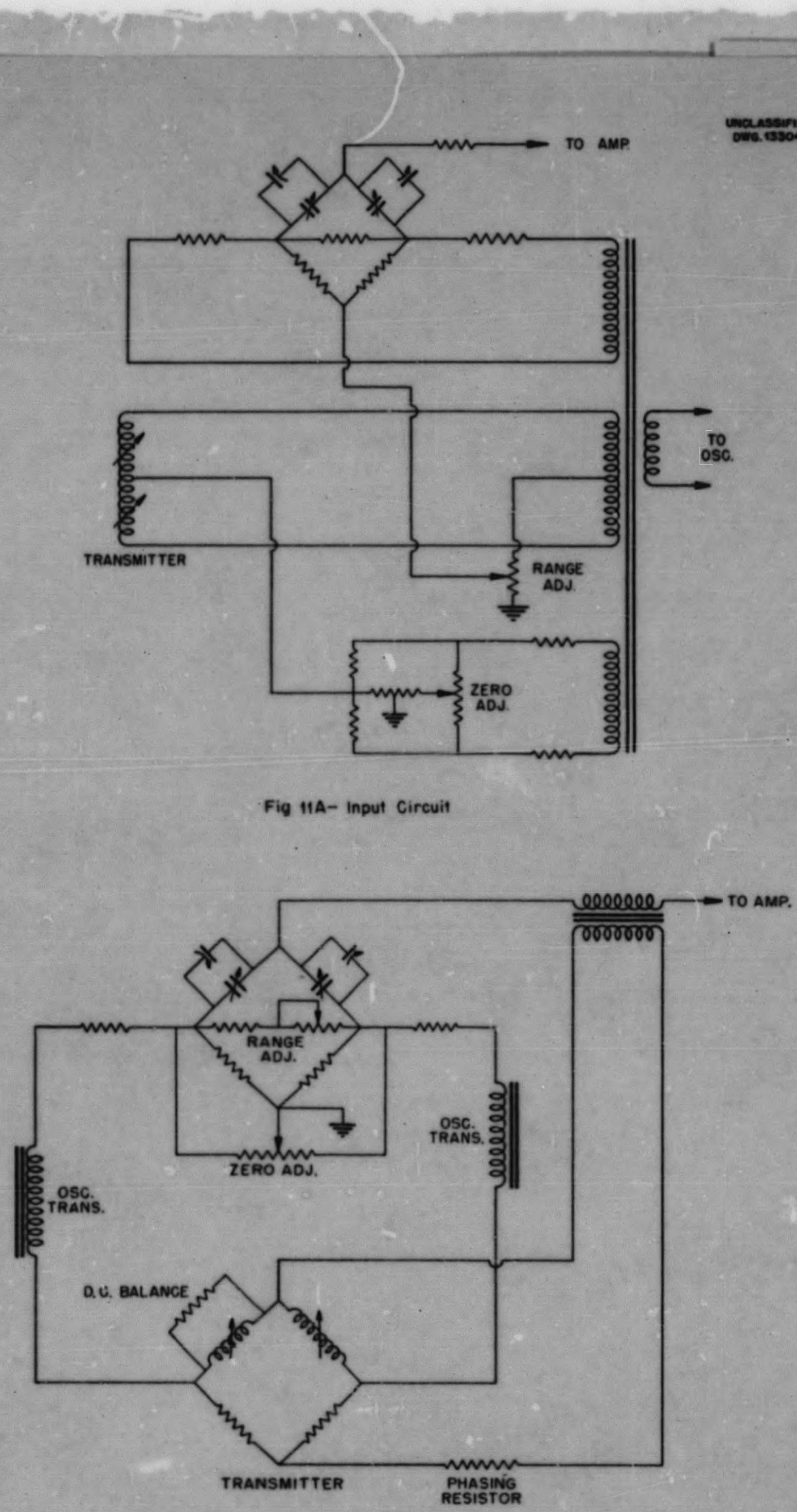

Fig. 118- Input Circuit

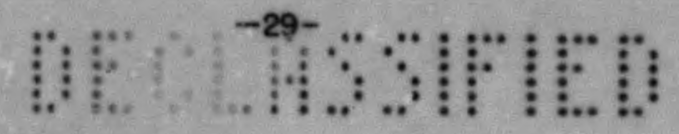




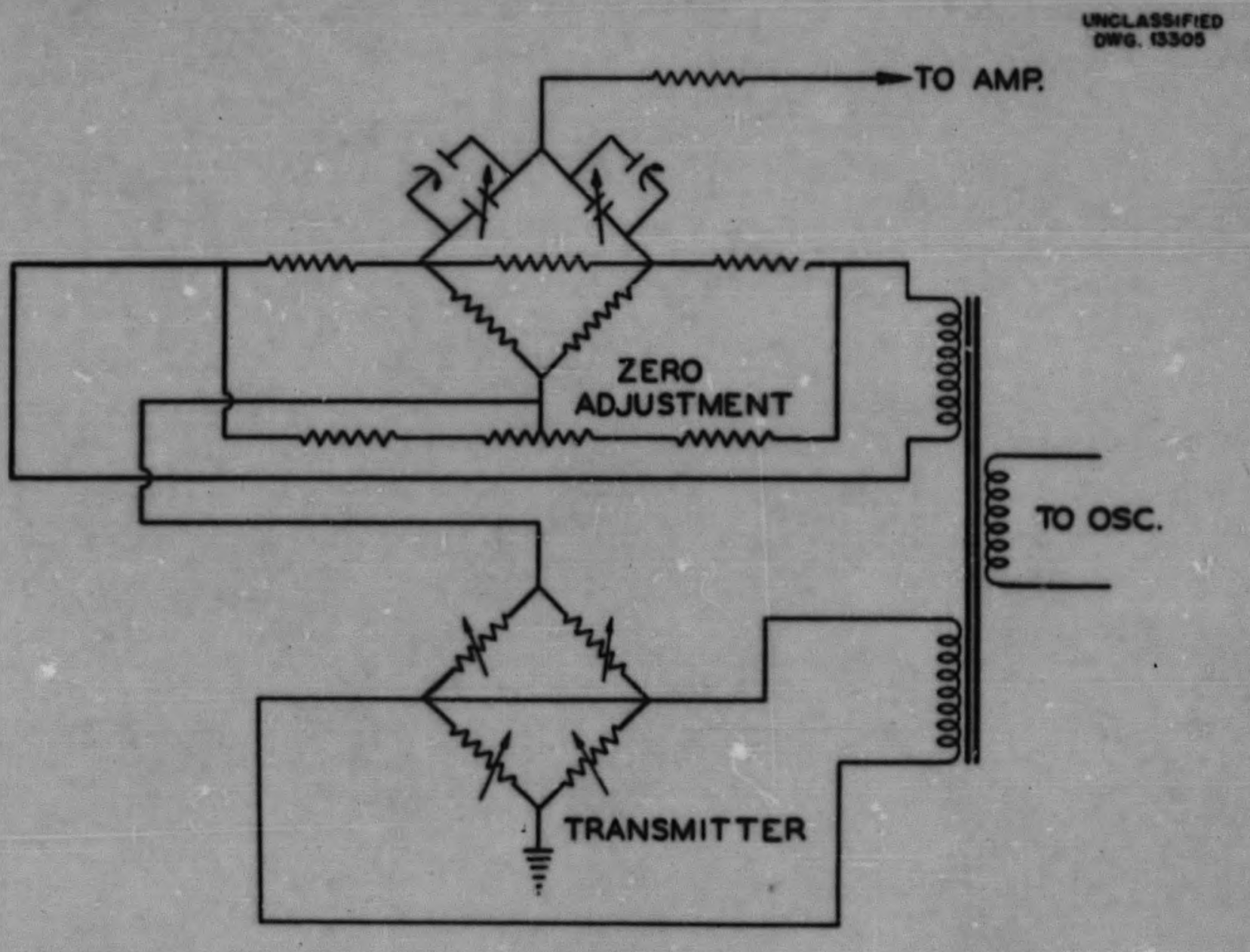

Fig. $11 \mathrm{C}$ - Input Circuit

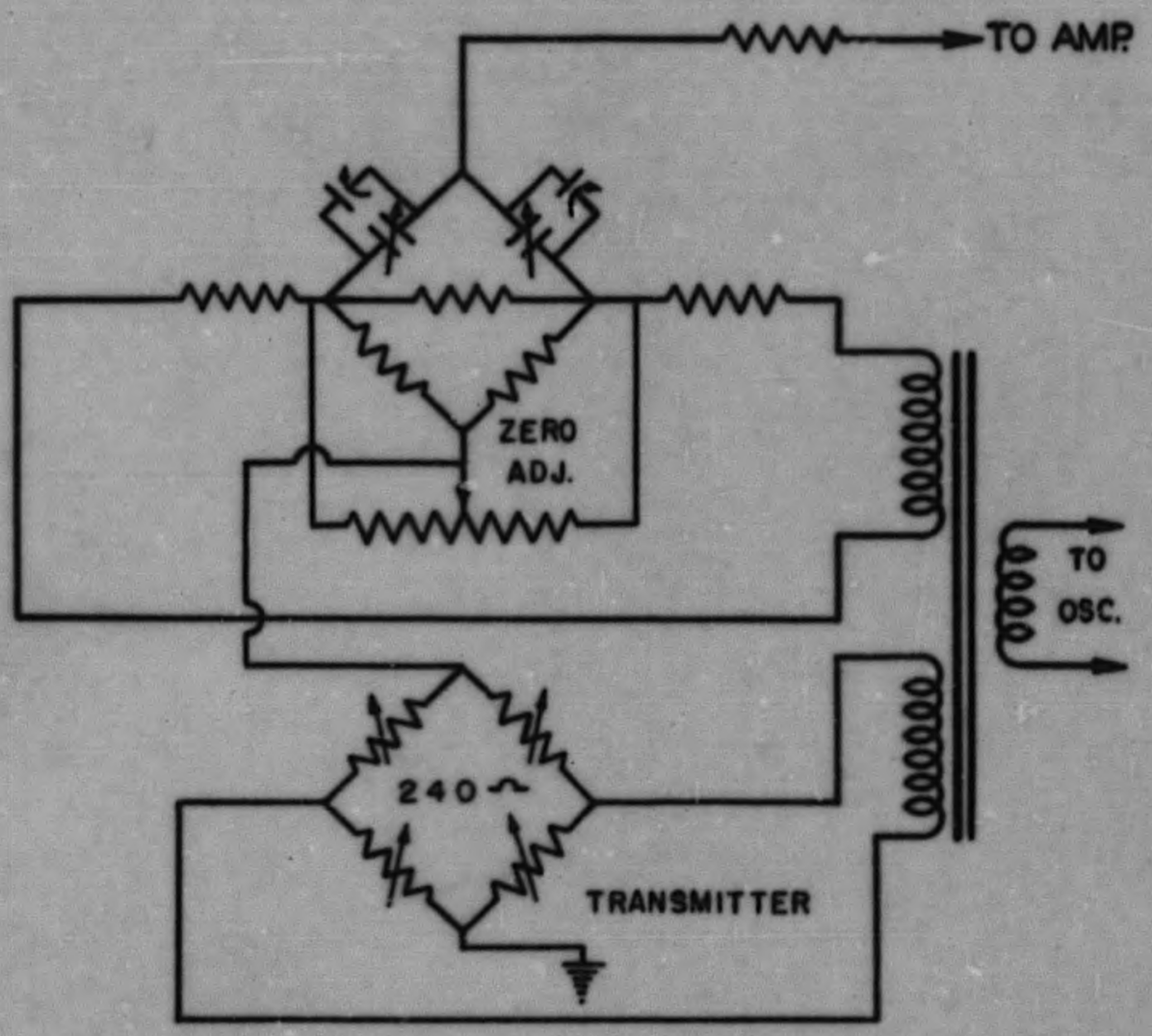

Fig. 11D-Input Circuit

(a 


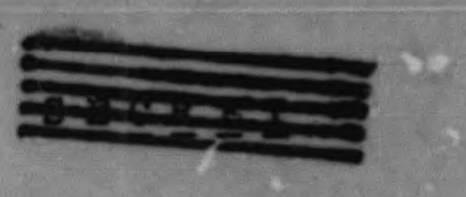

by the solenold valve designated as 2 in Figure 9. This valve is interlocked with the main dump valve so if the latter fails" to open on an emergency signal, valve 2 operates to open the let-down valve, thereby dumping the soup through 1 t.

\section{Soup Pressure and Cxygen Feed}

F1gure 12 and rable 3 show the essential features of this phase of the reactor. While pressurization and oxygen feed serve different functions their controls are so interrelated that they are treated together.

Pressurization is provided by heating the solution in the upper part of the pressurizer by means of a steam jacket. The system pressure is then determined by the vapor pressure of the solution, so by coatrolling the solution temperature the pressure may be controlled. Vapor pressurization 1s preferable to a gaz pressurization system as 1 prevents the accumulation of an explosive mixture of hydrogen and oxygen in the fressurizer. Such an accumulation would be potentially one of the most dangerous conditions in which the reactor could be placed. An explosion would drive fuel from the presaurizer Into the vortex and very closely approach a step increase in $\mathbf{k}$ corresponding in magnitude to the $k$ value of the vortex plus the compressive value of the soup in the core. In the region in which the reactor will operate the vapor pressure changes so rapidily with temperature that pressure rather than temperature control 1 used. Consequently, the heaters of the $10 \mathrm{kw}$ boller are switched on and off by the pressurizer pressure controller to maintain the correct vapor pressure. These heaters are so connected electrically that the wattage being switched can be set manuslly to minimize pressure Pluctuations.

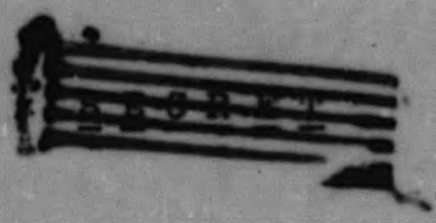




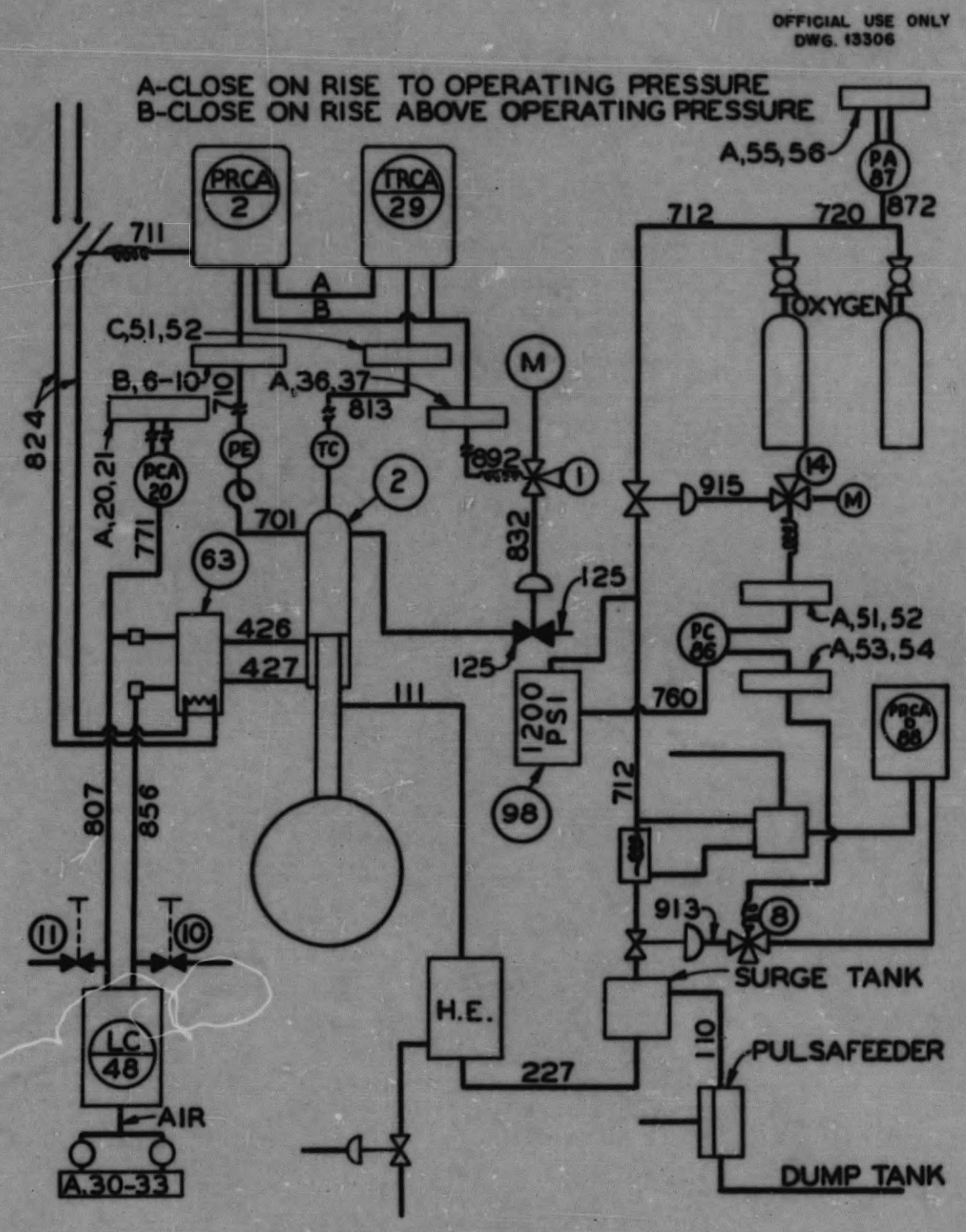

Fig. 12- Pressurizer

$$
-32 \text { - }
$$




\section{TABLE 3}

\section{SOUP PRESSURE}

\section{PRCA-2}

Rece1ver - Foxboro Dynalog C1rcular Chart Controller for use w1th Balduin cel.1

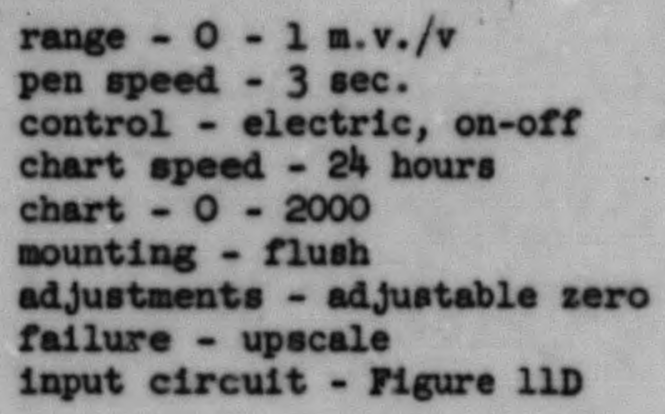

Contacts:

1 - CR - 1nterlock (low)

1 - CR - bleed valve

1 - CR - bleed valve

1 - CD - alarm (h1gh)

Location - Panel Board .

Transmitter - Beldwin strain cell 0 - 2000 psi

range - $1 \mathrm{~m} . \mathrm{v} \cdot / \mathrm{v} 2000$ psi

type - special, similar to Type C

J. B. terminals - B, $6-10$

Location - Pressure cell

Aux111ary Bquipment

(7) Sylphon in 11ne 701

(125) De-gas valve - special Spline plug - Fulton sylphon F. C. Location - soup cell

(1) Solenold valve - 1/4" Asco - F.C. J. B. terminals $A_{1}, 36-37$

Location - north face of shield

(4) Moore manual station

Location - control room

(3) Special valve - F.C.

(2) Special valve - F.C.

(8) Solenold valve - i/4" Asco - F.C. J.B. terminals $A_{1}, 53-54$

Location - north face of shield

$-33-$

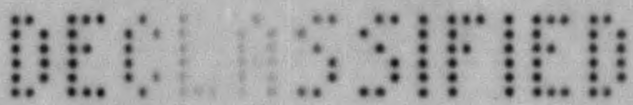




\section{TABLE 3 (CONTINUED)}

Auxillary Equipment
(9) Moore manual station
Location - control rook
(13) Moore manual station
incotion - control room
(15) Autoclave c'jeck valve in line 712

$\underline{\text { LC }-48}$

Rece1 ver - 3 - 15 psi g:ge 4-1/2", scale 0 - 100

Transmitter - Brown air output D/P cell

$$
\text { range }-0-20-600^{\prime \prime} \text { water }
$$

Location - $\mathrm{D}_{2} \mathrm{O}$ cell

\section{Auxiliary Equipment}

$$
\begin{aligned}
& \text { (5) - Seal pot Couple to } 10 \mathrm{kw} \text { boller } \\
& \text { (6) - Seal pot Al06 pipe nipple } \\
& \text { (10) }-1 / 8^{\prime \prime} \text { Hoke Mount close as possible to recelver } \\
& \text { (11) - 1/8" Hoke Provide extension handle } \\
& \text { (16) - 2H air switches - } 3 \text { - } 15 \text { psi (J.B. A } 30 \text { - 33) } \\
& 1 \text { - CR (Level) - 1nterlock (heater) } \\
& \text { 1 - CD (Leve1) - 1nterlock (heater) }
\end{aligned}
$$

\section{PCAZO}

Rece1ver - Mercold pressure sultch (0 - 2000 ps1)

Contacts:

$$
\begin{aligned}
& 1 \text { CD - Interlock (p1ckup at annunciator panel) } \\
& 1 \text { CD - alarm } \\
& \text { Locat1on - near LC-48 } \\
& \text { J.B. }-A_{1}-20,21
\end{aligned}
$$

TRCA-29

Recelver - Brown C1rcular Chart Recorder

$$
\begin{aligned}
& \text { range - } 0-300^{\circ} \mathrm{c} \\
& \text { pen geed }-24 \mathrm{sec} \text {. } \\
& \text { control - electric on-ore }
\end{aligned}
$$

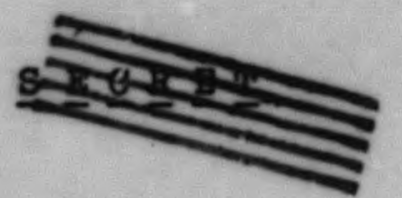

$$
-34-
$$




\section{TABLE 3 (COMTHINUED)}

\section{Rece1 ver}

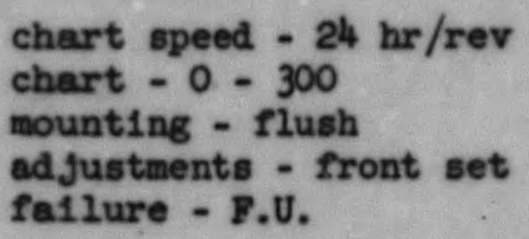

Contacts:

1 CR alarm F.0.

1 CD alarm

1 CD control

\section{Location - panel board}

Transmitter - I.C. thermocouple

T. C. vell designed in pressurizer

$$
\text { J.B. }-c_{1}-51,52
$$

$\underline{\text { PA-87 }}$

Recelver - 0 - 1500 psi Mercold pressure switch

Location - north face of shield

Contact:

1 CR alarm

J.B. $A_{1}-55,56$

PC-86

Rece1ver - 0 - 1500 psi Mercold pressure switch

Location - pressure cell compartment

Contact - SPDT

J.B. $A_{2}-48-50$

Aux111ary Equipment

(14) Solenold valve - 1/4" Asco F.C.

J. B. Terminals $A_{1}=51,52$

Location - north face of shield 
The pressurizer can become gas-bound so the vapor pressure does not control the total pressure. Mock-up tests have demonstrated that the vapor controlled region is a rather thin layer (a few inches) just above the solution surface when appreciable gas is present. The bleed valve in 1 ine 125 and its controls are provided to care for the gas, elther oxygen from the oxygenating system or decomposition gases from the solution. A thermocouple in the top of the pressurizer senses the temperature, anc through TRC-29 uses this temperature to bleed off the gas through valve 125. The stratiflcation of the gas and vapor w11l cause the thermocouple temperature to be below that correspondIng to desired vapor pressure. This causes valve 125 to ogen and relleve the gas binding. When the system is being brought up to operating pressure this valve should be closed so the temperature-controlled contacts of TRC-29 are connected in series with pressure-controlled contacts of PRCA-2 so valve 125 opens automatically only when the pressure 16 correct and the temperature is low. Obviously, the temperature control point of TRC-29 must be set to correspond with the pressure control point of PRCA-2. Valve 125 also serves as a safety rellef valve, opening when PRCA-2 Indicates an abnormal pressure.

The $10 \mathrm{kw}$ boller, 1 tem 63 , is protected by instruments LIA48 and PC20, the f1rst for water level and the second for pressure protection. Both of these are located Inside the shield for safety, elnce a leak from the pressurizer into the steam jacket would make them quite hot. LIA 48 is a Foxboro differential pressure cell wh air output operating the three switches. Since it is inside the shield three electifcal signals are brought outside. The Internediate point is the $\mathrm{flll}$ point, while high and low contacts are connected In the heater control circuit so the heaters cannot operate if the water is low

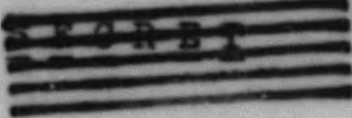




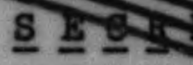

or if the boller has been over-f1lled. PC20 1s a 1500 psi pressure switch also connected in the heater circult to prevent over pressure operation. Thus, subject to permission from water level and pressure instruments the boller heaters may be switched as demanded by the pressurizer temperature.

Oxygen in the solution is necessary for chemical. stability, so a means must be provided for introducing oxygen when the reactor is operated at such a low power level that 1 t does not generate 1 ts own. Th1s is cared for by the oxygen feed arrangement shown in F1gure 12. Oxygen is metered into the system by valve 3 from the 1ntermediate gas storage. This flow is measured with a diffarential pressure cell across an oriflce, the cell in turn being connected to a recorder and controller. The oxygen flows into the surge tank, and an equilibrium liquid level will be reached when the absorption of the liquid surface and falling spray balances the feed rate. To meet the estimated stability requirement of approximately $25 \mathrm{ppm}$, the oxygen feed rate will be adjustable over a range of 1 to $15 \mathrm{cc} /$ minute at operating pressure.

The double valving connection in the oxygen system is provided for activity safety. The intermediate cylinder is kept charged by the pressure switch and valve 3 . This switch closes valve 2 before opening valve 3 , so during the brier charging interval the oxygen supply to the reactor is shut off. Two oxygen supplies are manlfolded to the system with a low pressure alarm as protection against failure of the oxygen supply.

\section{Soup Circulation and Heat Bxchanger}

The 1nstrumentation on the main soup circulating system, 1ncluding the pump and heat exchanger is shown in Figure 13, with specifications in Table 4.

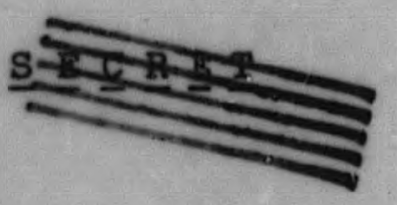




\section{TABLE 4}

$\underline{\text { TIA-4 }}$

Rece1ver - Brown Circular Scale Contact Controller

$$
\begin{aligned}
& \text { range - 0-300 } \mathrm{c} \\
& \text { pen speed }-4-1 / 2 \mathrm{sec} . \\
& \text { chart speed }-24 \mathrm{hr} \text {. } \\
& \text { chart - 0-300 linear } \\
& \text { mounting - flush } \\
& \text { adjustments - front set } \\
& \text { fallure - fails upscale }
\end{aligned}
$$

Contacts: $1 \mathrm{CR}$ interlock (differential adjustment)

1 CD (F.o.) (differential adjustment)

Location - panel board

Transmitter - I.C. thermocouple in 11ne 101

$$
\text { J.B. } c_{1}-49,50
$$

WR-5

Recelver - Brown Strip Chart Recorder

$$
\begin{aligned}
& \text { range }-0-3 \mathrm{mv}: \\
& \text { pen speed }-24 \mathrm{sec} . \\
& \text { chart speed }-10 \text { inches } / \mathrm{hr} . \\
& \text { chart }-0-100 \text { 11near } \\
& \text { mounting - flush } \\
& \text { Location - panel board }
\end{aligned}
$$

Transm1tter - I.C. T.C. I1nes 101, 102

$$
\text { J.B. } c_{1}-53-56
$$

Auxillary Equipment - 1 contact T.C. adaptor (as built, insulated)

$\underline{\text { IRC-8 }}$

Recelver - Brown C.C. Recorder and Controller

Inductance bridge type

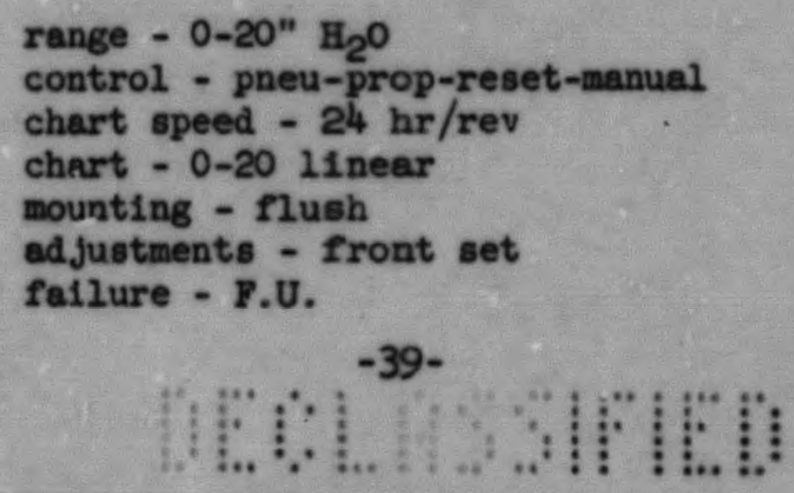




\section{TABLE 4 ( COMTINUED)}

$\underline{\text { LRC-8 }}$ (Continued)

Contacts: None
Location - panel board

Junction box: $A_{1}=17-19$

Transmitter - Brown Hg manometer Inductance transmitter

range $-0-20 " \mathrm{H}_{2} \mathrm{O}$
Location - compartment in west face of shield

Auxiliary Bquipment

(7) \& (8) seal pots

(3) \& (4) $1 / 8$ " Hoke valves with extension handles

(2) $1 / 4$ " Asco soleno1d valve (north face of shleld)

(309) control element MH $1^{\prime \prime}$ valve (F.C.) (location in trench)

\section{TIA-16}

Recelver - Symplytrol Pyrometer with automatic reset

$$
\begin{aligned}
& \text { range }-0-500^{\circ} \mathrm{F} \\
& \text { mount }- \text { Plush }
\end{aligned}
$$

Contacts: $1 \mathrm{CD}$ alarm

Location - control room

Transmitter - I.C. couple with surface temp. adaptors J.B. $c_{1}-43-44$

ICA-22

Recelver - G.E. Under current reley

$$
\begin{aligned}
& \text { range - 0-5 amps } \\
& \text { mount - flush in draw-out case } \\
& \text { type - IAC-55 }
\end{aligned}
$$

Contacts: 1 normally closed - Interlock

1 normally closed - alarm

Location - panel board

Auxiliary Equipment - current transformer 100/5 amps

(relay purchased as over current, changed to under current) $-40-$

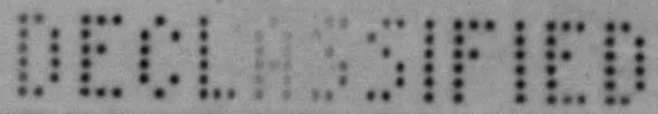




\section{TABLE 4 (COMTINUED)}

ICA -18

Recel ver - G.E. Over current relay

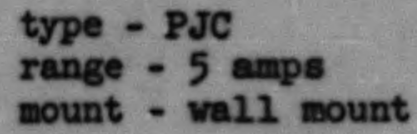

Contacts: 1 N.C. Interlock

1 n.c. alarm

Location - panel board

II -36

G.E. Anmeter

$$
\begin{aligned}
& \text { range }-0-5 \text { amps } \\
& \text { scale }-0-100 \text { amps }
\end{aligned}
$$

PA-19

Recelver - MH pressure switch

$$
\text { range }-0-300 \text { psi }
$$

Contacts: 1 CD alarm

Locat1on - soup o11 pump compartment

J.B. $A_{1}=40,41$

PCA -72

Recelver - MH pressure switch

$$
\text { range }-0-300 \mathrm{psi}
$$

Contacts: 1 CR 1nterlock

1 CK alarm

Locat1on - soup o11 pump compartment

J.B. $A_{1}-42,43$

PC-21

Recelver - vH pressure swltch

$$
\begin{aligned}
& \text { range }-0-150 \text { psi } \\
& -41-
\end{aligned}
$$

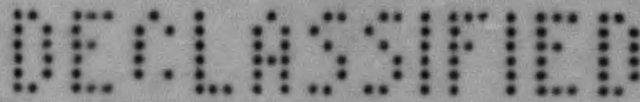




\section{TABLE 4 (COMFINUSD)}

PC-21 (Continued)

Contacts: $1 \mathrm{CR}$ interlock

Location - south face of shield

Auxiliery Equipment - 150 psi brass needle valve, 11 ne 802

PI-38

Receiver - 6" Clapp 0-300 psi

Location - west fece of shield

Aux111ary Bquipment - (5) $1 / 8^{\prime \prime}$ Hoke valve

(6) $1 / 8^{\prime \prime}$ Check valve

$\underline{\text { LI-73 }}$ - S1ght Glass

Location - vest face of shield

$\mathrm{s}$

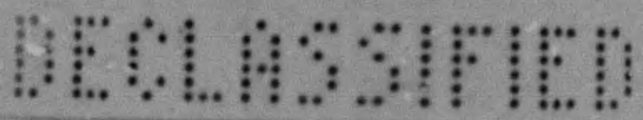




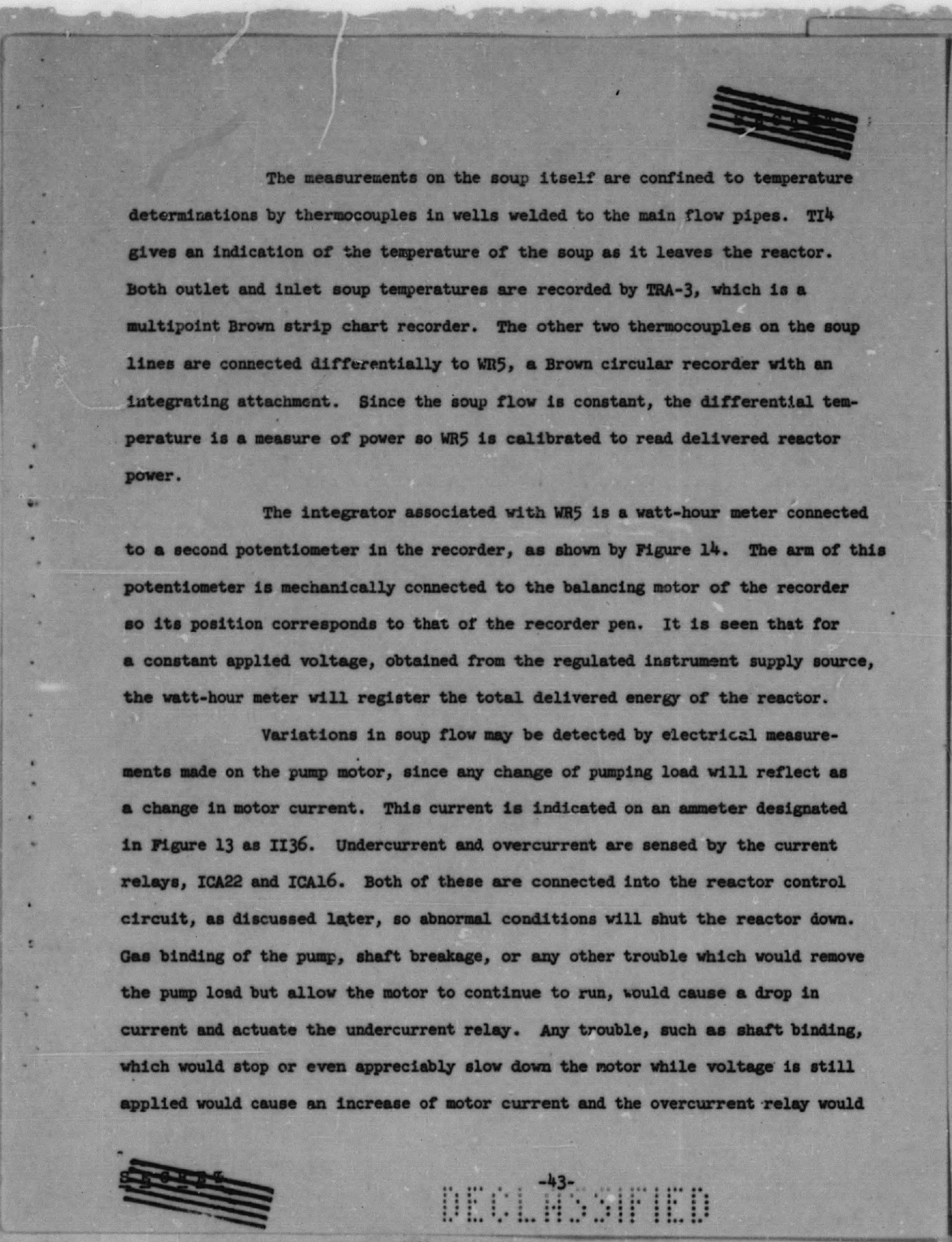




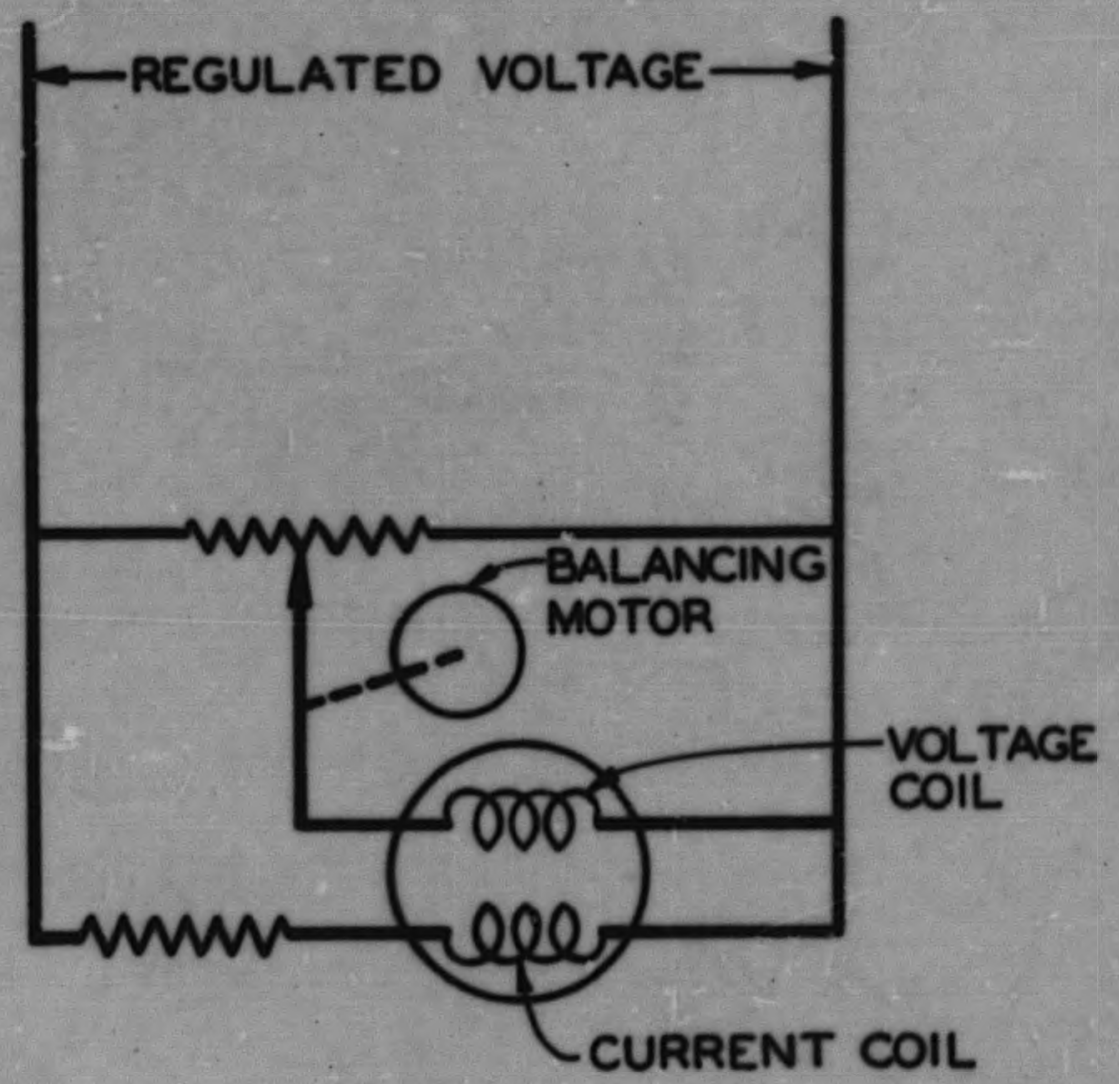

Fig. 14-Power Integrator

$-44-$

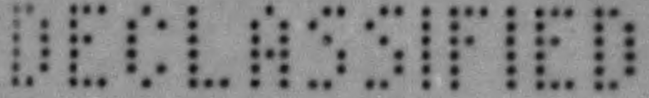




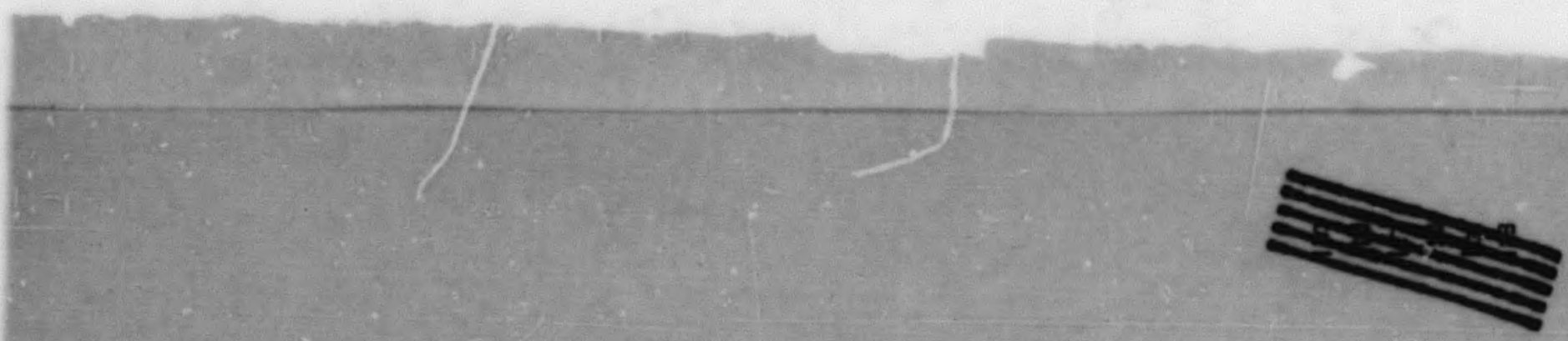

function. Both of these relays are quick operat1ng. Thus, no stoppage of soup flow can occur without the reactor shutting down and consequently no serious overheating can occur from th1s cause.

The pump motor is o1l-cooled and w11l quickly overheat $1 f$ there 1s any 1nterruption of 011 flow. Over and under pressure switches PA19 and 72 on the delivery line of the ofl pump provide alarm signals if trouble occurs In the o1l system. 011 pump fallure or low o1l level will cause the low pressure elarm to function while plugging of the ofl line or sludging in the ofl will cause the h1gh pressure alarm to operate. The cooling water supply is interlocked through pressure swltch PC21 to the soup c1rculating pump motor so the pump cannot be started $1 f$ cooling water is not flowing. O1l level in the reservolr may be checked by slight glass LI73 by opening the valves connecting the glass and reservo1r. These valves are normally closed so radioactive material cannot get outelde of the shleld even 19 a leak from the soup system 1nto the conling o1l does occur. Pressure gage PI38 gives an Indication of any gassing due to radiation decomposition of the oll.

The circulating pump motor is further protected by a simplytrol over-temperature alarm, TIA16, operating from a thermocouple on the motor casing. The water level in the main heat exchanger is indicated and cuutrolled by LIC8. Th1s Instrument cons1sts of a Brown differentiel pressure cell and a pneumatic controller. The control point of the 1nstrument may be adjusted at the instrument so level or rate of fill may be controlled manually. The controller operates the feed water valve in 11 ne 309 to regulate the supply from the feed water pump. However, this control may be overridden and the valve closed $1 f$ excess activity is detected in the steam. Th1s is accomplished through the solenold valve in the alr line. The operation of the monitor circuits will

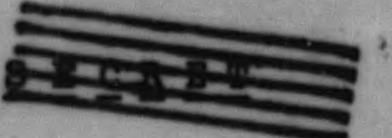


be aiscussed in a later section.

\section{Concentration}

The determination of concentration in the soup system is greatly complicated by the nature of the solution and system - a high pressure system containing a very radioastive solution which is gassing rather freely. A measurement scheme which may solve one difficulty generally falls to meet some other necessary specification.

The method used for the BRE is somenhat indirect and is subject to certaln errors. The general operation of the concentration control has been discussed in connection with reactivity control, and schematic diagram of the actual measuring system is given in Figure 15. The condensate tanks are suspended from a Baldwin weigh cell which is in turn connected electrically to a Foxboro 1ndicator. The specifications for this instrument are given in Table 5 .

The soup dump tank level measurement serves as a liquid balance check on the concentration calculations. A leak, whether due to structural fallure or to a valve leakage to the outer dump tanks, w11l result in an error In concentration values. A leak out of the system should be detected promptly by one of the activity monitors, but one into the outer tanks would not show up except as a loss of level in the system. When the soup is dumped to the regular dump tanks the level Indicator, LII 4 , serves so a check on the total soup in the system. When the reactor is operating, this instrument is not a very rellable monitor eince the amount of soup in the core vill fluctuate with pover (and hence passing).

The level Instrument consists of a Wianco variable Inductance transmitter connected to a Foxboro Instrument. A omall olde chamber connucted
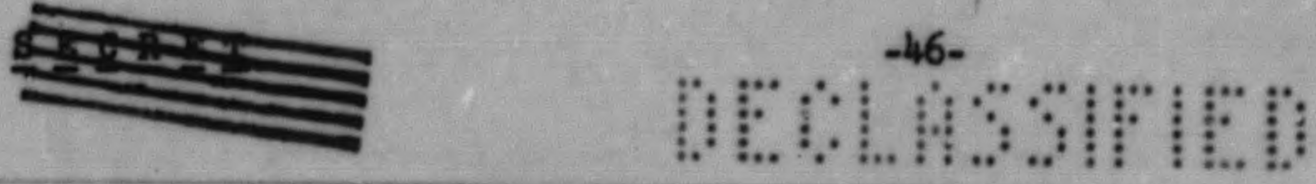

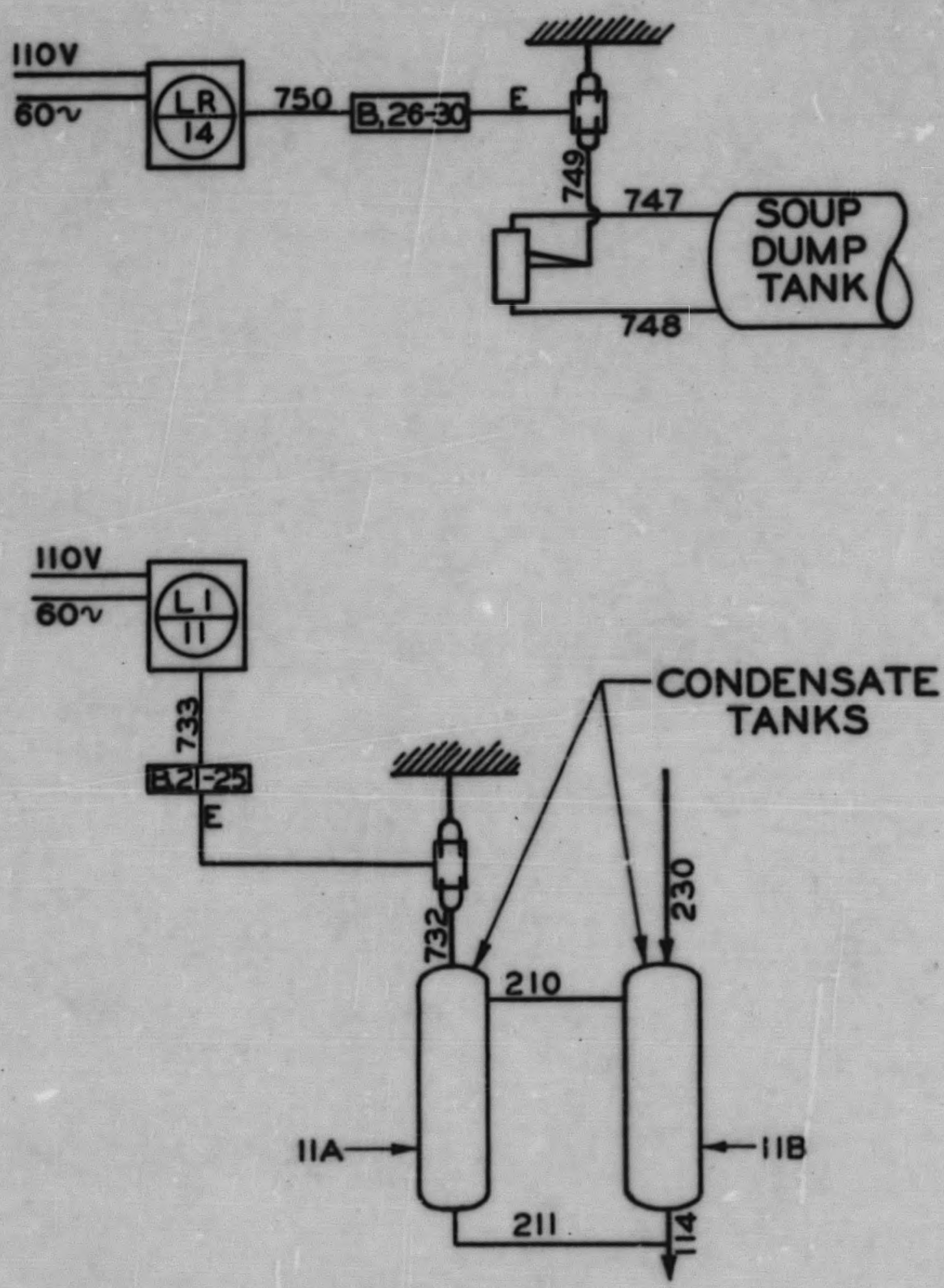

Fig. 15- Weight Systems

$$
-47-
$$

आ. 


\section{TABLE 5}

$\underline{\text { LR-14 }}$

Receiver - Foxboro Dynalog C.C. Recorder for use with Wianco cells

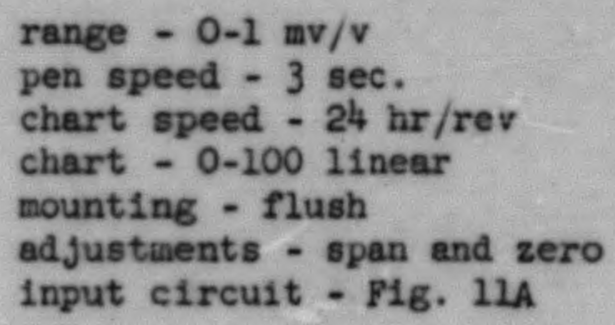

LI - 11

Rece1ver - Foxboro C.C. Indicator for use with Baldwin Load Cell

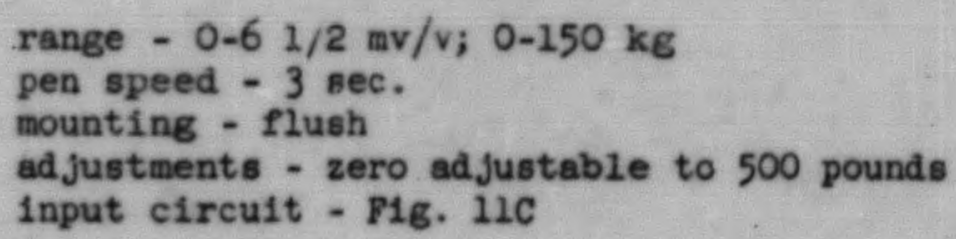

Location - panel board

Transmitter - Baldwin tension load cell 2 " lead shield

range - 0-180 kg

J. B. $B_{1}=21-25$

Location - soup cell

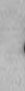

$-48$. 
to the dump tanks by tubes serves as a weigh tank suspended from the wianco unit. Thus, level is determined by weighing the liquid in this side tank.

\section{Soup off-Gas Recombiner}

The soup off-gas recombiner system is given in Figure 16. Reference to Figure 4 will show that this is a detall of the system between the soup off-gas condenser and the coid traps. The Instrument specifications are presented in Table 6.

The flow of gas and steam to the flame recombiner is metered by a Foxboro differential pressure cell and Dynalog controller across the orifice. This flow 1.8 used to control the cooling weter to the off-gas condenser to prevent flash-backs from the recombiner to the condenser. At high gas flows the veloc1ty in line 116 is high enough to prevent a Plash-back, but at low gas flows it is necessary to 1ncrease the steam content. This is accomplished by decreasing the cooling water to the condensers. The absolute pressure in this line is recorded by PR -78 , consisting of a Baldwln pressure cell and a Foxboro c1rcular chart recorder.

The only other instrument control on the recombiner system is temperature control of the cooling water to the flame recombiner. The temperature of the gas between the flame and catalytic recombiners is sensed by a thermocouple which is connected to a Brown controller (TRC-6) which effectively maintains the correct steam and gas flow to the catalytic unit.

Numerous temperatures may be determined with thermocouples indicated a TI17, which are connected to a 48-point Brown precision Indicator. In addition, the flame recombiner temperature is recorded on TRA-3. These various temperatures in conjunction with the cooling water flow meters, FI84 and FI 58, will furnish data for calculation of the gas recombination rate.

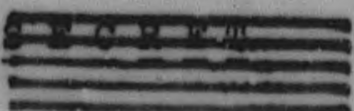




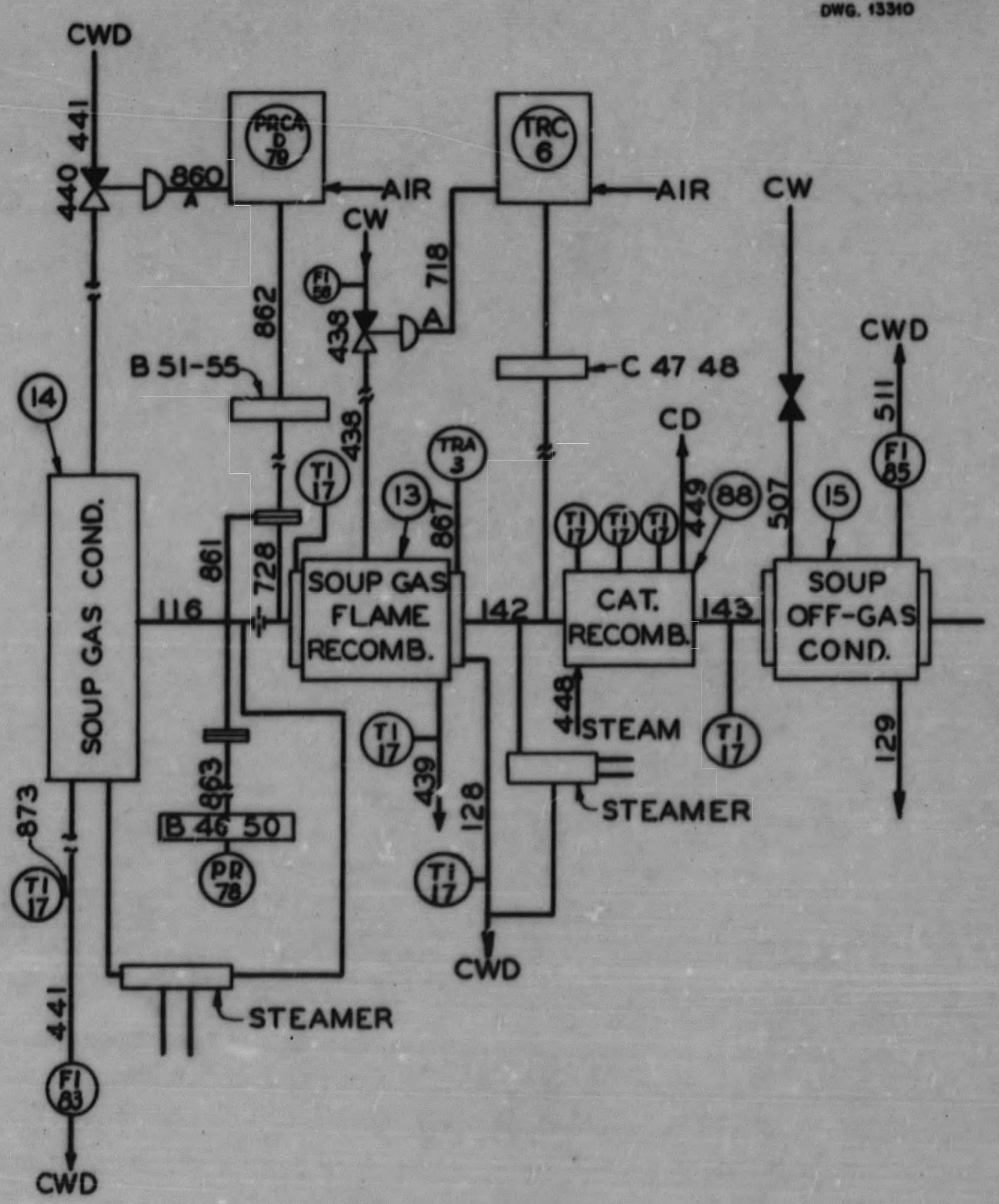

Fig. 16-Soup Off-gcs

$-50-$ 


\section{TABLE 6}

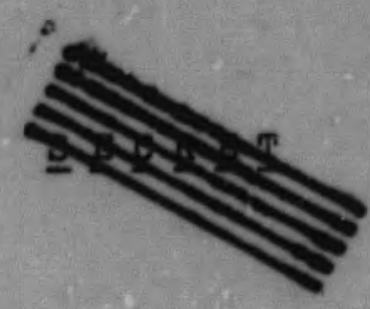

$\underline{P R-78}$

Rece1ver - Foxboro Dynalog C.C. Recorder for use with Baldwin pressure cell

$$
\begin{aligned}
& \text { range }-0-1 / 4 \mathrm{mv} / \mathrm{v} \\
& \text { pen speed }-1 \mathrm{sec} \\
& \text { chart speed }-24 \mathrm{hr} / \mathrm{rev} \\
& \text { chart }-0-50 \mathrm{psi} \\
& \text { mount }- \text { Plush } \\
& \text { edjustment }- \text { zero } \\
& \text { Input circu1t - F1g. 11D }
\end{aligned}
$$

Locat1on - panel board

Transm1tters - Balâw1 pressure cell

$$
\text { range - 0-200 psi, 0-1 mw }
$$

Location - pressure cell compartment

$$
\text { J.B. } B_{1}-46-50
$$

\section{PRCA/D-79}

Rece1ver - Foxboro Dynalog C.C. Recorder Controller

$$
\begin{aligned}
& \text { range - 0-20" } \\
& \text { pen speed - } 3 \text { sec. } \\
& \text { chart speed }-24 \mathrm{hr} / \mathrm{rev}
\end{aligned}
$$$$
\text { control - pneu, prop, reset, manual }
$$$$
\text { mounting - flush }
$$$$
\text { chart - 0-20" }
$$$$
\text { adjustments - front set and zero }
$$$$
\text { failure - fail downscale }
$$$$
\text { input circuit - Fig. 11D }
$$

Locat1on - panel board

$$
\text { Contacts: } 1 \mathrm{CD} \text { alarii }
$$

Transmitter - Foxboro D/P cell

$$
\begin{aligned}
& \text { range - 0-20" } \\
& \text { Location - } 1 \text { ine } 116 \text { (soup cel1) } \\
& \text { J.B. } B_{1}-51-55
\end{aligned}
$$

Aluxillary Equipment - (440) Control element MB valve (F.0.)

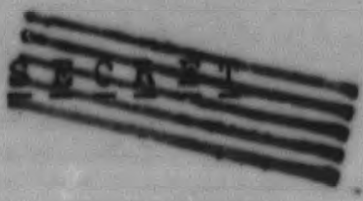

$-51-$ 


\section{TABLE 6 (CONTINUED)}

\section{FI-83}

$12 \mathrm{gpm}$ water meter

$$
\text { Location - 11ne } 441
$$

FI-85

$12 \mathrm{gpm}$ water meter

$$
\text { Location - 11ne } 511
$$

TRA-3

(See Table 12)

\section{$\underline{\text { TRC-6 }}$}

Recelver - Brown C.C. A1r-0-11ne Controller

$$
\begin{aligned}
& \text { range - } 0-400^{\circ} \mathrm{C} \\
& \text { pen speed }-12 \text { sec. } \\
& \text { control - pneu, prop, reset, manual } \\
& \text { chart speed }-24 \mathrm{hr} / \mathrm{rev} \\
& \text { chart }-0-40011 \text { near } \\
& \text { mount - flush } \\
& \text { adjustments - front set } \\
& \text { failure - upscale }
\end{aligned}
$$

$$
\text { Contacts: } 1 \text { CR alarm }
$$

$$
\text { Locat1on - panel board }
$$

Transmitter - I.C. couple with T.C. weld line 142

$$
\text { J.B. } c_{1}=47,48
$$

Auxiliary Equipment - (438) MV valve control element (F.0.)

\section{FI-58}

12 Epm vater meter

$$
\text { Location - 11ne } 438
$$

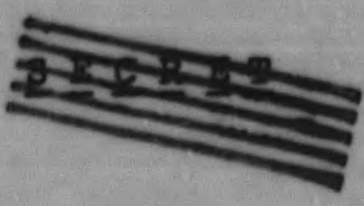

$$
-52-
$$


The pressure in this system is controlled by the mercury level in the seal pot shown in Figure 4 between the charcoal traps and the stack fan. For normal operation the vacuum prap is not in operation.

\section{Reflector Pressure and Level}

The reflector is pressurized with helium to a value slightly (approximately $50 \mathrm{psi}$ ) above the core pressure by the differential pressure controller, PRCA/D 10, Pigure 17. Two Beldwin pressure cells, 4 and 5, are connected electrically to PRCA/D 10, a Foxboro Dynalog pressure controller. The pneumatic control signal from th1s instrument 1s applied to valves $267 \mathrm{~A}$ and 270. Helium 1s supplied from cylinders manifolded to 11 ine 267 at the right of F1gure 17. A pressure differential, other than the set-point of the instrument, between core and reflector w11l apply alr to valve $267 \mathrm{~A}$ or 270 , depending upon the direction of the differential. Low reflector pressure yill cause valve $267 \mathrm{~A}$ to open and admit hellum to the reflector space through the control rod hous1ngs (see F1gure 4). Excess reflector pressure opens valve 270 and bleeds helium from the reflector to the dump tanks.

The requirements for proper pressure control during a dump of reflector or core are not met by the basic control just outlined. The two hellum control valves are necessarily amall to give suitably fine control, and hence cannot pass hellum rap1dly enough to keep pressures equalized during a dump. Actually, these valves have a $\mathrm{Cr}$ of .07 and the equation for valve flow,

$$
Q=\frac{61 \mathrm{Cv} \sqrt{\left(P_{1}-P_{2}\right) P_{2}}}{\sqrt{6}} \text {, }
$$

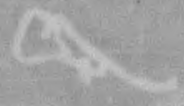

may be applied to get maximum flow. In this equation, Q is flow in $s c \mathrm{f}^{\mathrm{h}}, \mathrm{P}_{1}$ and $P_{2}$ are pressures on either side in psi, and $G$ is the specific gravity of the gas referred to air.
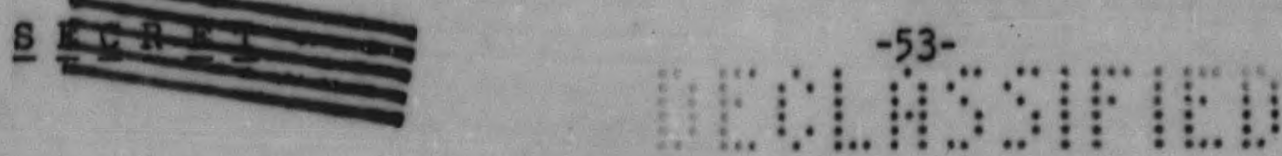
OFFICIAL USE ONLY

DWG.13311

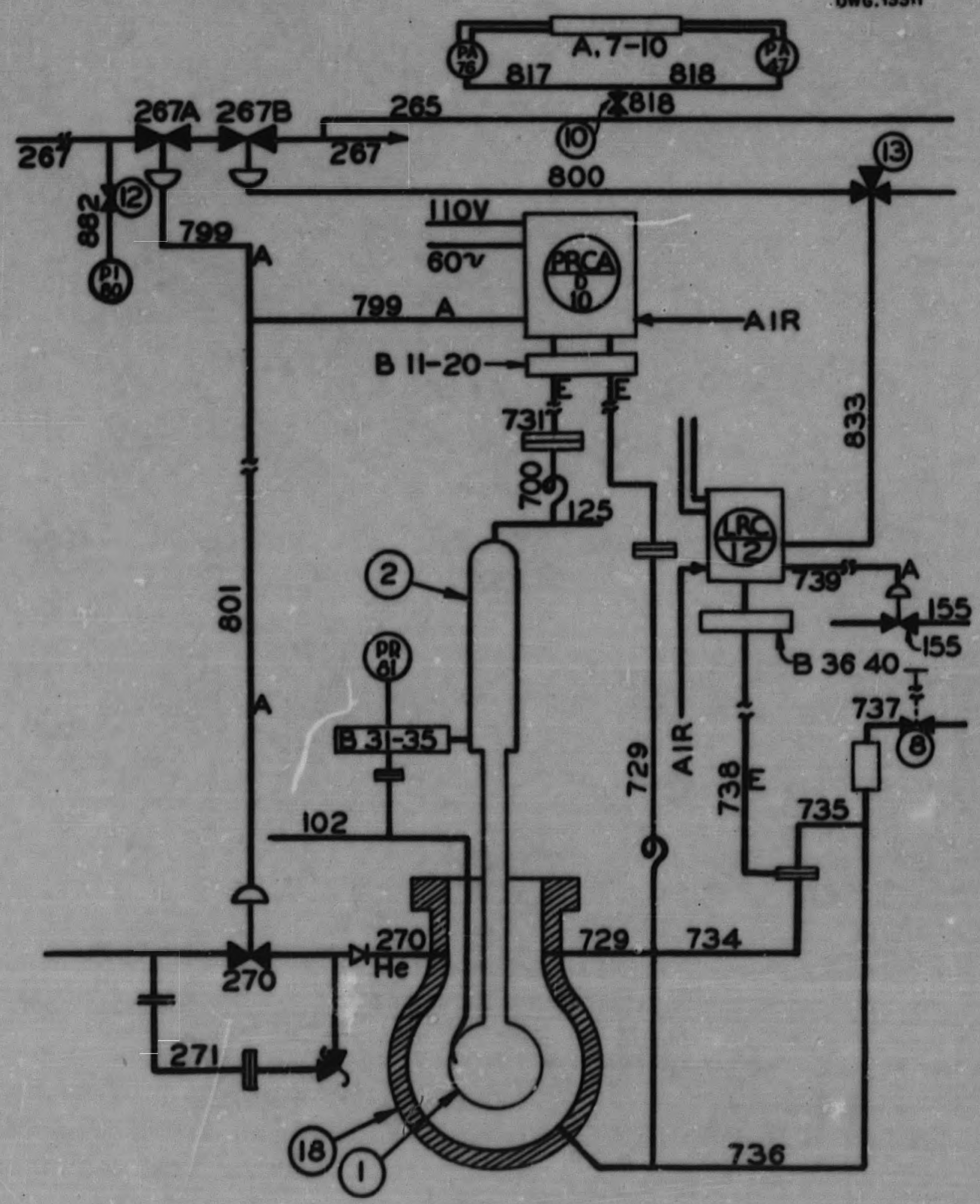

Fig. I7-Deflector

$-54-$

:

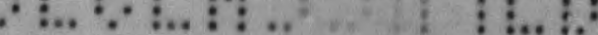




\section{TABLE 7}

$\underline{P R-81}$

Receiver - To be supplied (scope)

Transm1tter - W1anco pressure cell

$$
\text { range }-0-2000 \text { pisi }
$$

J.B. B-31 - 35

Locat1on - reactor compartment

$\underline{\text { PI }-80}$

Rece1ver - 0-1500 psi, 6" Clapp

Location - control room

Auxillary Equipment - (12) 1/8" Hoke valve, 11ne 882

$\underline{P A-47}$

Receiver - Mercoid pressure switch 0-1500 psi (CD)

Location - north face of shield

Contact: $1 \mathrm{CD}$ h1gh alarm

J.B. $A_{1}-7,8$

$\underline{P A-76}$

Recelver - Mercota 0-1500 ps1 press. switch

Locstion - north face of shiela

Contacts: 1 CR low alarm

J.B. $A_{1}-9,10$

Auxiliary Equipment - (10) 1/8" Hoke valve, 11ne 818 PRCA/D-10

Becelver - Foxboro Dynalog C.C. Recorder Controller

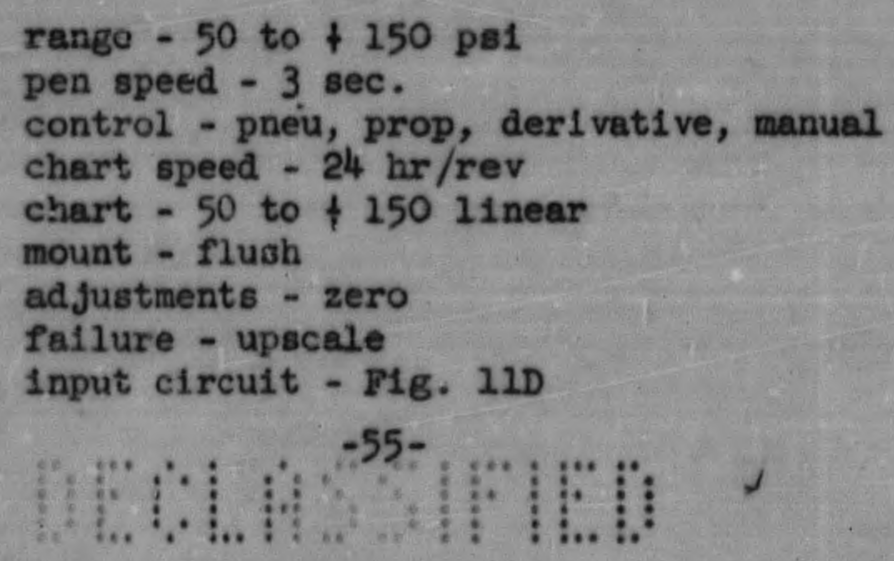


$\underline{\text { PRCA } / \mathrm{D}-10}$ (Continued)

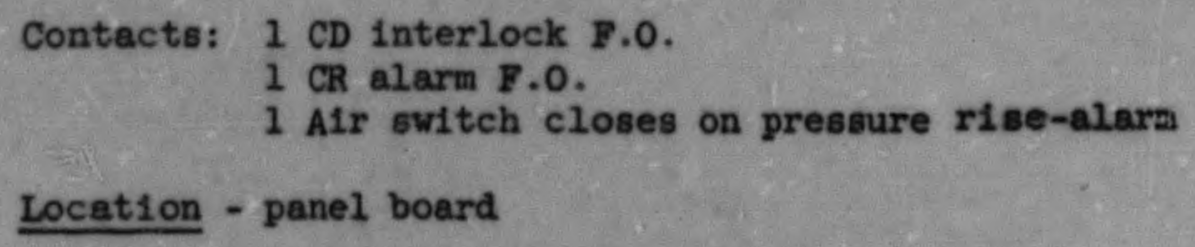

Transmitters - (4) \& (5) Baldw1n pressure cells

range $-0-2000$ psi

J.B. $B_{1}=11=20$

Location - pressure cell comp.

Auxil1ary Equipment - Sylphons in 11nes $700 \& 729$

(267-A) control element - MN 108

Location - north face of shield

(270) control element - 1/8" Belfield (F.0.)

$\underline{\mathrm{IRC}-12}$

Recelver - Foxboro C.C. Recorder Controller for use w1th Foxboro D/P cells

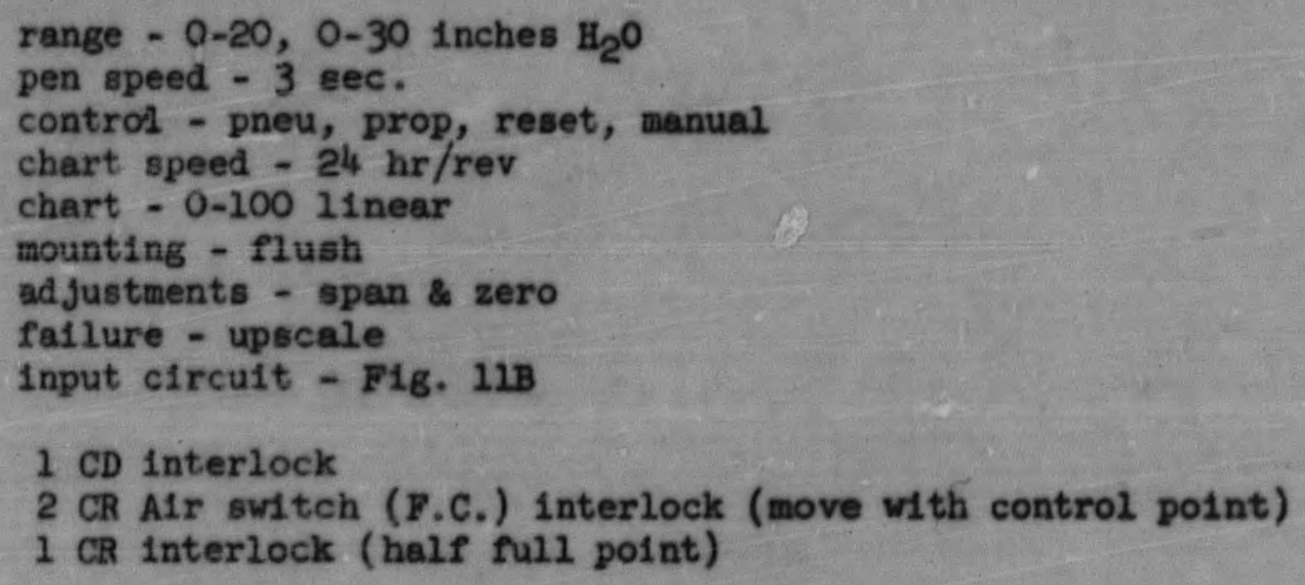

2 CR A1r switch (F.C.) Interlock (move with control point)

1 CR interlock (half full point)

Contacts: 1 CD interlock

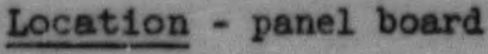

Transmitter - (6) Foxboro 30" D/P cell

Locat1on - south face of $\mathrm{D}_{2} \mathrm{O}$ cell

J.B. B $-36-40$

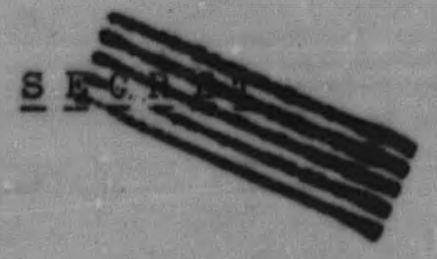

$-56-$ 


\section{TABLE 7 (CONTINUED)}

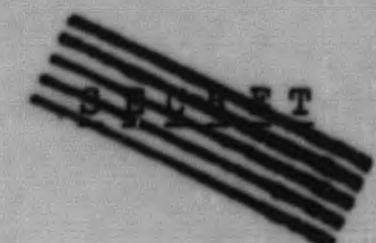

\section{IRC-12 (Cont1nued)}

Auxillary Equipment - (7) gas chamber ( $11 / 2^{\prime \prime}$ ss p1pe, 12" long)
(8) $1 / 8^{\prime \prime}$ Hoke vaive, extension handle
(155) control element - $1 / 8^{\prime \prime}$ Belfield (F.o.)

Mounting D1mensions: top of reflector top flange to top of D/P cell - $51 / 16^{\prime \prime}$ : top of D/P cell to full level - $95 / 16 "$ ": top of $\mathrm{D} / \mathrm{P}$ cell to zero level 39 5/16": top of D/P cell to full level $49^{\prime \prime}$.

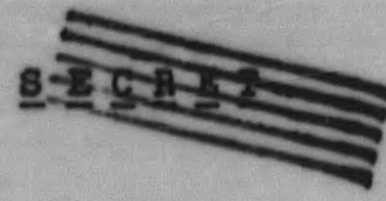


During a reflector dump without soup dump the pressure drops rap1dly, the $D_{2} O$ dumping in approximately 15 seconds. Th1s causes valve 267A to open wide and 270 to close. In time th1s would admit enough helium into the vessel to bring the now empty reflector back to approximately 1050 psi, requiring approximately 16 cubic feet of gas at this pressure. Upon refiling the reflector, th1s helfum would be blown 1nto the dump tanks through velve 270 . As the reflector 1s dropped for any shutdown of more than a few seconds duration, it is apparent that th1s loss of helium is very undesirable. Valve $267 \mathrm{~B}$ is therefore Interlocked through 1 ts solenold valve to the dump valve, 150 , so it closes on a dump and thus prevents flow of helium into the system. Th1s valve is further Interlocked with the reflector level controller so 1 t w11l be closed whenever the reflector is below the half full point (minimum operating level). This feature is necessary because the dump valve closes when the reflector is empty and hence without the level interlock valve, 2678 , would open and admit, helium. The rapid dump means an essentially adiabatic process, so the reflector pressure w11l drop to slightly over 100 ps1, permitting a pressure differentiel seross the core shell of 900 psi. Some $D_{2} 0$ should remain in the botton of the vessel when the dump valve closes so 1 ts vapor pressure vill soon reduce the differential pressure approximately 100 psi for rated operating temperature. However, the reactor w111 be operated during certain experiments at reflector temperatures below $175^{\circ} \mathrm{C}$. While the core should withstand the expected 900 psi differential, it is strongly recommended that a normal shutdown procedure require the reactor to be made subcritical by lowering the concentration and that the core pressure then be reduced to approximately 500 po1, allowing PRCA/D-10 to bring the reflector pressure to a corresponding value before the reflector is dumped. 


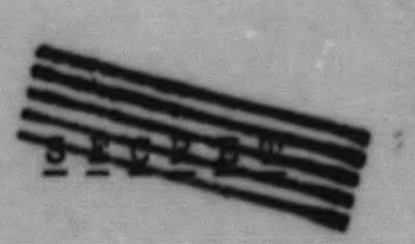

A core dump without reflector dump would apply a high differential pressure from the outside and might cause collapse of the core. Two precautions are provided to prevent this condition occurring. The reflector dump valve 13 Interlocked with the core dump valve as discussed later under "Safety circuit," so the reflector dumps simultaneously with the core. A back-up protection to care for this and also for a fallure in the hellum system is provided by connecting the reflector dump valve soleno1d to PRCA/D-10 so excessive differential pressure from reflector to soup w11l open the $\mathrm{D}_{2} \mathrm{O}$ dump valve and relleve the pressure.

Reflector level is controlled by LRC-12, consisting of a Foxboro $\mathrm{D} / \mathrm{P}$ cell and Dynalog controller. S1nce the connection of the $\mathrm{D} / \mathrm{P}$ cell is somewhat unorthodex it is alscussed in conjunction w1th Figure 18. The gas chamber, 7 , 1s provided to collect any gas wh1ch may get 1nto 11 nes 735 and 736 . Period1cally this gas can be bled off through valve 737 wh1ch 1s provided with an extension handle to the outside of the shield. If we assume an equilibrium condition with the reflector full and pressurized to $\mathrm{P}_{\mathrm{O}}$, the gas pressure in 7 being $P_{1}$, and vther pressures being due to vater column, the pressure on the top of the cell 1s:

$$
P=P_{1}+P_{3}-P_{2} \text {. }
$$

If the level drops to a point corresponding to a hydrostat1c pressure change of $\mathrm{P}_{4}$, the new pressure 1s:

$$
P^{\prime}=P+P_{3}-P_{2}-P_{4},
$$

or the change of pressure is $\mathrm{P}_{4}$. Thus, since the other side of the cell is maintalned at $P_{0}$, the differential pressure change corresponds to the change of level. It is seen that the 1nitial gas pressure, $P_{1}$, does not affect the instrument provided 1t does not cause the 11quid level to drop below 1ine 735 .

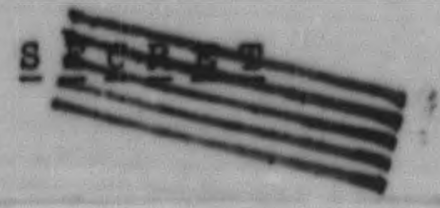

$-59-$

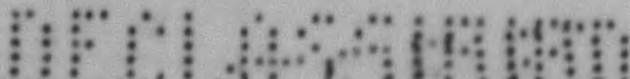




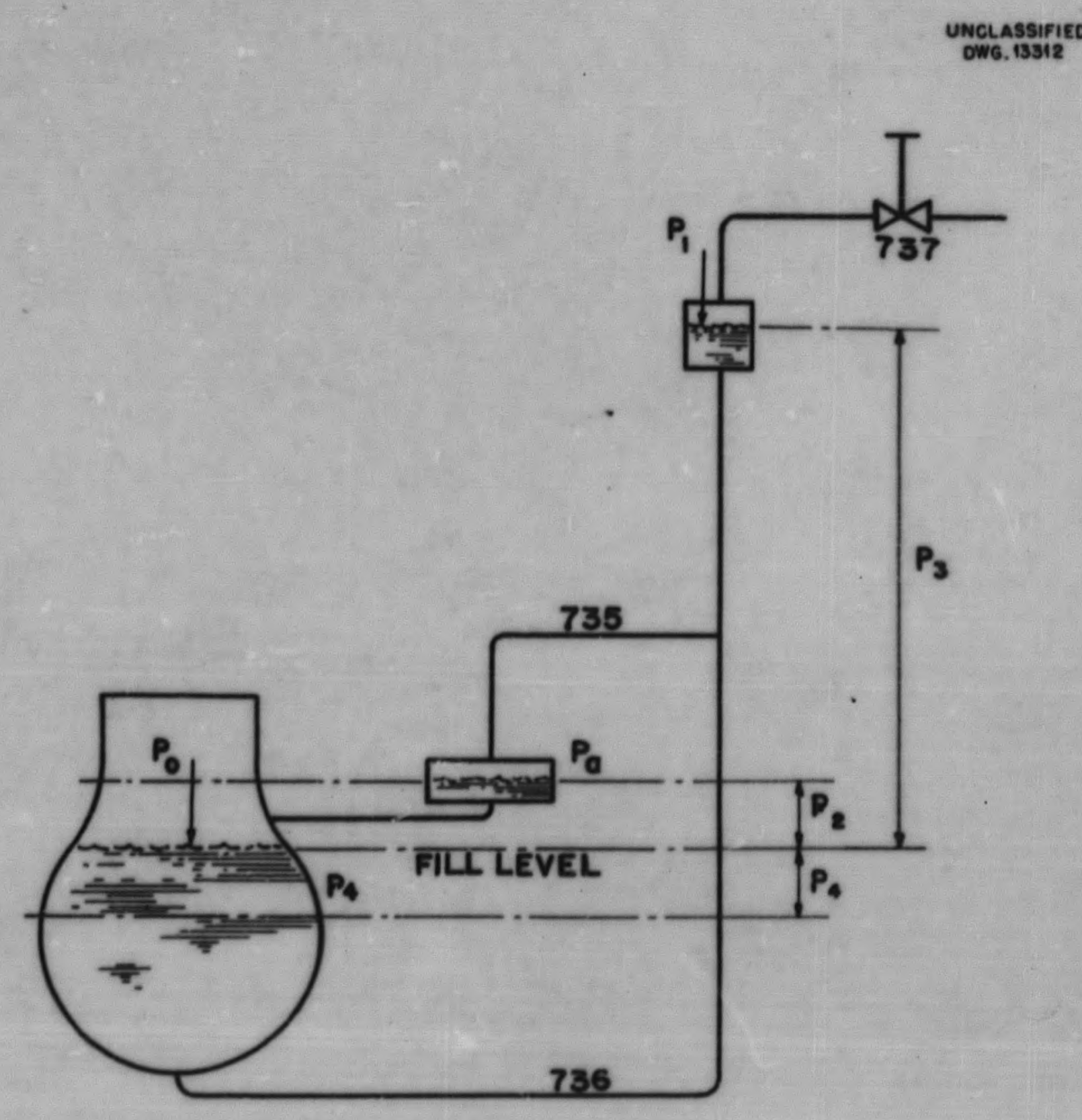

Fig. 18-Reflector Level

$-60-$ 


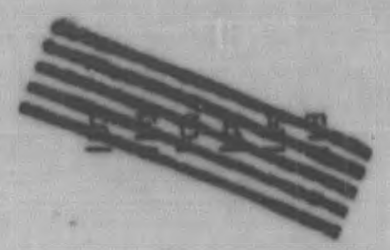

Line 855 of Figure 17 is provided to remove condensate from line 734 . Junction 11 or Figure 17 must be above the maximum water level because the instrument ind1cations reverse if this junction is submerged.

The controller is provided with a proportional air control and several electrical contacts. The control point may be set at the instrument by the operator, subject to a lower limit of a half full reflector. Th1s limit is provided by a blocking pin at half scale so the operator cannot run the reactor without sufficient reflector for safety. Excess $\mathrm{D}_{2} \mathrm{O}$ is bled off through valve 155, which is actuated by the air signal when the level is too h1gh. The pulsafeeder pump is controlled by two electrical contacts so it is started if the level falls to the lover one and is stopped when it reaches the upper one. The details of the electrical controls are shown in the safety c1rcult. In addition to these contacts, two others are provided for control during a reflector dump. One Just below the half full point provides an interlock on the helium valve, $26 \mathrm{~TB}$, as discussed above. The remaining contact 18 a lower limit control which operates the solenold of the dump valve, 150 , to close this valve before the reflector is completely empty.

Several other instruments are provided on th1s system, but do not serve as controls. PA47 and PA76 are pressure switches on the helium supply to give an alarm on the annunciator if trouble develops in this supply. PI80 is a pressure gage giving the absolute pressure in the reflector.

\section{Reflector Temperature}

The reflector temperature 18 maintained at the desired value by circulating the $D_{2} \mathrm{O}$ througin a heat exchanger whose cooling water is controlled by valves 310 and 313. The 1nstrument connections are showa in Figure 19, and the specifications, are given in Table 8 . Reference to the complete flow sheet

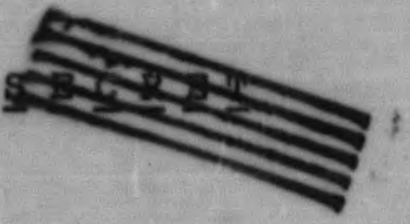
$-61-$

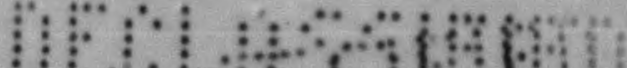


FFicial USE onLY

DWG 13313

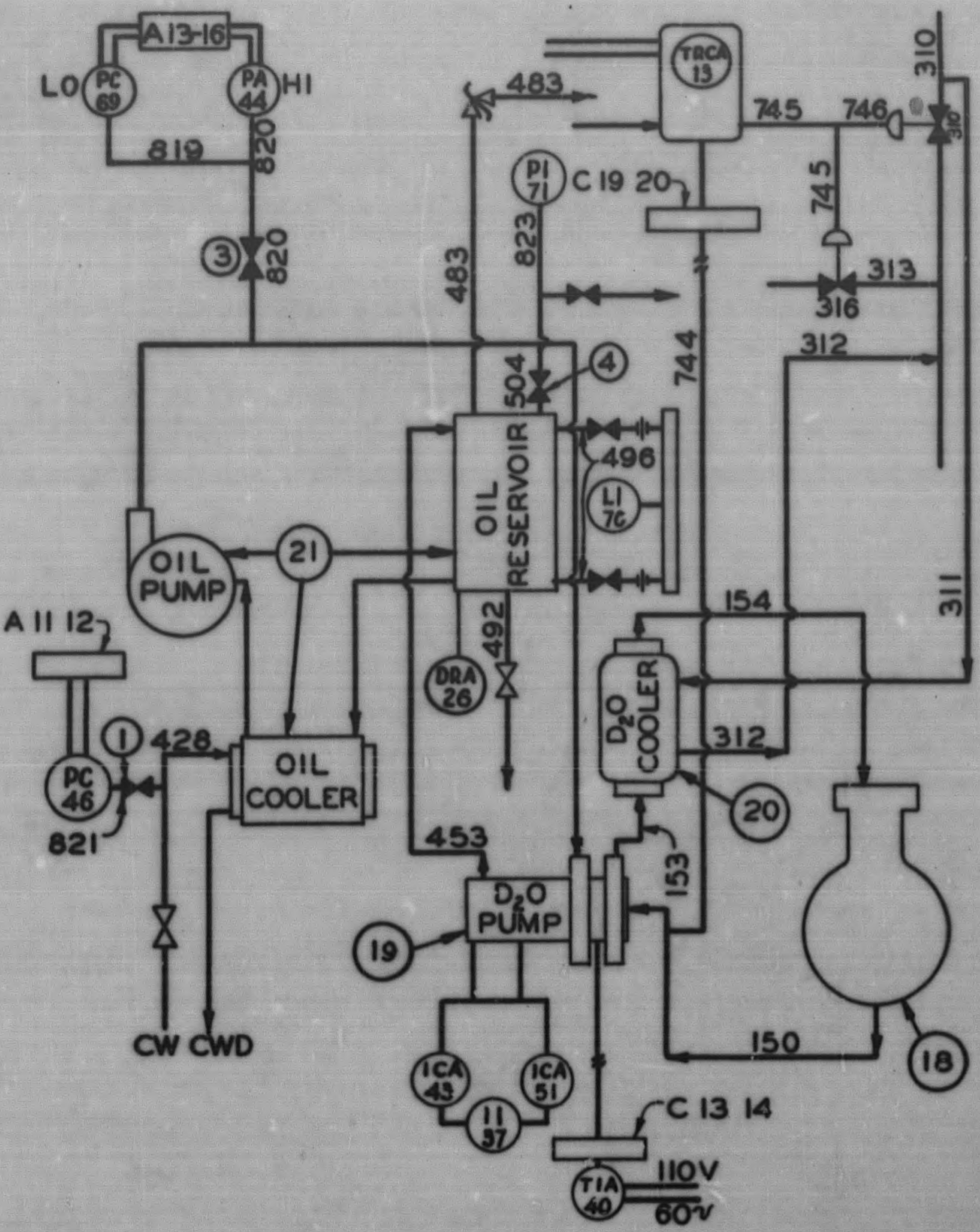

Fig. $19-\mathrm{D}_{2} \mathrm{O}$ Circulation

$-62-$

:

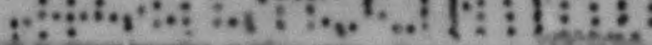




\section{TABLE 8}

\section{TRCA-13}

Recelver - Brown C.C. A1r-0-1ine Controller

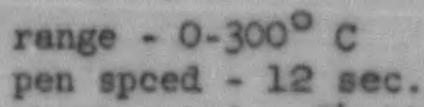

Contacts: 1 CR aiarm (F.0.)

Location - panel board

Transmitter - I.C. couple \& T.C. vell

Location - 11ne 152

J.B. $C_{1}-19,20$

Auxillary Equipenent - (313) control element $1 "$ ME val ve, line 313

(310) control element $11 / 4 "$ MH valve, line 310

\section{$\underline{\text { II-37 }}$}

G.E. Ammeter

$$
\begin{array}{r}
\begin{array}{r}
\text { range }=0-5 \text { amps } \\
\text { scale }-0-50 \text { amps }
\end{array} \\
\text { Location - panel board }
\end{array}
$$

TIA -40

Recelver - Symplytrol Indicator Pyrometer

$$
\text { range }-0-500^{\circ} \mathrm{F}
$$

Locat1on - panel board

Contacts: $1 \mathrm{CD}$ alarm

Transmitter - I.C. couple, surface adaptor

Location $-\mathrm{D}_{2} \mathrm{O}$ circulating pump

J.B. $C_{1}=13,14$ 


\section{TABLE 8 (CONTINUED)}

$\underline{\mathrm{ICA}-43}$

G.E. Under current relay

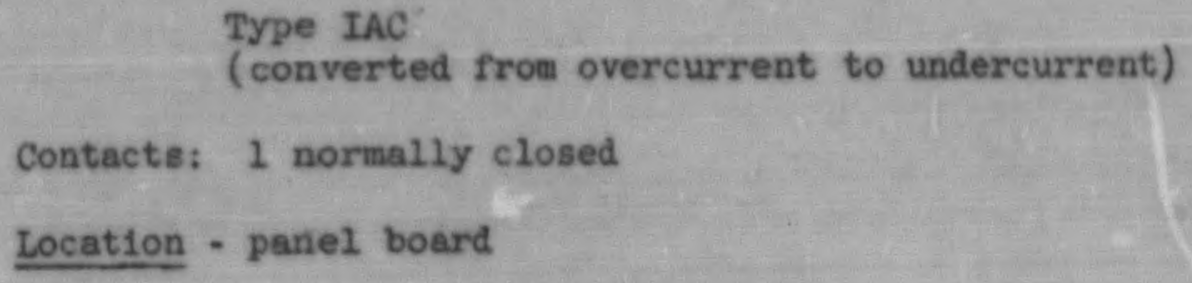

$\underline{\text { ICA-51 }}$

G.E. Overcurrent relay

Type PJC

Contacte: 1 normally closed

Location - panel board

$\underline{P A-64}$

Receiver - Mi pressure switch 0-300 psi

Location $-D_{2} \mathrm{O}$ oil pump platform

Contact: $1 \mathrm{CD}$ alarm

J.B. $A_{1}=13,14$

Auxil1ary Equipment - (3) $1 / 4^{\prime \prime}$ brass needle valve, 11 ne $\$ 20$

$\underline{\mathrm{PC}-46}$

Receiver - MH pressure switch 0-150 ps1

Location $-\mathrm{D}_{2} \mathrm{O}$ o11 pump platform

J.B. $A_{1}-11,12$

Contact: 1 CR interlock

Auxillary Equipment - (1) 1/4" brass needle valve

$\underline{\text { PCA }-69}$

Rece1ver - MH pressure switch 0-300 psi

Location $-\mathrm{D}_{2} \mathrm{O}$ oil pump platform

J.B. $A_{1}=15,16$

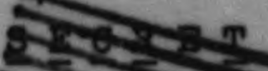

$-64-$ 


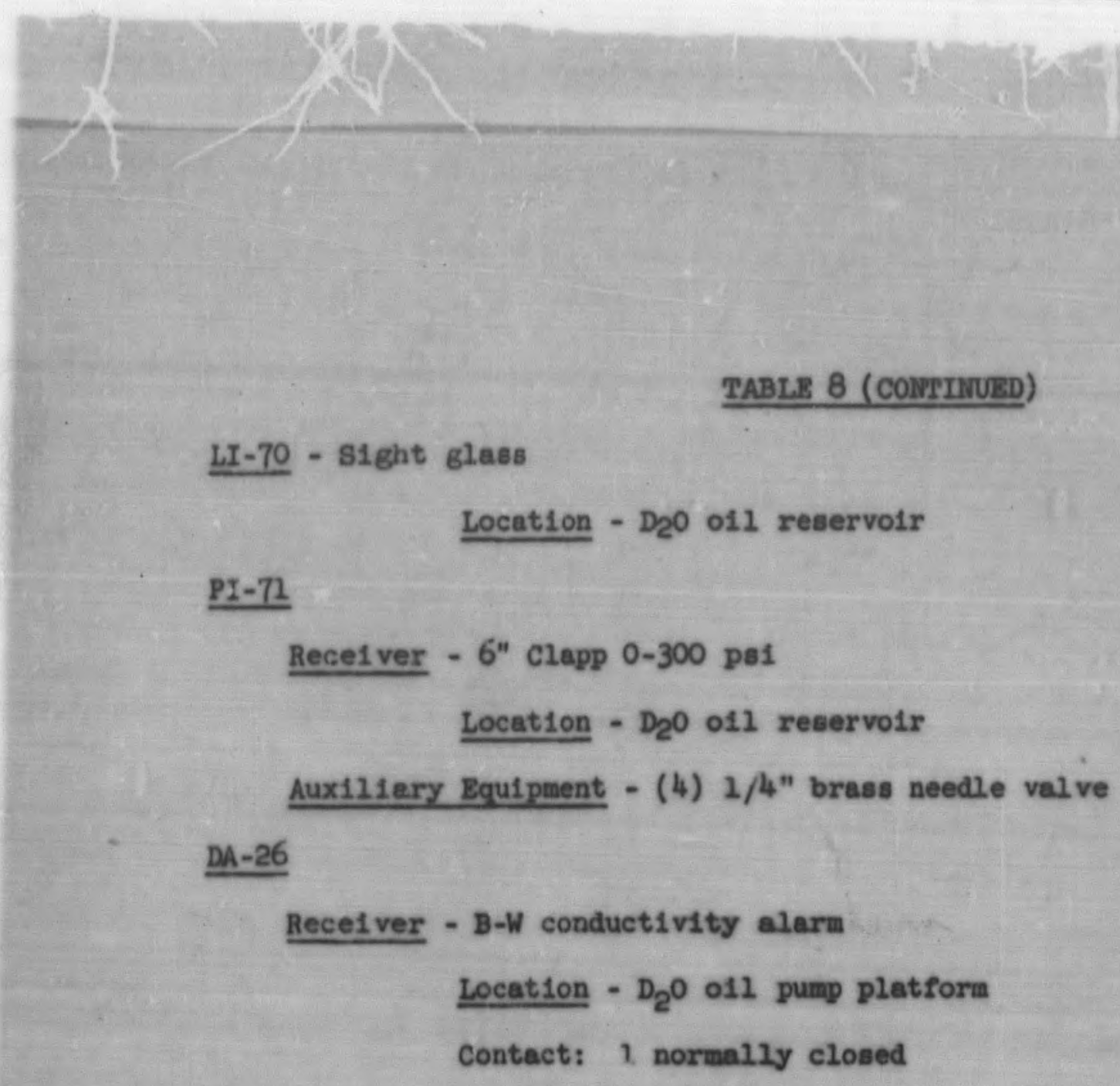

-65-

(1) 


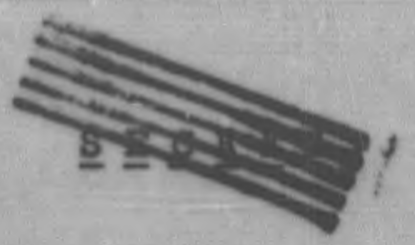

of Figure 4 will show that the cooling water 1s supplied by the feed water pumps of the reactor heat exchanger, thus the heat removed from the $\mathrm{D}_{2} \mathrm{O}$ is used to preheat the feed vater. The temperature is cetermined by a thermocouple in Iine 152 connected to a Brown c1rcular chart controller. The pneumatic control signal from this actuates valves 310 and 313 . If both of these valves are closed the flow through the $\mathrm{D}_{2} \mathrm{O}$ heat exchanger will be determined by the demand of the soup heat exchanger. This condition holds if this feed water demand is just right to maintain the correct $\mathrm{D}_{2} \mathrm{O}^{\circ}$ temperature. If the flow to the main heat exchanger $1 \mathrm{~s}$ too low the $\mathrm{D}_{2} \mathrm{O}$ temperature rises and the controller opens valve 313 , allowing additional flow through the $\mathrm{D}_{2} \mathrm{O}$ exchanger. If the soup heat exchanger demands more water thian that necesesxy to remove the $D_{2} O$ heat, the $D_{2} O$ cools and the controller opens valve 310 , thus allowing part of the flow of feed water to by-pass the $D_{2} \mathrm{O}$ exchanger.

The $D_{2} O$ elrculating pump is a1milar, except for size, to the soup c1rculating pump and the motor protection is the same as that provided for the soup pump with the exception of the pump leak dețection. The oll reservolr is equipped with a sperk plug at 1ts lowest point. Ttis plug is connected to a conductivity alarm, $\mathrm{DA26}$, so any $\mathrm{D}_{2} \mathrm{O}$ leakage w11 be detected when the $\mathrm{D}_{2} \mathrm{O}$ collects across the plug contacts.

\section{$\mathrm{D}_{2} \mathrm{O}$ Dump System}

The $\mathrm{D}_{2} \mathrm{O}$ inventory in the dump tanks is monitored by a loed cell similar to that discussed for the soup dump tenks. The connections are shown In Figure 20, and instrument data is given in Table 9.

There are no control Instruments on the cump system, but tempersture measurements are provided for at several points, as shown on the flow sheet.

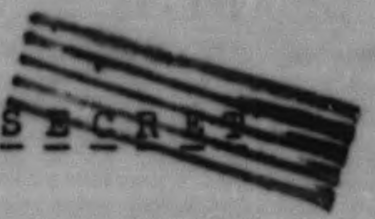


OFFICIAL USE ONLY ow6. 13314
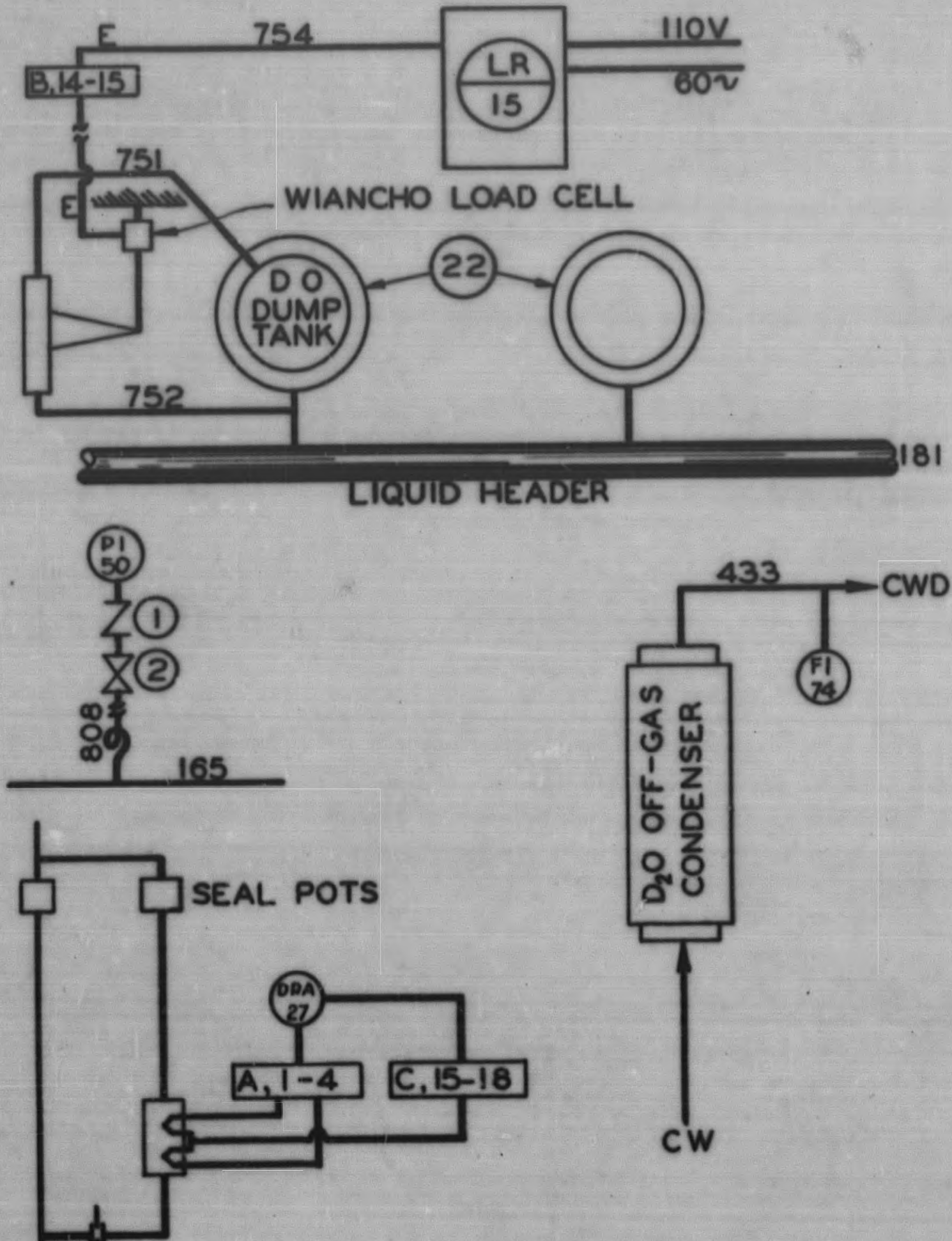

Fig. 20- $\mathrm{D}_{2} \mathrm{O}$ Dump System

$-67-$ 


\section{TABLE 9}

IR-15

Recelver - Foxboro dynalog c1rcular chart recorder for Wianco cell

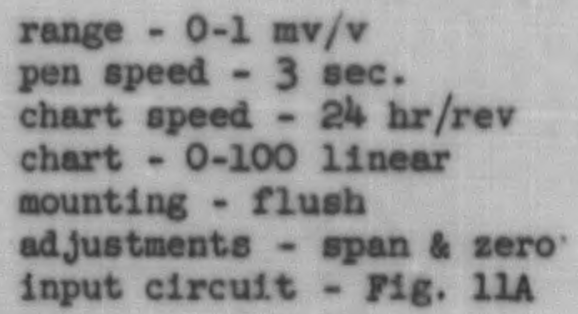

Location - panel board

Transmitter - Wianco cell, type 3FA15

Location - soup cell

$$
\text { J.B. }-B_{1}-41,45
$$

\section{DRA-27}

Recelver - Brown C.C. Recorder

$$
\begin{aligned}
& \text { range - 0-1 mv } \\
& \text { pen speed }-24 \text { sec. } \\
& \text { chart speed }-24 \mathrm{hr} / \mathrm{rev} \\
& \text { chart - 0-100 11near } \\
& \text { mounting - Plush }
\end{aligned}
$$

Location - panel board

Contacts - 1 CD elarm

Transmitter - platinum detector as built

$$
\begin{aligned}
& \text { Locat1on }-D_{2} 0 \text { cell } \\
& \text { J.B. } C_{1}-15-18 \text { (T.C.) } \\
& A_{2}-1-4 \text { (heaters) }
\end{aligned}
$$

Auxillary Bquipment - (1) and (2) Hg seal pots

(3) flat plate orifice, 11ne 168

\section{$\underline{\text { Pl-50 }}$}

Rece1ver - 6" Clapp, 0-500 ps1

Location - north face of shield

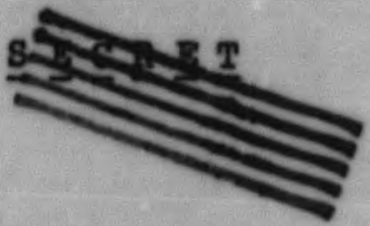

$-68$. 


\section{TABLE 9 (COMTINUED)}

P1-50 (Continued)

$$
\begin{aligned}
& \text { Aux111ary Equipment - (1) } 1 / 8^{\prime \prime} \text { check valve } \\
& \text { (2) } 1 / 8^{\prime \prime} \text { Hoke valve } \\
& \text { (3) Sylphon, line } 808
\end{aligned}
$$

FI-74

$12 \mathrm{gpm}$ water meter

Locat1on - east face of shield

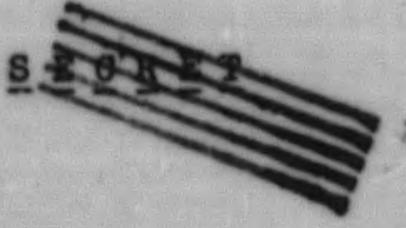

$-69-$ 
The thermocouples are connected to the 48-point prec1sion indicator on the operating console. These temperatures in conjunction with the water flows in the condensers, messured by water meters, give dats to compute vapor and gas flows In the off-gas system. Pressure measurement is prosided by a preesure gage, PI50, on the condenser header.

The catalytic recombiner temperature is a good indicator of the $D_{2}-O_{2}$ percentage in the hellum orf-gas. If the recombiner were perfectly insulated its only coolant would be the hellum flowing through 1t, while 1ts source of heat would be the recombination of the deuterium and oxygen. The resultant catalyst temperature would then be an excellent indication of the net effect of these two processes. While the recombiner 1nsulation is not perfect, the temperature is expected to yield an accurate determination of gas composition. The unit will be calibrated for this purpose before installetion.

As a check on the recombiners a deuterium detector is being developed and will be instailed in the off-gas line 168 as 1tem 94 (Fisure 4). The basic detector 18 a Davis hydrogen detector which is essentially a platinum filament operated at about $500^{\circ} \mathrm{C}$ and having a thermocouple attached so its temperature may be determined. The platinum serves as a catalyst for the recombination of hydrogen and oxygen, and is in turn heated by the reaction. This r1se of temperature is a measure of the amount of recombination. To apply this device to the present system it must be modified to operate over a vide range of flow rates, ranging from a low of a few $\mathrm{cc} / \mathrm{minute}$ due to helium valve leak- age up to 15 scfm during a dump. To compensate for variable cooling with variable flow, a second filament of a non-catalytic material is used and 1 ts thermoccuple connected in opposition to that of the platiaum. Tests indicate that alumel is one of the more suitable materials for this, but due to

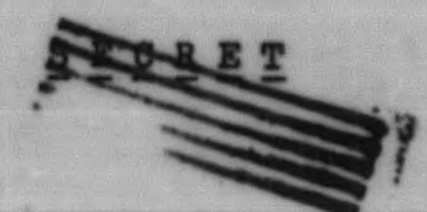
$-70-$

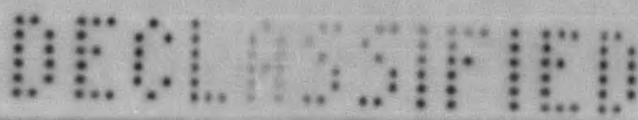




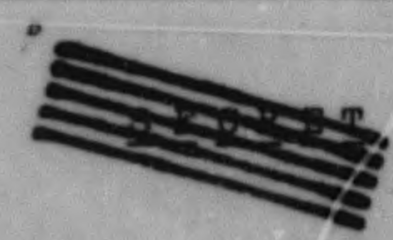

differences in emissivity of it and plat1num it does not compensate over the full range of flows. The rate of flow will therefore be controlled by use of mercury seal pots and orifice as shown in Figure 20. Pot 1 is set for a elightly h1gher pressure than 2, so for low flow rates the flow is entirely through the detector, while for high flows the orifice restricts the detector flow so most of the gas flows through pot 1. An experimental curve of the flow characteristics of the detector is shown in Figure 21.

The vacuum break provided between the hellum supply and the offgas line is a standard acetylene regulator backed by an instrument-type pressure regulator set to maintain a low gage pressure in the off-gas line. Th1s relieves the vacuum formed after a duap has occurred and the vapor pressure has dropped due to the condensers and cold traps. The sezl pot in the off-gas line is set to relleve at slightly above this regulated pressure.

\section{Steam Instrumentation}

Two auxillary sources of steam are provided, one the house bollers and the other the electrically-heated $40 \mathrm{kw}$ high pressure boller. The valving for these is shown in F1gure 4, and except for safety interlocks the control is manual. The interlocks are discussed later under "Activity Monitors."

The instrumentation of the $40 \mathrm{kw}$ boiler is given in Figure 22 and Table 10. The level instrument is a Brown 20 inch mercury manometer connected to a Brown flow recorder. The high and low level contacts of the recorder are connected to the boller heater circult so the heaters cannot operate if the level is outside the limits. PCA45 is a pressure switch also connected to disconnect the heaters if the pressure gets too high. The steam pressure is indicated by a conventional pressure gage.

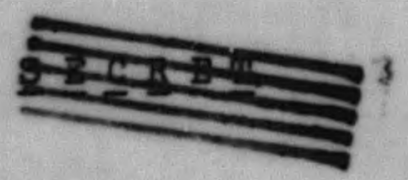




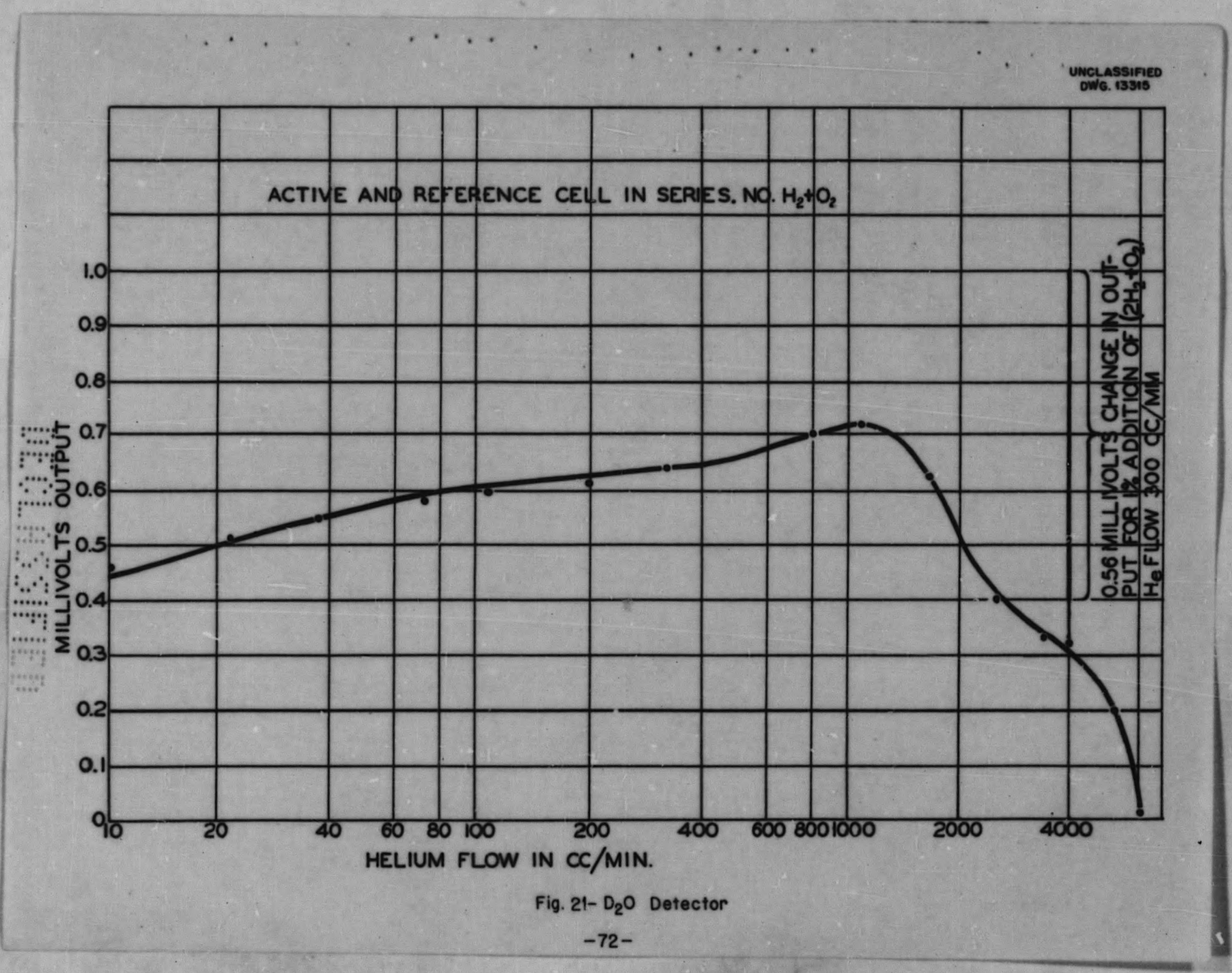




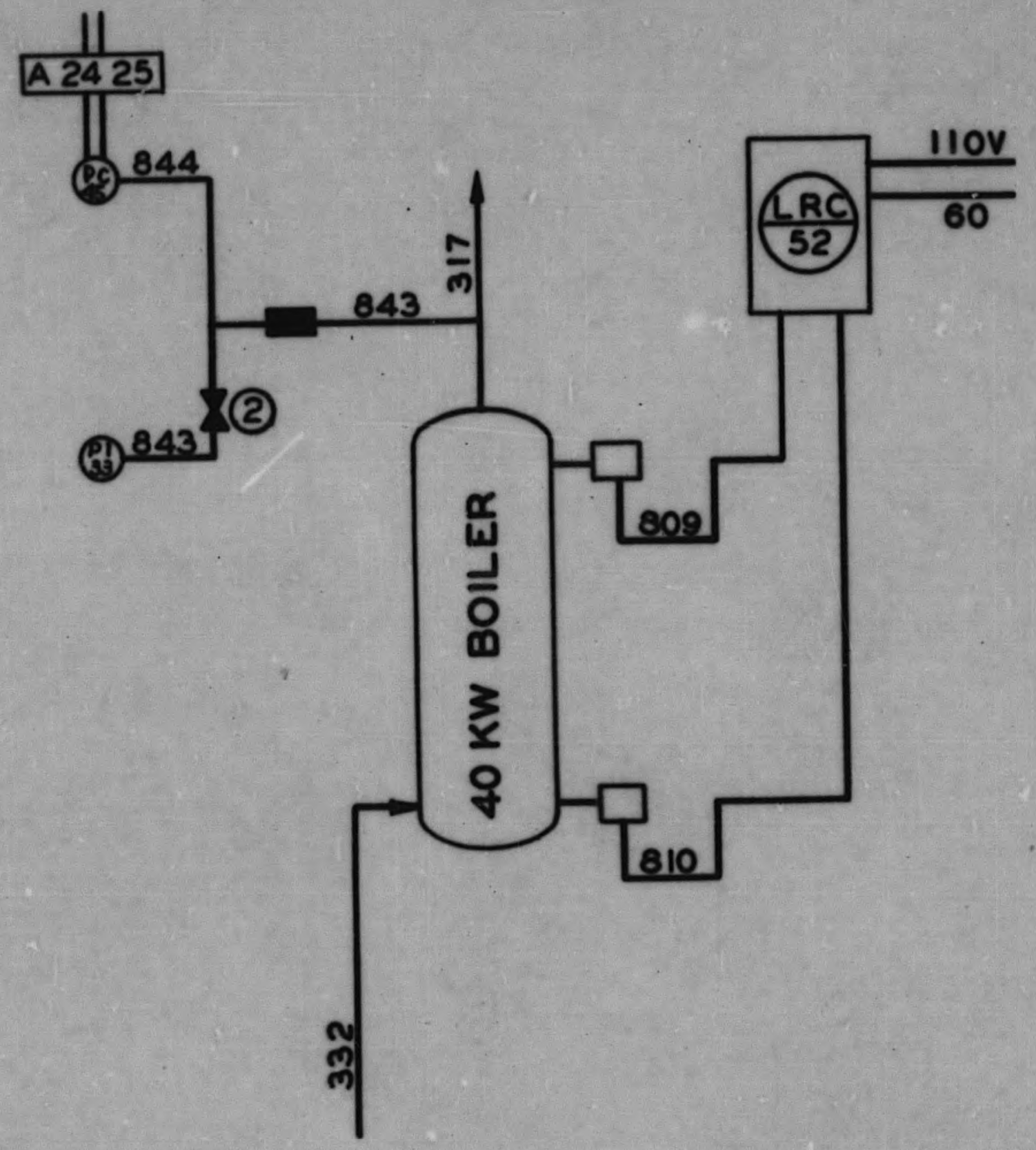

Fig. 22-40 kw Boiler 


\section{TABLE 10}

\section{PI-33}

Rece1ver - 6" Clapp 0-1000 psi

Location - vest face of shleld

Aux1liary Equipment - (2) 1/8" Hoke valve, line 843

(I) autoclave check valve, line 843

PCA -45

Recelver - 0-1500 Mercold prossure switch

Locat1on -.west face of shleld

Contact: $1 \mathrm{CD}$ high alarm

J.B. $A_{1}-24,25$

1 CD j.nterlock (p1ckup on annunciator)

$\underline{\text { IRC }-52}$

Recelver - Brown Hg Manometer

$$
\begin{aligned}
& \text { range } 0-20 \text { Inches } \mathrm{H}_{2} \mathrm{O} \\
& \text { chart speed }-24 \mathrm{hr} / \mathrm{rev} \\
& \text { chart - 0-100 11near } \\
& \text { mount - flush } \\
& \text { fallure - upscale } \\
& \text { J.B } A_{1}-26-29
\end{aligned}
$$

Auxiliary Equipment - (3) \& (4) Seal pots (connect to $40 \mathrm{kw}$ bo1ler w1th A106 3/4" pipe)

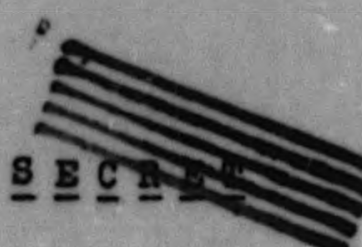




\section{$\underline{\underline{s}}$}

The several pressure indicators on the steam system shown in F1gure 4 are stendard and data is given in Table 11 . The steam pressure and Nlow from the heat exchanger are metered by a regular pressure connection and a Brown mercury manometer transmitter across an orifice in the steam line connected to a two-pen Brown recorder, PR31. Th1s instrument gives the delivered power of the reactor.

PC30 is a pressure switch to provide an interlock for the safety circult in the event of a line break.

Valve 347 is interlocked through a time delay with valve $316 \mathrm{~B}$ so the condensate return may be switched from the heat exchanger Iine to the bullaing line when the steam source is switched.

\section{Cold Traps}

The cold traps for the soup and $\mathrm{D}_{2} \mathrm{O}$ systems have identical controls as shown in Figure 23. Besides the compressor sontrols, the traps themselves are provided with various control valves. The refrigerant is regulated by float valves rather than expansion valves and may be shut off from elther trap by the solenold valve for defrosting. The connection of the electrical switches and the soleno1ds is arranged to prevent both traps being defrosted at the same time. However, both may be refrigerated at the same time. Thermostats on the cold traps are connected in parallel with the valve position relay contacts to sound an alarm if gas is velved through a varm trap.

\section{Alarm Annunciator and Mimic Panel}

The alarm annunciator uses a circuit similar to that used in the Mar, as shown in Figure 2h. The panel contains fifty-four stations to provide the alarms show in Table 13 and necessary spares for future needs. The operation
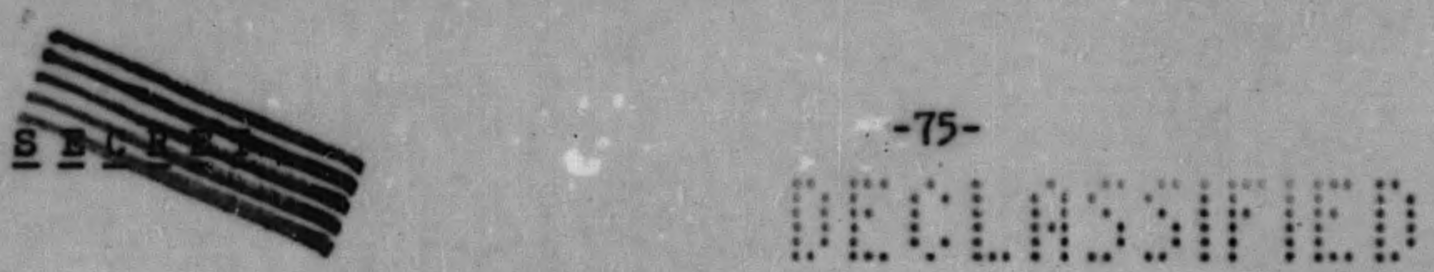


\section{PC-30}

\section{TABLE 11}

Recelver - 0-1500 ps1 MH pressure sw1tch

Location - west face of shield

Contacts: $1 \mathrm{CR}$ - interlock

J.B. $A_{1}-44,45$

Auxil1ary Bquipment - 1/8" Hoke valve

PI-3I

Recelver - Brown C.C. Recorder (2 pens)

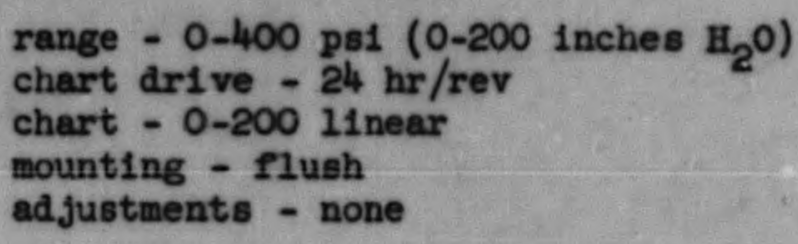

Transmitters - Hg manometer with electric transmission

$$
\begin{array}{r}
\text { range - } 0-20 \text { Inches } \mathrm{H}_{0} \mathrm{O} \\
0-200 \text { Inches } \mathrm{H}_{2} \mathrm{O}
\end{array}
$$

Aux1liary Equipment - Autoclave check valve (11ne 840) Flat plate orifice (11ne 316 ) (steam capacity $3000 \$ / \mathrm{hr}$ )

\section{$\underline{P I-32}$}

Rece1ver - 6" Clapp, 0-600 psi

Location - turbine gage board

Auxillary Equipment - 1 autoclave surge check valve

1 1/8" Hoke

1 sylphon, 11ne 841

\section{FI-53}

Flat plate orifice and manometer

Location - turbine gage board 


\section{TABLE 11 (CONRINUED)}

$: \underline{1-77}$

Rece1ver - 6" Clapp 0-1000 ps1

Location - turblne gage board

Auxillary Equipment - $1-1 / 8^{\prime \prime}$ Hoke valve

$\underline{\text { P1-34 }}$

Rece1ver - 4 1/2" Clapp, 0-75 ps1

Location - on turbine gage board

Aux1l1ary Equipment - 1 - 1/4" brass needle valve

$\underline{P l-35}$

Rece1 ver - 4 1/2" Clapp, 0-100 psi

Location - west face of shleld

Auxillary Equipment - $1-1 / 8$ " check val ve

1 - 1/4" brass needle valve

1 - Sylphon, 11ne 834

P1-39

Mece1ver - 6 " $\mathrm{CL} \mathrm{pp}, 30^{\prime \prime}$ vacuum to $50 \mathrm{psi}$

Location - turbine gage board

Aux1l1ary Equ1pment - $1-1 / 4^{n}$ brass needle valve

1 - $1 / 8$ " check valve

1. Sylphon

P1-41

Rece1ver - 6" Clapp, 0-100 ps1

Locat1on - west face of shield

Auxiliary Equipment $-1-1 / 4$ " brass needle valve

1 - 1/8" check valve

1 - Sylphon, line 805

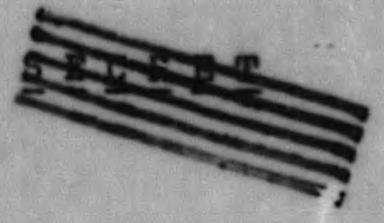

$-77-$ 


\section{TABLE 11 (COMTINUED)}

\section{P1-42}

Rece1ver - 4 1/2" Clapp, 0-1000 psi

Location - turbine gage board

Auxillary Equipment $-1-1 / 8^{n}$ Hoke val ve

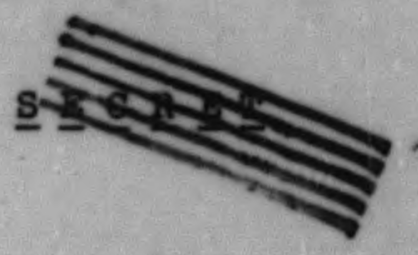

$-78-$

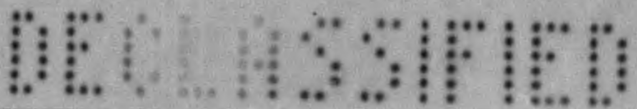




\section{TABLE 12}

TRA-3

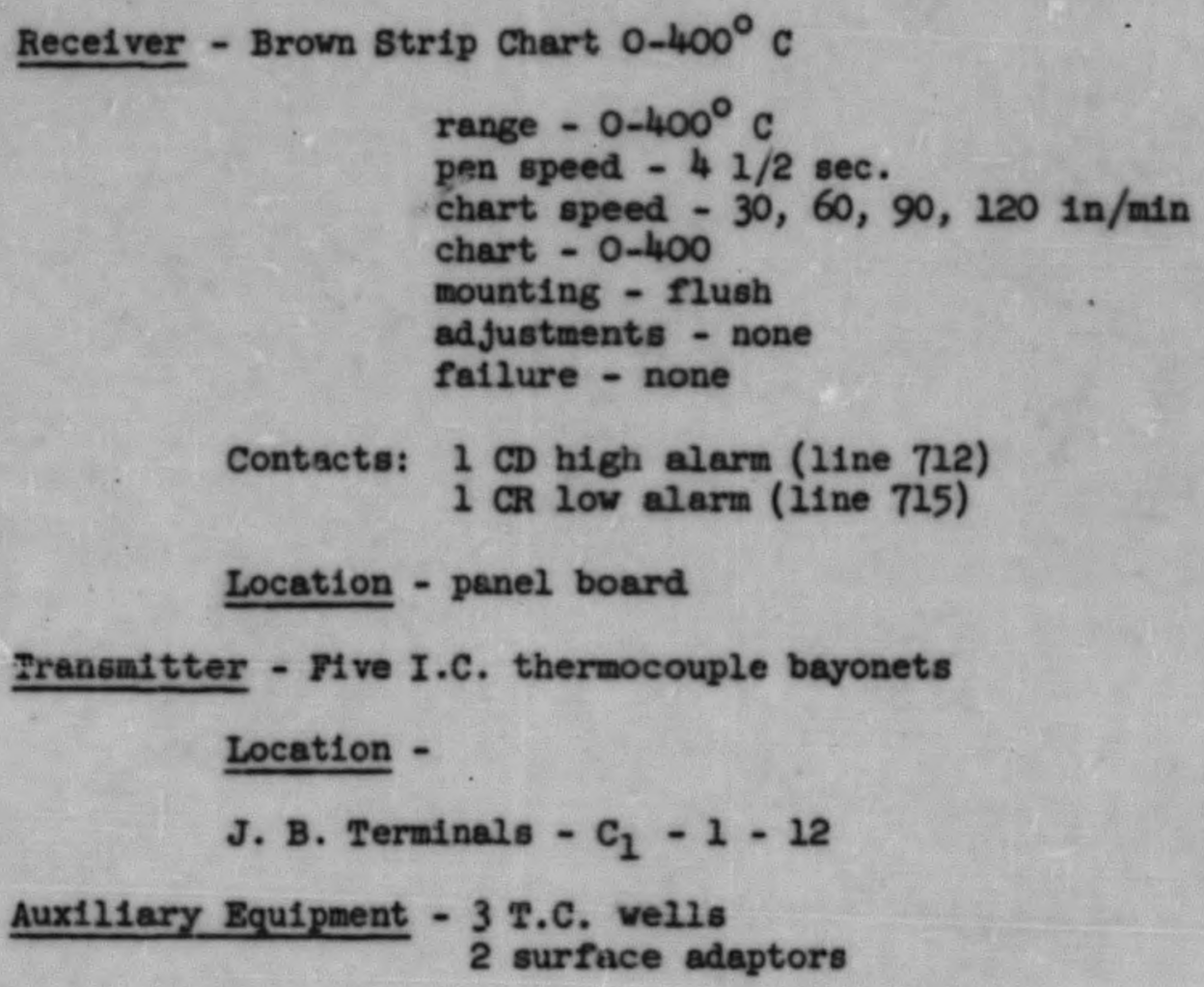

$\underline{\text { TI }-17}$

Receiver - Brown Precision Indicator (48 points)

$$
\begin{aligned}
& \text { range - } 0-300^{\circ} \mathrm{C} \\
& \text { speed }-12 \mathrm{sec} . \\
& \text { scale }=0-300 \\
& \text { mount - flush }
\end{aligned}
$$

Locat1on - panel board

Transmitter - I.C. couples 


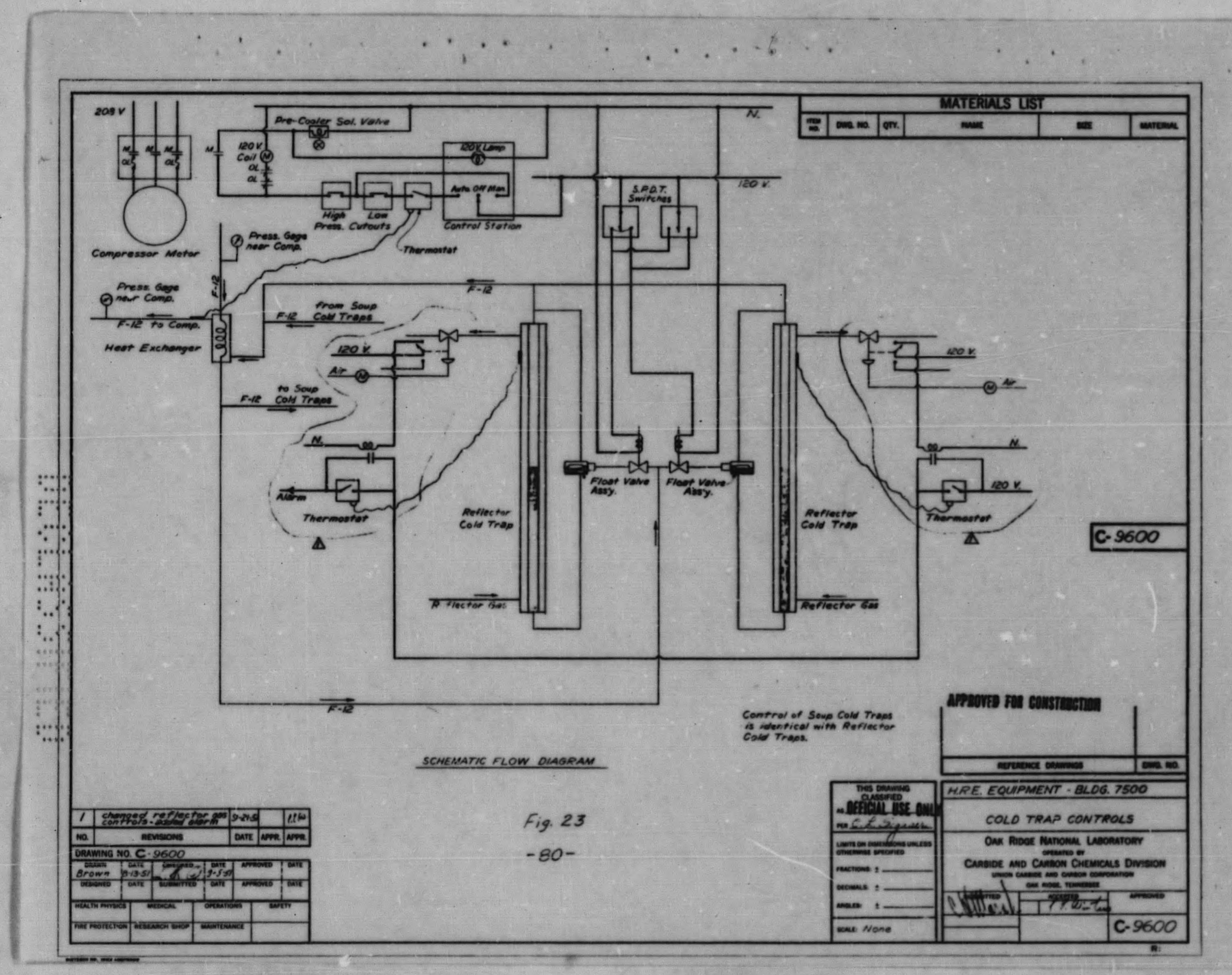


CIRCUIT DEENERGIZED

NO TROUBLE

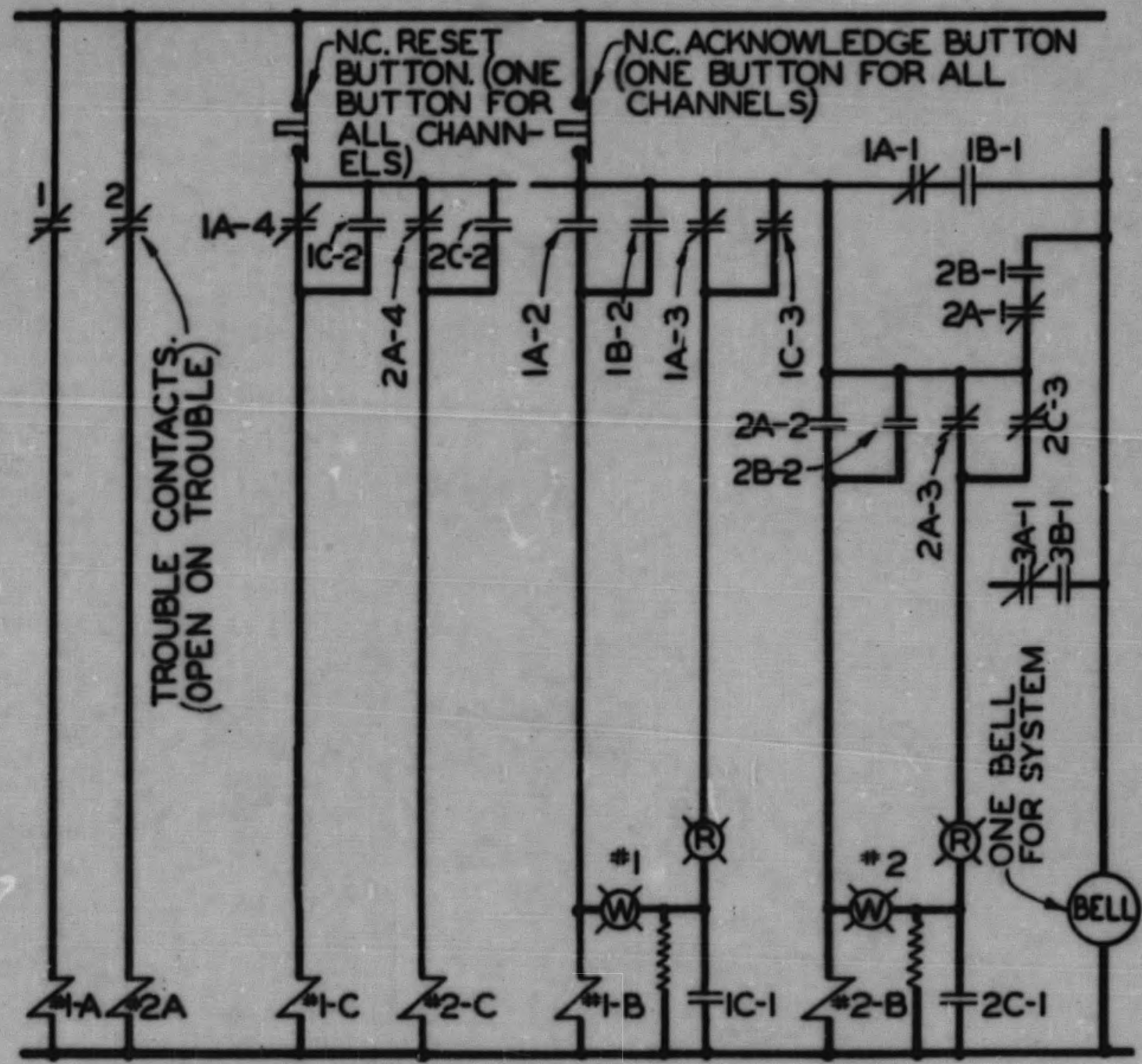

Fig. 24-Alarm Annunciator 
TABLE 13

Inst.

Ho.

Code

Pressurizer level

$\begin{array}{ll}\text { PRCA } & \text { Soup pressure } \\ \text { TRA } & \text { Multipoint soup temp. }\end{array}$

TIA Soup temp.

PRCA/D Soup- $\mathrm{D}_{2} \mathrm{O}$ differential press.

TRCA Reflector temp.

TIA Soup pump temp.

ICA Soup pump overcurrent

PA

$\begin{array}{ll}20 & \text { PCA } \\ 22 & \text { ICA } \\ 26 & \text { DAA }\end{array}$

$\begin{array}{ll}20 & \text { PCA } \\ 22 & \text { ICA } \\ 26 & \text { DAA }\end{array}$

011 pressure to soup pump

$10 \mathrm{kw}$ pressure

26 DaA

29 TRCA

40 TIA

43 ICA

4h PA

45 PCA

$47 \quad$ PA

Soup pump - undercurrent

$\mathrm{D}_{2} \mathrm{O}$ detector - $\mathrm{D}_{2} \mathrm{O}$ pump o11

$\mathrm{D}_{2}$ detector - $\mathrm{D}_{2} \mathrm{O}$ of $\mathrm{P}$-gas

Pressur1zer temp.

$\mathrm{D}_{2} \mathrm{O}$ pump temp.

$\mathrm{D}_{2} \mathrm{O}$ pump undercurrent

011 to $D_{2} 0$ pump

$40 \mathrm{kw}$ pressure

51 ICA

69 PCA

72 PCA

76 PA

Helium to reactor

- $\mathrm{D}_{2} \mathrm{O}$ pump overcurrent

Lo oll pressure

soup pump cooling oll

79 PRCA/D

23 QRC

24 QRC

25 QRC

66 QRC

68 QRC

90 PCA

89 PCA

87 PA

Hellium to reactor

Soup off-gas flow

Monitrons: Steam

\section{$\mathrm{D}_{2} \mathrm{O}$ off-gas}

soup oll

B1dg. vent

Stack

\begin{tabular}{ll} 
High Alarms & Low Alsarms \\
\hline
\end{tabular}

$\mathrm{x}$

$\frac{x}{x}$

$\mathbf{x}$
$\mathbf{x}$

$\mathbf{x}$

$\mathrm{x}$

$\underset{x}{x}$

$\frac{x}{x}$

$\mathrm{x}$

$\mathbf{x}$

$x$

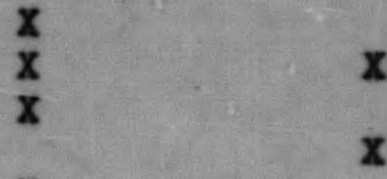

$x$

$x$

$x$

$\mathbf{x}$

Builaing air pressure

Builaing water pressure

Oxygen pressure

Pulsafeeder flow

Catalyst (soup) temp.

$\begin{array}{lll}62 & \text { QIC } & \text { Catelyst }\left(\mathrm{D}_{2} \mathrm{O}\right) \text { temp. } \\ 63 & \text { PRC } & \text { Safety } \\ 59 & \text { QRC } & \text { CRM } \\ & & \mathrm{D}_{2} \mathrm{O} \text { pump stop }\end{array}$

$x$

$\mathbf{x}$

$\mathbf{x}$

$\mathbf{x}$
$\mathbf{x}$
$\mathbf{x}$

$x$

$\mathrm{x}$

$\mathrm{x}$

$\underset{\mathbf{x}}{\mathbf{x}}$

$\begin{array}{ll}\mathbf{x} & \mathbf{x} \\ & \mathbf{x} \\ & \mathrm{x} \\ \mathrm{x} \\ \mathrm{x} & \mathrm{x} \\ \mathbf{x} & \mathrm{x} \\ \mathbf{x} & \\ \mathbf{x} & \mathrm{x}\end{array}$

$x$
$x$
$x$
$x$
$x$
$x$
$x$
$x$

$-82-$

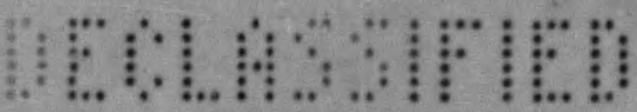


of the circuit can be seen by reference to Figure 24 and Table 14. Basically, the alarm Indication consiste of two lights and a bell. For normal operation of the monitored c1rcuit both lamps are dim, thereby giving a continuous check on the lamps. Occurrence of trouble changes both lamps to bright and sounds the bell. Acknowiedgment btops the bell but leaves the red light on. If the trouble clears, the bell stops and the red light is turned off; the white, however, stays on bright. After the operator has made the necessary log entries the circuits are returned to normal by prescing the reset button.

A simplifled flow sheet showing the principal process 11 nes and the remotely operated valves is used for a mimic panel mounted above the center panel board in the control room. The valve operators have SPDI microswitches mounted on them so the switch is operated by movement of the valve stem. These switches In turn control the two 11ghts, white and Ereen, at each valve symbol on the mimic panel. The open or closed position of all valves is thus indicated by the appropriate light on the board. For valves which may be throttled the degree of operation is indicated by the pressure gage on each air switch.

Adattional supervision of the over-all condition of the process equipment is provided by a microphone and speaker system. Carbon microphones are located in each of the major compartments and contact microphones are mounted on the two circuiating pumps. These are connected to suitable amplifiers and a speaker on the operating console. A selector switch permits the operator to monitor any microphone at will. Mock-up tests have shown this system to be especially useful tn plcking up incipient failure of pump bearings.
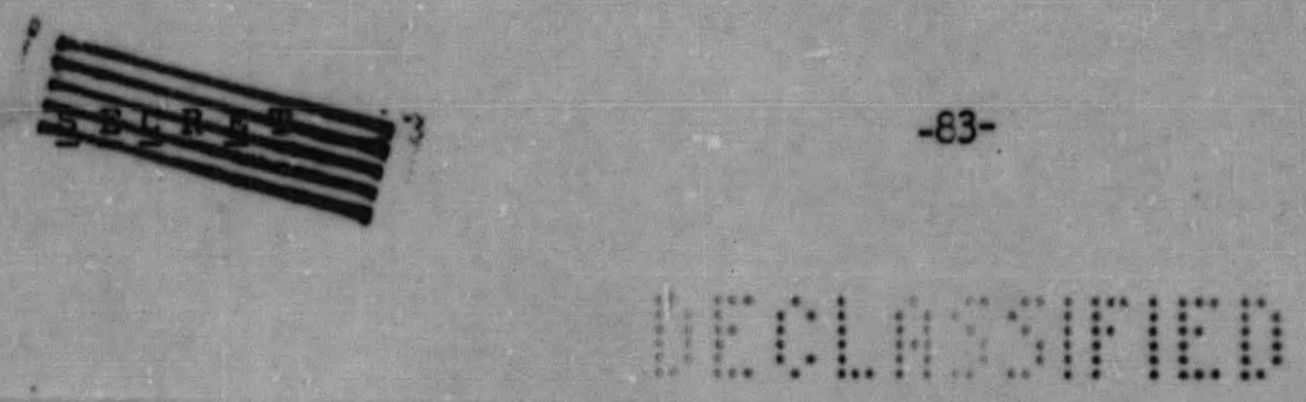


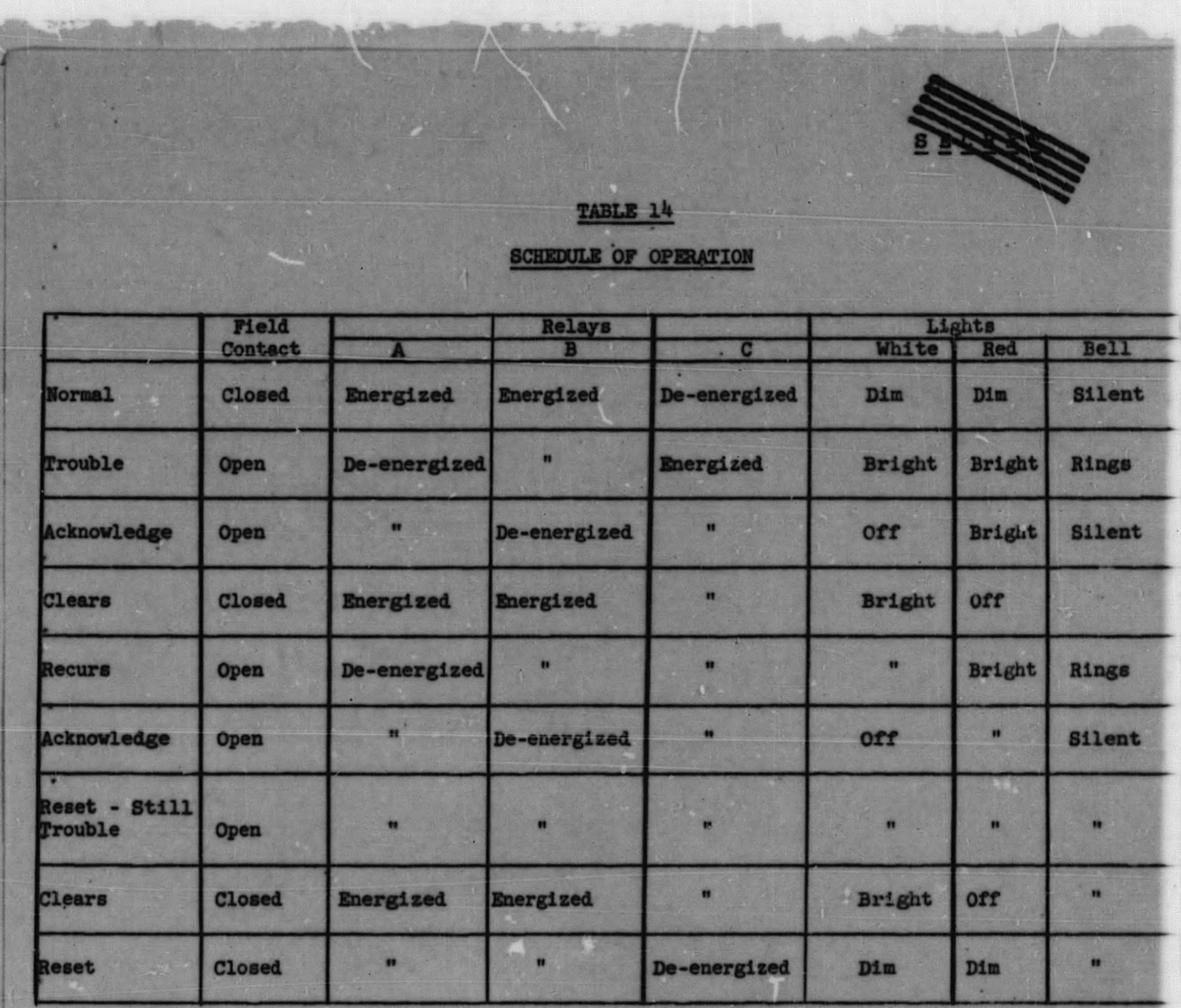
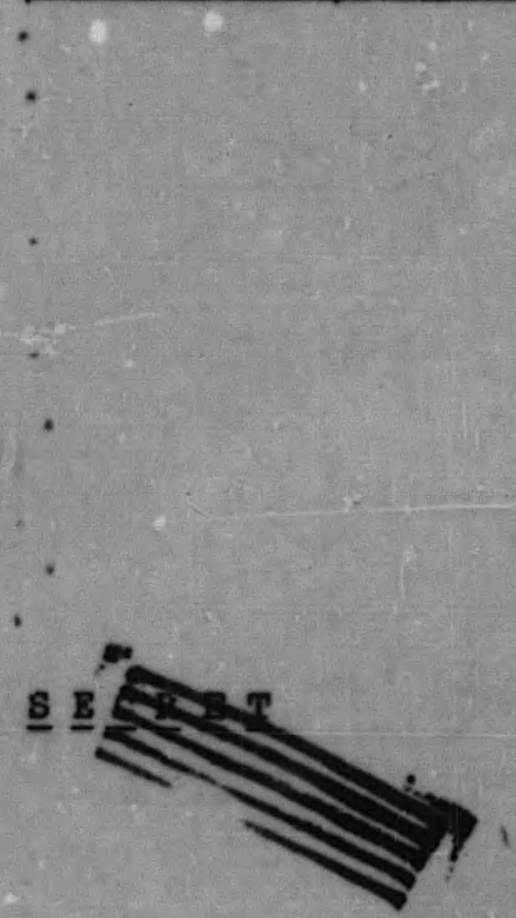

$-84-$

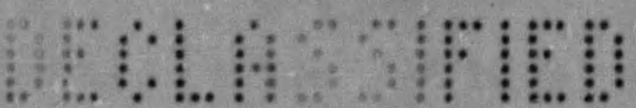




\section{Safety Circuit}

The various reactivity controls, nuclear instruments and process instruments are connected in an interlocked circuit so start-up and shutdown, elther routine or scram, can occur only in an orderly and safe fashion. The experimentel nature of th1s reactor has necessarily made this safety circuit somewhat more cormplicated than would be necessary if the reactor were designed solely as a power producer. It is also realized that in some instances the design may appear to "lean over backwards," but it seems best to include as many safety features as possible, and later remove them if operating experience proves them unnecessary. The goal has been to so interlock functions that the reactor can always shut down to a safe condition at any point in 1ts start-up or operation; to arrange the components so they are adequately protected against faulty operating conditions; and to sssure that abnormal nuclear conditions, operating conditions harmful to equipment, or fallure of components w1ll shut the reactor down in an orderly manner.

The block diagrams of the operating sequences for start-up or power increase are shown in Figure 25. For operation the console power switch must, of course, be unlocked, thereby energizing the various controls. Filling of the core with dilute soup and soup circulation through the heat exchanger are the only operations permitted without a cocked safety rod. This rod is raised through an Independent circuit and 1ts clutch and limit swltches are then used through appropriate relays to assure that the rod is up before the reactor can be trought critical.

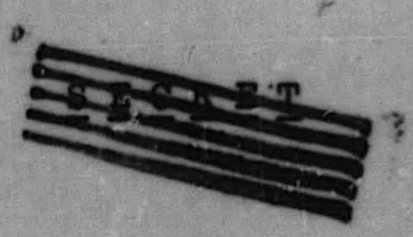




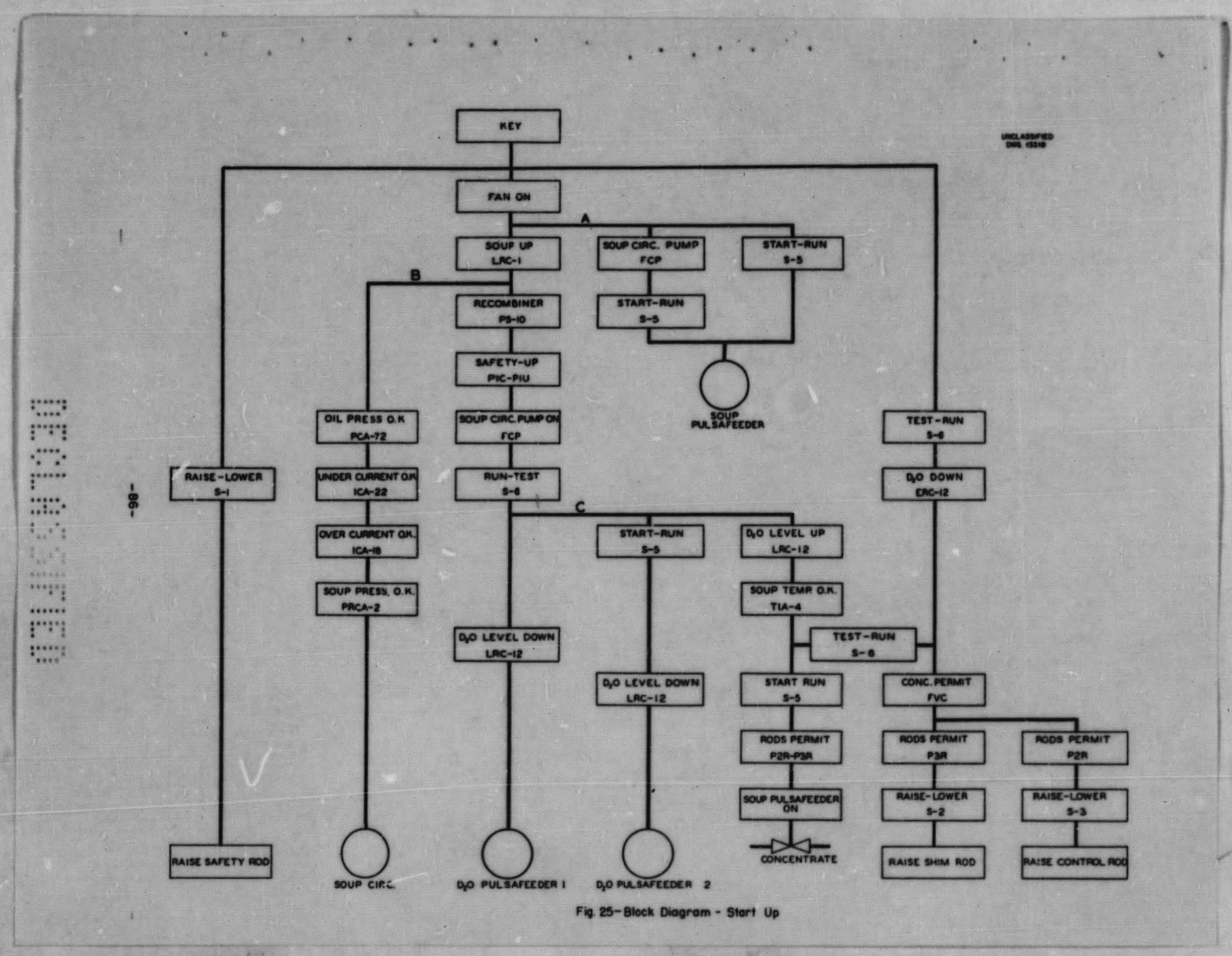


The soup pumps may be operated if the stack fan is on. During operation the pulcafeeder pump should not operate unless the c1rculating pump is also operating to assure a uniform concentration throughout the system. However, for Initial filling of the core the pulsafeeder must operate alone. This and other "start" functions are provided by the "start-run" switch. In the diagram, switch positions are indicated by underlining the proper word. With this sultch In the "start" position the pulsafeeder pump may be operated without the c1rculatIng pump but other contacts on the switch block operations which might make the reactor go critical. As soon as the core system is filled and pressurized the c1rculating pump may be started and the pulsafeeder will operate with the switch In the "run" position. 011 pressure and motor current of the c1rculating pump must be within satisfactory limits in order to protect the motor. Soup pressurization is necessary to protect the bearings and 1mpeller of the circulating pump, the manufacturer's specifications calling for a positive head of 200 ps1, thus putting a lower limit on the pressures at which experiments may be performed.

With tile soup circuit functioning, the safety rod cocked and recombiner on, the reflector may be brought up to operating level. During the initial filling of the reflector the "start-run" sultch is in the "start" position, thus allowing both the $1 \mathrm{gpm}$ and $2 \mathrm{gpa}$ pumps to operate. Once the level reaches the point of the reflector level 1nstrument (LRC-12) both pumps are automatically stopped and the $2 \mathrm{gpm}$ one will not restart unless manually started, and then only if the switch is still on "start." The 1 gpm pump maintains level under control of the level instrument.

Not only must the reflector be up, but the soup temperature must be at the proper value before the soup may be concentrated or the shim and regulating rods moved. These three controls are interlocked so only one at a time may be

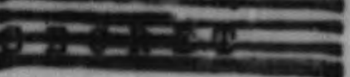

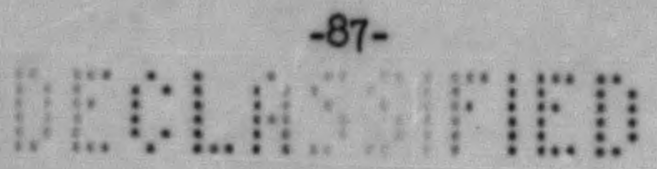


varied. Concentration is further blocked unless the soup pulsafeeder is operating, thereby preventing excessive build-up of concentration in the dump tanks. Concentration interlock is obtained by an overriding solenoid valve in the air Iine to the "concentrate" valve.

The reactor cannot reach criticality without the reflector up, so it Is safe to make tests of the rod drive circuits when the reflector is empty. Th1s facility 1s provided by the "test" position of the "test-run" switch through the bottom $11 \mathrm{~m} 1 \mathrm{t}$ of the reflector level instrument.

The block diagram of rigure 26 shows the numerous parallel paths by which the reactor may be shut down.

A manual shutdown may be made by lovering the rods with the motor drive, by releasing the magnet3, or by dumping reflector or soup. The rods may be run down individually or all together by using the appropriate motor switch. These varlous methods of shutdown give rise to different conditions and initiate different follow-up operations.

Motion of the ehim or regulating rods does not initiate any automatic sequence, but any lowering of the safety rod, whether by run-down or magnet drop, starts the $\mathrm{D}_{2} \mathrm{O}$ timer. Unless the operator manually blocks the timer, the $\mathrm{D}_{2} \mathrm{O}$ is automatically dumped at a f1xed time after the rod moves. This effectively ahuts the reactor down. The several signals which will automatically drop the rods and give this type scram are indicated on the block diagram.

There are several signals which Indicate a soup leak, and these cause Immediate dumping of the soup snd reflector, as vell as dropping of the rods and subsequent operations.

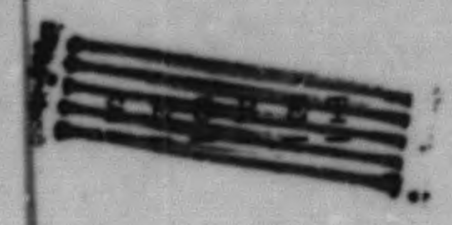

$-88-$

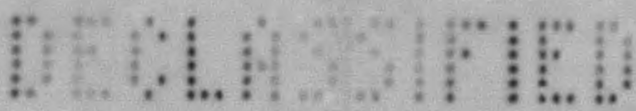




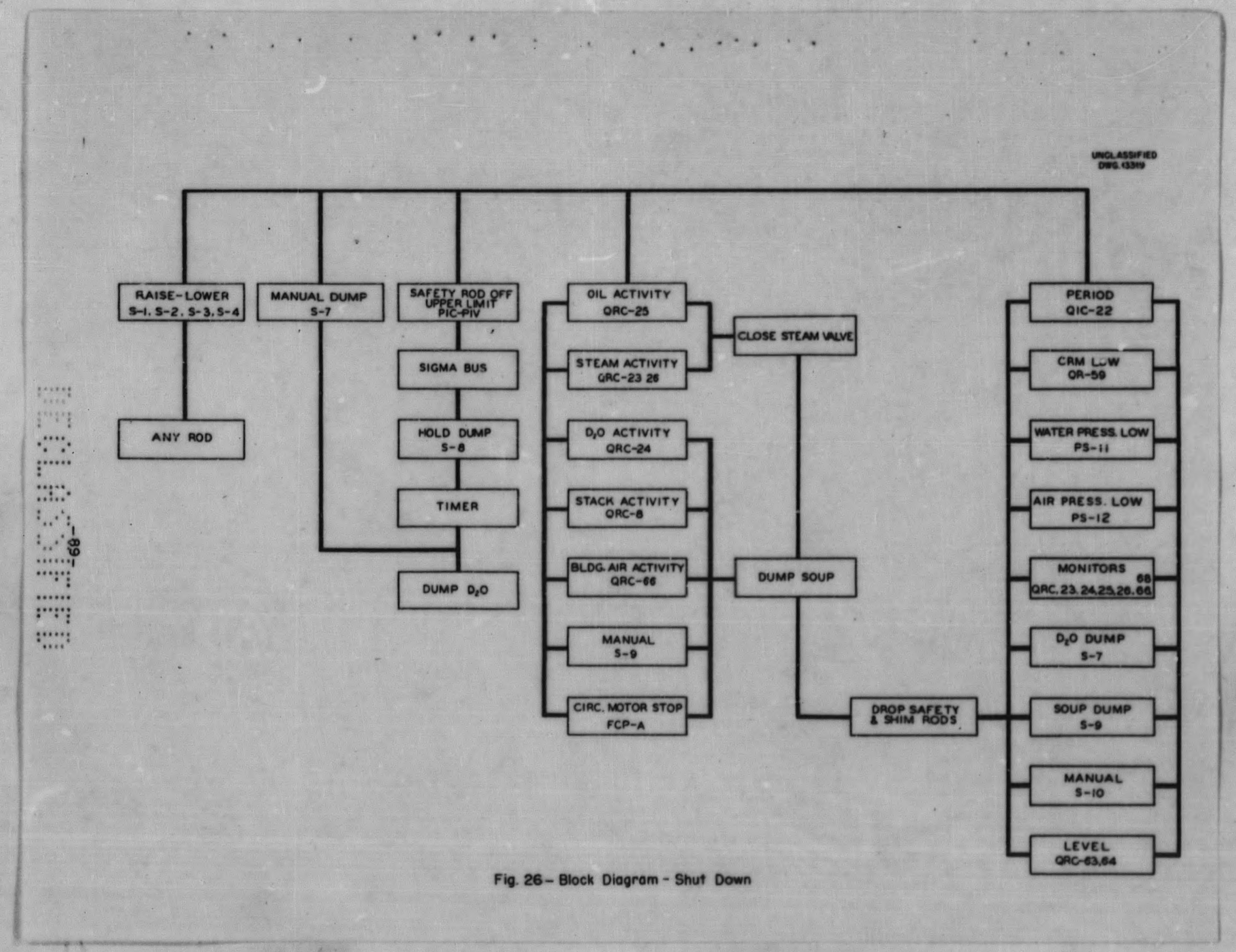




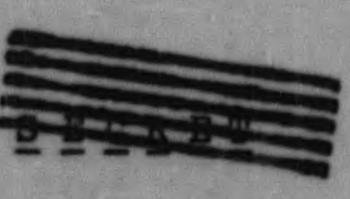

The details of the c1rcuits which provide the safety 1nterlocks are shown in Figure 27. The key to relay and instrument contact notation is given in Table 15. The exact functioning of the various relays is discussed in connection with the start-up and shutdown operations.

\section{Typical Operations}

Some discussion of the start-up, running, and shutdown of the reactor will serve to 1llustrate the operation of the safety circuits and, at the same t1me, present some of the considerations which dictated the particular solution to certain problems. There are possible variations in the procedures wh1ch may be used with the present 1nstrumentation and control. Furthermore, it is highly probable that operating experience will suggest future changes in the circuitry and procedures.

The reactor is assumed to be in a completely shutdown state, reflector and soup in their respective dump tanks and at amblent temperature, and the operation is started from this point.

The operations discussed are based on a conventional run as certain experiments will require modifications of the safety devices. While such a procedure is necessary in order to get the maximum 1nformation from the HRE, 1t is absolutely essential that some control procedure be established to assure safe operation. As a minimum requirement, no change should be permitted unt1l revlewed by the proper control and operation engineers; all such changes should ve recorded in a permanent log; and no start-up of any kind should be permitted without f1rst checking this log.

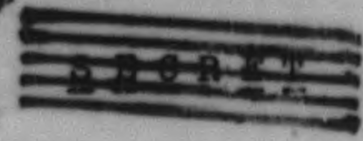




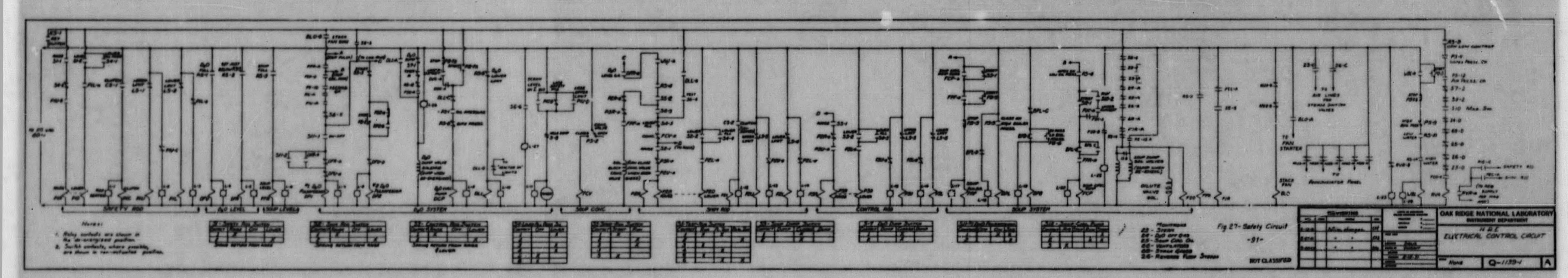


TABLE 25

SAFMIY CIRCUIT LEGEND

REKLAYS

Safety Rod: P1

$$
\begin{aligned}
& \text { PIR - raise rod } \\
& \text { PIC - clutch } \\
& \text { PIU - upper limit } \\
& \text { PIL - lower limit } \\
& \text { PID - lower rod }
\end{aligned}
$$

Shim Rod: P2

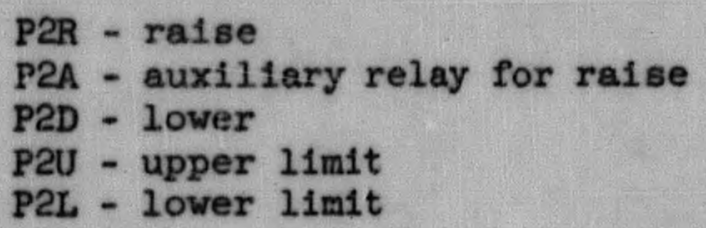

Control Rod: P3

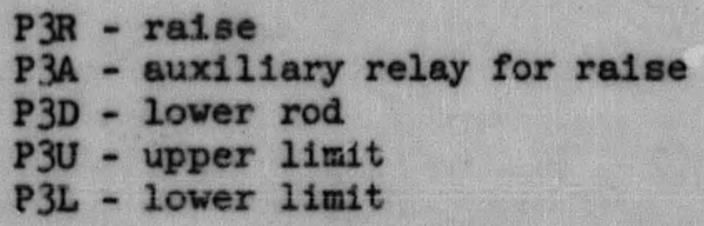

\section{Soup System: F}
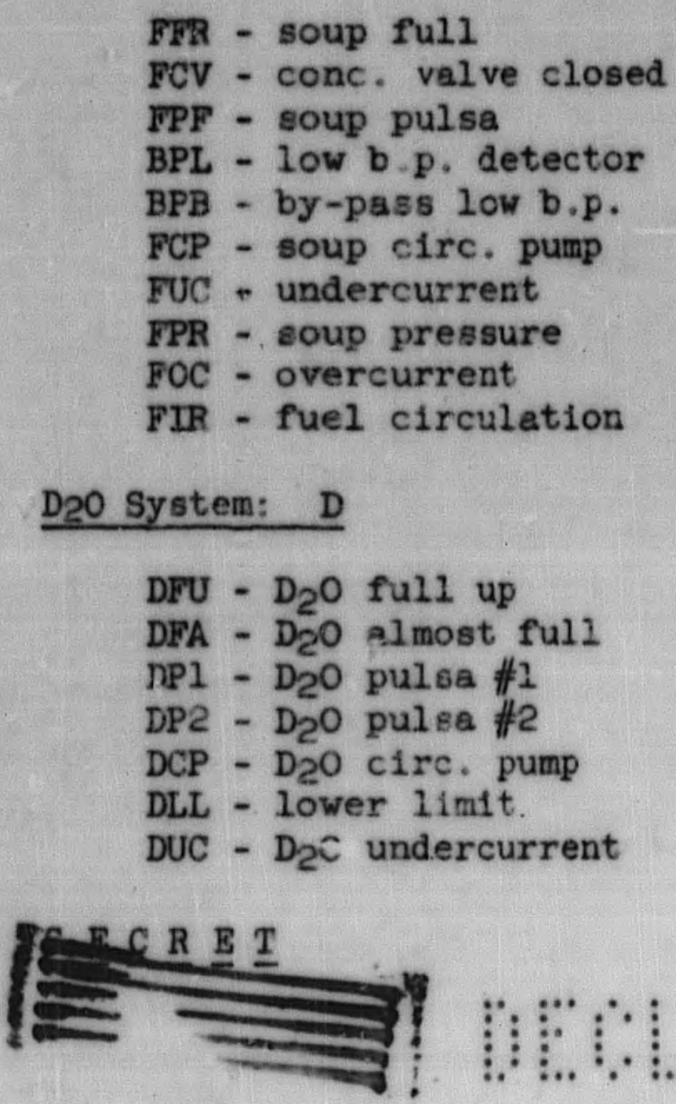

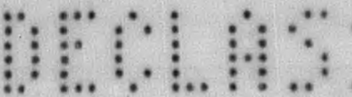

\section{Miscellaneous:}

$$
\begin{aligned}
& \text { WBL - water boller } 40 \mathrm{kw} \\
& \text { ROL - reactor on } \\
& \text { RVP - reg. volt supply } \\
& \text { BLO - stack fan }
\end{aligned}
$$

\section{Sw1tches:}

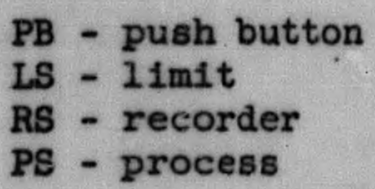


TABLE 15 (CONTINUED)

\section{CONTROLLER SWITCHES}

RS-1 Closes on $\mathrm{D}_{2} \mathrm{O}$ full, at the desired level. (In reflector)

LRC-12

RS-2 Closes on $\mathrm{D}_{2} \mathrm{O}$ almost full, just below RS-1.

IRC -12

RS-3 $\mathrm{D}_{2} \mathrm{O}$ lower limit. Closes when uncovered.

LRC-12

RS-4 Closes when some des1red value of soup temperature

TIA-4 10 reached. $\left(\sim 200^{\circ} \mathrm{c}\right)$

RS-5 Closes when core 1s full or soup. (Pressur1zer level)

RS-6 Opens when soup- $\mathrm{D}_{2} \mathrm{O}$ diff. pressure exceeds some value.

RS-9 Opens on too-low reading of CRM.

RS-10 Closes on too-low value of water level to $40 \mathrm{kw}$ water boller.

RS-11 Closes when soup pressure reaches some minimum required value. ( $\sim 200$ psi)

PRCA $/ D-10$

QR-59

LRCA -52

PRC-2

RS-12 Opens on some undesirably high value on safety recorder.

QR-61

RS-13 Opens on high soup temperature.

TIA-4

\section{PROCESS SWITCHES FOR HRE ELECTRICAL CONTROL CIRCUIT}

PS-1 Opens when o1l pressure to $D_{2} 0$ circulating pump drops below a desired value.

PS-2 Position of soup conc. valve. (Closes when valve closes)

PS-3 Opens on low steam pressure in maln stean boller. closed on normal operating pressure.

PS-4 Opens when o1l pressure to soup c1rculating pump drops below a certain desired value. (Close wher valve closes)

PS-9 Opens to too-high value of boller pressure in $40 \mathrm{kw}$ water boller.

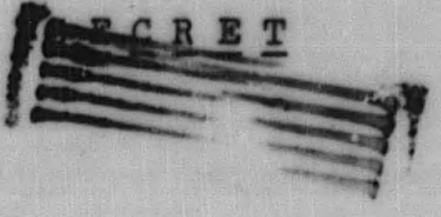




\section{TABLE 15 (CONTINUED)}

\section{PROCESS SWITCHES FOR BRE ELECTRICAL CONIROL CIRCUIT}

SW

ACTrON

INSTRUNIENT

PS-11 Opens on low cooling water pressure.

PS-12 Opens on low 1nstrament a1r pressure.

PS-13 Opens when $1 / 2^{\prime \prime}$ soup dump valve is open.

PS-14 C1oses when 1/2" soup dump valve 1s open.

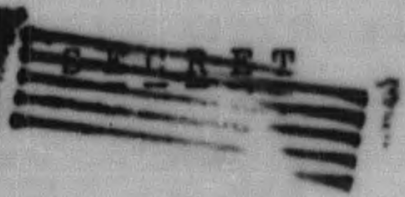

$-94-$

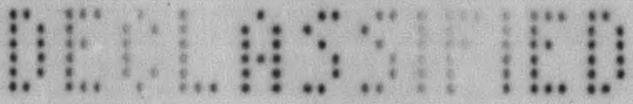


Menually-operated valves controlling varlous coollng vater flows and electrical switches controlling auxiliaries are set by the operator before startIng the reactor 1 tself.

Controlled motors and heaters are actually switched by magnetic contactors which are controlled by the relsys shown in the safety circuit.

The saiety rod is raised to the upper $11 \mathrm{mit}$ before any other normal operational step is taken. Th1s is indicated by clutch add upper 11mit switches and other controls interlocked through the proper relays, PIC and PIU.

A possible variation, as far as Interlocks are concerned, is to pump up the soup and even bring it to operating temperature before the safety rod is raised. In either case, the soup may be pumped up only when the stack fan is operating. As prevlously mentioned, the soup c1rculating pump must operate When the pulsafeeder does, in order to prevent excessive concentration differentials. For th1s discussion, we shall assume the rod is raised first.

The stack fan 1s one of the auxiliaries which 1s normally started before beginning operations so 1 ts interlock through relay BLO is satisfled. The soup may then be pumped up and brought to proper temperature and pressure. The "start-run" switch must be in the "start" position. The soup pulsafeeder control relay, FPF, is actuated by the push-button on the console and is locked In by the control relay contacts FPF-D. Dur1ng th1s pump-up process, the soup let-down valve is closed by the level controller until the level reaches the control polnt when LRC-1 throttles the let-down valve to maintain level at the proper point. If gas in the system is compressed in the pressurizer to exceed

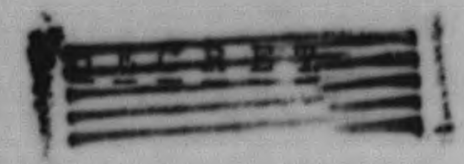


the operating pressure, the pressure controller, PRC-2, w11l open valve 125 to relleve the gas binding.

The next step is to pressurize the soup system. Th1s is accomplished by setting the temperature and pressure controllers, TRC-29 and PRC -2 , to the desired values and switching the $10 \mathrm{kw}$ botler heaters on.

As soon as the soup level and pressure are correct, the soup c1rculating pump may be started by actuating relay FCP through 1ts "start" button. Th1s relay is subject to several permissive controls - soup level up given by LAC-1 through relay FF, load within proper limits given by over and under current relays FOC and FUC, soup pressure h1gh enough to prevent pump damage given by PRC-2 through relay FPR, and steam pressure sat1sfactory given by the comb1nation of BPL and BPB. Th1s last permission is included to care for the possibility of a steam line break. At start-up, the steam pressure is zero, but 1f while running this pressure returns to zero, it indicates a break and so the reactor must be scrammed. In order to prevent too rapid cooling of the soup, this scram is initiated by 1 trst stopping circulation. When starting vith low bo1ler pressure, PS-3 is open and BPL is de-energ1zed, so contacts BPL-C are closed and relay BPB may be closed by PB-6 and will lock 1n. Thus the soup c1rculating pump has permission through contacts BPB-C. As the reactor comes up to power and steam pressure builds up in the system, PS-3 closes, thus dropp1ng out BPB through contacts BPL-C. However, contacts BPL-A now permit the soup pump to cont1nuie to operate. If a steam line breaks the steam pressure drops, relay BPB drops out and both contacts BPL-A and BPB-C are now open, and the c1rculating pump stops, initiating a scram, as discussed below.

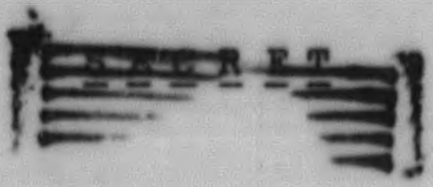

$-96-$

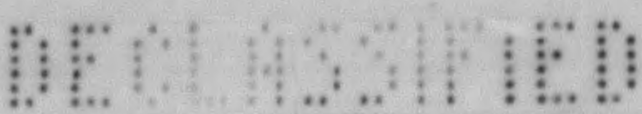


To reduce the number of unnecessary scram possibilities, the circulatIng pump motor is not automatically protected against over temperature or lack of cooling o11. However, the cooling o11 pump atarts from the same switch as the circulating pump, subject to water pressure on the o1l cooler, and improper values of o11 pressure give an alarm. It 1s believed that these alarms are preferrable to the system of automatic protection since a false signal in the automatic system would stop the punp and thereby shut the reactor down completely.

The soup may now be brought to the desired operating temperatur: by passing steam through the water side of the beat exchanger. This process is a straightforward one of setting up the correct valves for the source of steam to be used and Involves no safety interlocks.

Meanwhile, the reflector may be brought up to cperating level. This operation is now permitted by the soup up relay contacts FFR-A, c1rculating relay contacts FCP-D, recombiner 1 gnition on contacts PS-10, and the safety rod relay contacts PIC $-\mathrm{A}$ and PIU-A. The "Test-Run" switch, S-6, must be in the "Run" position for regular start-up so contacts $86-1$ are closed. The two pulsafeeder pumps may be started by the respect1ve motor start switch and pushbutton. They now run under control of the reflector level instrument, LRC-12, through relay DFU and DFA. Relay DFA 18 controlled by the "almost full" contact, RS-2 of LRC-12, picking up when the level reaches this value. DFU 1s controlled In a similar manner by the "ful1" contact, RS-1. When the pumps f1rst start, these contacts are open and both relays de-energized so contacts DFA-A, DFU-B, and DFU-D are ell closed. The holding contacts, DP1-A and DP2-B, of the motor relays close when the motors are started. As the level comes up, relay DFA p1cks

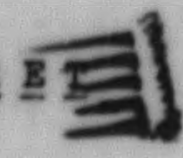


up, opening contacts DFA-A, but the motor relay is held in by contacts DPI-A. At full level, relay DFU p1cks up and stops both pumps. Pump 2 will not restart unless its start button is again pressed, so it is effectively removed from 1nstrument control as soon as the reflector is up. It is completely blocked when the "Start-Run" switch is thrown to "Run," opening contacts 55-5. Pump 1 1s silil on instrument control since its starting switch is not a spring return type. Th1s pump w11l therefore start each time the level arops to the "almost full" point, and stop when the level reaches the "full" value. Switch s-11 provides a manual means of "inching" the level for certain experiments. While It is not a part of the safety circuit, it may be noted that instrument LRC-12 operates the let-down valve 155 to bleed off $\mathrm{D}_{2} \mathrm{O}$ if the level is too high. Thus, if the operator whes to operate with a lower reflector, he merely changes the control point of the instrument and the excess $D_{2} \mathrm{O}$ is bled off and the pumps function to maintain level at the new value.

If operational experience indicates that the slightly fluctuating level of this scheme is unsatisfactory, or if the let-down val ve leaks excessively, the operation may be readily modifiad to correct the trouble. The control of pump 1 can be changed to keep it operating continuously, and the level maintained by throttling valve 155. The pump would then be subject to instrument shutdown only If the level exceeded a safe upper limit, set slightly above the control point of valve 155 .

As soon as the reflector level has reached the half-full velue, the interlock on the helium valve, 276B, is released so helium can be supplied for pressurizing the reflector. Thus, as the pulsafeeder pumps fill the reflector, 


\begin{abstract}
will scram the reactor. The reactor may be brought all the way to power with concentration control, or the rinal stage may be done vith the rods. For safety It is recommended that the rods be used so they w11l be up and can serve as additional safety rods. Fine concentration control is obtained by thrott1ing valve 126.
\end{abstract}

When the concentration has reached the desired value, the rods may be raised to further increase reactivity. of course, the rods may be raised before concentrating to the final value and the reactor then brought to the deafred level with concentration control. It is believed that this is the safer method. A suttch on the concentration valve controls relay FCV so the shim and control rode cannot be raised while the fuel is being concentrated.

As the reactor is brought up in power a point is reached when heat no longer needs to be supplied from the steam to maintaln soup temperature, and actually a steam load must be extracted to prevent overheating. At this change over it is important that there be no sudden coolinis of the soup (and hence increase of reactivity) by the admission of feed water to the heat exchanger. At least two procedures suggest themselves. The first is to close the arain valve and very slowly $f 111$ the heat exchanger from the feed vater pumps by gradually increasing the control point of LIC-8. W1th steam still supplied and soup clrculating through the exchanger, this ehould result in the water being heated to almost steam temperature as it is admitted, and thus cause no appreciable change of soup temperature. The second method is to close the drain valve and allow the condensate to $f 111$ the heat exchanger. With some operating experience the operator should be able to estimate when the drain valve should 


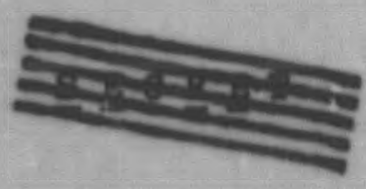

be closed to have sufficient water when the reactor starts delivering power. In any event, the control point of LIC-8 should correspond to the level of condensate when the feed water pumps are started and the instrument is alLowed to take over control. The second method is probably the safer from the standpoint of sudden temperature changes, but elther should be entirely satisfactory if the operator exercises normal care.

The reactor may be shutdown or reduced in power, at the option of the operator, by means of any of the reactivity controls. It may be shutdown automatically by any of several emergency conditions, as indicated in Figure 26 and detalled in F1gure 27.

In general, a reduction by the operator in the operating level will be by rods or concentration for fine control, and by reflector level for large shim control. The rods may be manipulated to reach a new power level without any restrictions other than the requirement that only one reactivity control is increasing reactivity at a given moment. To reduce resctivity by dilution of the fuel the concentration valve and the dilution valve are both opened, thereby stopping the collection of condensate and feeding vater from the condensate tanks to the core. The reflector shimming action is controlled by varying the control point of the level controller, LRC-12. The pulsafeeder pump control contacts and the let-down valve control function at any setting of the control point, so the operator merely changes the point and the instrument does the rest.

There are several methods avallable to the operator for shutting the reactor down, and various combinations of these could be used. However, all 
of these do not make restarting equally easy. For an emergency calling for quick shutdown, the rods are dropped and will be followed automatically by a reflector dump. If the emergency involves the soup system, the operator may dump the soup by operating the soup dump switch, s-9. Reflector may be dumped by switch s-7.

For a routine shutdown, it is suggested that the fuel be diluted to a value which will make the reactor sub-critical at room temperature. This operation will require about seven minutes with the dilute valve wide open. The rods are then run down and the reflector allowed to dump. Th1s leaves the reactor in an "ever-safe" condition with the soup in the core system. Bxperlence may indicate that this procedure may be modified; for example, complete dilution of the soup may not be necessary, and thus the concentration time at start-up may be shortened. In this event, the operator must realize that the reactor may become critical as the reflector is raised, so the necessary care must be exercised in raising the reflector. When the reactor is to be down for a long period, it is probably preferable to dump the soup as vell as the replector.

There are several interlocks on the shutdown devices. Whenever the safety rod leaves the cocked position, whether by drop or run-down, the reflector timer is started by the clutch or upper 11mit switch: After a definite time Interval, presently consicered as 30 seconds, the timer opens the $D_{2} 0$ dump valve. During the time delay interval, the operator may block tae reflector dump by means or the "hold dump" switch, s-8. Th1s feature 1s provided so the operator may survey the situation when the rods are dropped, and if he finds the drop

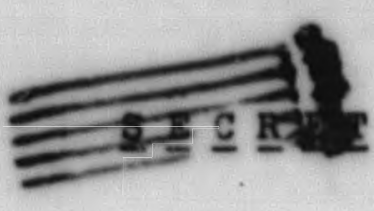


contactor, so loss of motor voltage for any reason operates relay FIR and causes a dump. This feature must be blocked during initial filling so contacts of the "start-run" switch, S-5, are connected in the circult of relay FIR. An adaitional interlock on the soup dump is provided to open the dilution valve and thus reduce the concentration to a safe value for the next start-up.

The monitrons, QRC 24 and 56, which detect abnurmal activity in the shleld also stop the stack fan, leaving the shield under stack draft only so an' excessive amount of activity w111 not be pessed up the stack.

The safety and shim rod magnets are tripped by many emergency signals. The normal safety and period trips are provided through the sigms bus of the amplifiers so dangerous nuclear conditions can initiate a scram without the delay associated with mechanical relays. Less critical conditions open the magnet amplifier power supply. Contacts RS-9 on the counting rate meter prevent a start-up without an adequate source. Low vater or, air pressure drops the rods through pressure sw1tches PS-11 and PS-12. Because of the start-up safety 1nterlocks, the rode should be dropped whenever the reflector is dumped. Th1s 18 provided for by switch $57-2$ and reley contact FDD-B. The various monitrons function through the contacts shown as 23-D, 24-D, 25-D, 26-D, and 68-D.

\section{A "test-run" switch is provided so the rods or reflector may be tested} when conditions are safe. The reactor cannot go critical when the reflector is down so the rod motors can be energized through $56-4,1 f$ the reflector low level contácts, DLL-B, Ina1cate an empty reflector. The reflector pumps may be operated at will if the core 18 empty. This conditions is given by the "reflector test" position of s-6 when contacts s6-2 energize the pump motor c1rcuits and

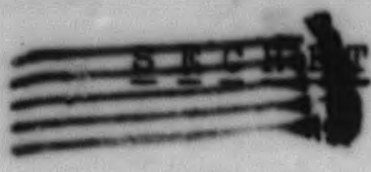

$-104-$

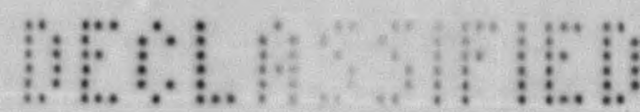




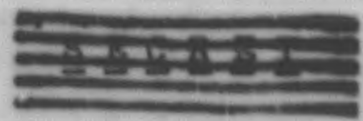

s6-1 opens the dump valves.

\section{Operation and Loading of the Generator}

Under normal conditions the reactor is loaded by operating the turbogenerator on the TVA system. The characteristic behavior of an alternator operated in parallel with a fixed frequency and voltage system maikes load control rather simple. With this connection' the frequency of the alternator, and hence 1ts speed, cannot change, so the only way its load can be altered is by changing the setting of the governor. Contrary to the case of d.c. generators operated In parallel, changing the generator fleld does not change its load. Rather, a change of field produces a change of Induced voltage which permits a circulating component of current to flow, wh1ch in turn adjusts the terminal voltage of the alternator to that of the f1xed syetem. The net effect of this is a change in alternator power factor. There is a small change of delivered pover due to a change in alternator resistance loss with the new current, but this load change is completely negligible. Thus, once the generator is synchronized on the Iine Its load is adjusted by adjusting the turblne governor by means of the governor control on the console. The power factor 18 adjusted with the field rheostat on the console, or for extreme variation 1t may be necessary to use the fleld rheostat on the panel board. Normal power factor w11l be unfty.

The turbine $1 \mathrm{~s}$ brought up to speed gradually by admitting steam slowly through the appropriate valve from e1ther the house supply or the reactor. The speed of the turbine is indiceted on the frequency meter, 60 cycles representan. Ing rated speed. Por normal operation the governor should be set by the governor control switch to give rated speed with the steam valve fully open. If the 
turbine is operating from one steam source and it is desired to transfer to the other, this may be done by opening the valve in the line to the second supply and closing that to the first, the check valve in the building steam ilne preventIng any back-up of reactor steam 1nto the bu1laing system.

pfter the turbine is varmed up the generator may be synchronf zed on the 1ine by standard procedures. The synchroscope is turned on by the switch on the panel board. Output voltage of the alternator is adjusted to the 1 ine value, these being Indicated by alternator and line voltmeters, by the fleld rheostat on the console. The turbine governor is sdjusted so the synchroscope rotates very slowly. (This rotation should be slow enough to permit the operator to close the c1rcuit breaker before the machine can get out of synchronism.) If the frequency is 1nitially very far from correct it is easier to adjust the speed approximately oy using the frequency meter as an indicator. W1th the alternator and line voltages equal and the synchroscope rotating very slowly, preferably with the local frequency above TVA frequency (synchroscope rotating in the "fast" direction), the generator breaker should be closed as the synchroscope goes through the synchronous position. Practically, th1s means the operator should throw the breaker switch just before synchroscope pointer reaches the vertical position, so the breaker will actually close as the pointer goes through the vertical position. If the generator and line voltages are too far out of synchronism the rush of current when the breaker closes w11l immediately trip it out and at the same t1me subject the alternator to undesirable stress.

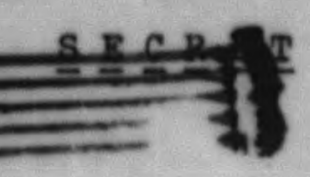

$-106-$

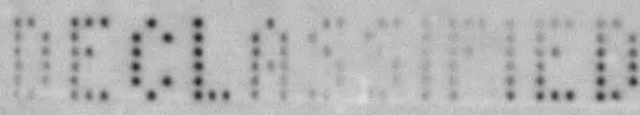




\section{Conclusion}

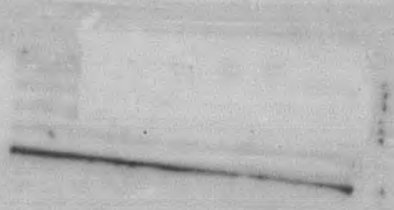

Th1s report has been prepared before the reactor desige and construction are completed and it is expected that some minor modifications in Instruments and controls will be necessitated as the work progresses. These w11 be covered in later reports or in a supplement to this report. Finished control dravings are not yet avallable, but will be 1ssued as series Q-1139 for nuclear and safety c1rcuits, and Q-1220, Q-1221, Q-1222, \&-1223, and Q-1224 for process 1nstruments and 1nstallations.

The work covered by this report is the result of valuable contributions by many people on the Laboratory stafe. While individuel acknowledgment of each contribution is not practicable, a major portion of the work was done by L. P. Ing11s, C. A. Mossman, J. B. Owens, and B. P. White.

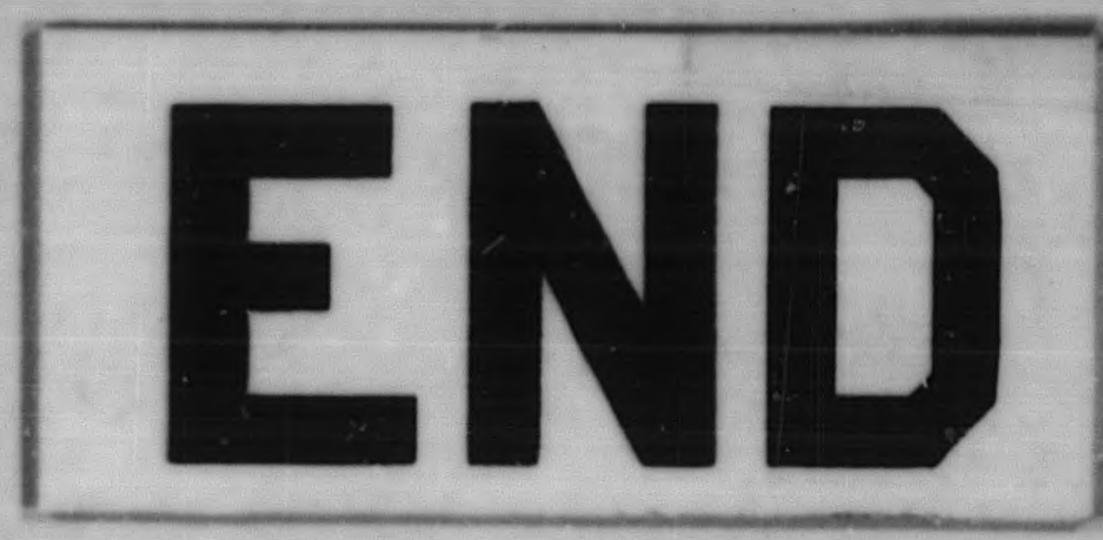

$-107-$

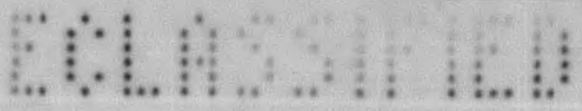

